Andrews University

Digital Commons @ Andrews University

Professional Dissertations DMin

Graduate Research

1998

\title{
A Strategy for Public Evangelism in Russia
}

Mikhail K. Morar

Andrews University

Follow this and additional works at: https://digitalcommons.andrews.edu/dmin

Part of the Practical Theology Commons

\section{Recommended Citation}

Morar, Mikhail K., "A Strategy for Public Evangelism in Russia" (1998). Professional Dissertations DMin. 710.

https://dx.doi.org/10.32597/dmin/710

https://digitalcommons.andrews.edu/dmin/710

This Project Report is brought to you for free and open access by the Graduate Research at Digital Commons @ Andrews University. It has been accepted for inclusion in Professional Dissertations DMin by an authorized administrator of Digital Commons @ Andrews University. For more information, please contact repository@andrews.edu. 
ABSTRACT

A STRATEGY FOR PUBLIC EVANGELISM IN RUSSIA

by

Mikhail K. Morar

Adviser: Bruce L. Bauer 


\title{
ABSTRACT OF GRADUATE STUDENT RESEARCH \\ Dissertation

\author{
Andrews University \\ Seventh-day Adventist Theological Seminary
}

\begin{abstract}
Title: A STRATEGY FOR PUBLIC EVANGELISM IN RUSSIA
Name of researcher: Mikhail K. Morar

Name and degree of faculty adviser: Bruce L. Bauer, D. Miss.

Date completed: July 1998.
\end{abstract}

Problem

After Perestroika ushered in new opportunities for public evangelism in Russia, local and foreign evangelists have been baptizing thousands of new converts every year. The rapid growth resulting from these crusades has brought about new challenges. This study analyzes some of the challenges associated with public evangelism in Russia and suggests a strategy to improve the longterm results of these campaigns.

\section{Method}

A descriptive analysis of John Carter's 1992 evangelistic campaign in Nizhniy Novgorod city was conducted in order to suggest ways to improve long-term results from public campaigns. The strengths and weaknesses of evangelistic campaigns in Russia 
are discussed.. A practical strategy for conducting public evangelism in Russia is clearly presented which covers the preevangelism phase, the conducting of the crusade, and the postevangelism phase.

\section{Results}

The socio-political conditions which prevailed in Communist-dominated Russia made public evangelism an inappropriate method of evangelism until 1989. After the dismantling of Communism unlimited doors for public evangelism in Russia were opened. Today public evangelism is the major source of church growth in Russia.

A major problem facing Russian evangelists, however, is a high attrition rate among new members. Several factors have contributed to this. First, there was little effort among Russian pastors toward building a proper concept of evangelism among members. Furthermore, most members were mere spectators while the local pastors and conference officials dominated the crusade management. Therefore, evangelists need to ensure that the local church is empowered to make the crusade their own.

Evangelists have a tendency towards preoccupation with the actual conducting of the crusade while neglecting pre- and postevangelism phases. Obstacles to success during the preevangelism phase include misallocation of resources, lack of entry events, and failure to draw up action plans. The conducting of the crusade is often hampered by the lack of a 
system for distributing incentives and neglecting various cultural factors. The greatest need, however, is for a properly planned and funded follow-up phase. The biblical model of discipling has not been implemented and churches are failing to assimilate thousands of new members.

\section{Conclusion}

The purpose of this paper is to suggest a strategy for public evangelism in Russia in order to meet the needs of the pre-evangelism, the evangelism, and the post-evangelism phases of public crusades. Each evangelist, whether local or foreign, should give adequate priority to follow-up plans even before the crusade begins, and properly meet the many needs of spiritually mature members as well as new members. 
Andrews University

Seventh-day Adventist Theological Seminary

A STRATEGY FOR PUBLIC EVANGELISM IN RUSSIA

A Dissertation

Presented in Partial Fulfillment

of the Requirements for the Degree

Doctor of Ministry

by

Mikhail K. Morar

November 1998 


\section{A STRATEGY FOR PUBLIC EVANGELISM IN RUSSIA}

A dissertation

presented in partial fulfillment

of the requirements for the degree

Doctor of Ministry

by

Michael K. Morar

APPROVAL BY THE COMMITTEE:

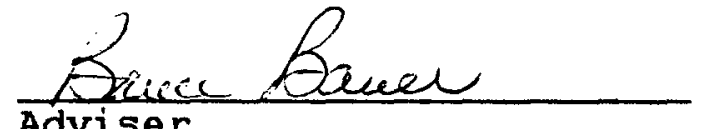

Adviser,

Bruce Bauer
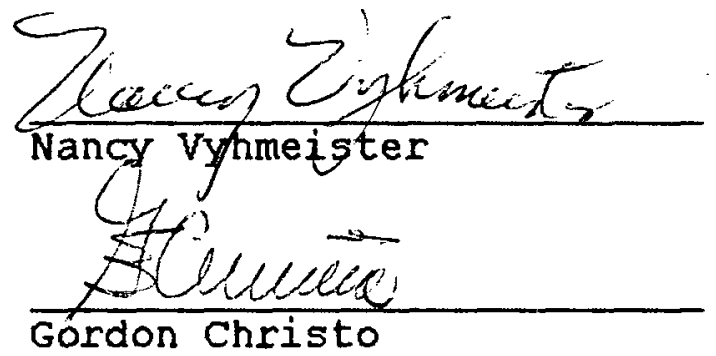

Micoudo Anton Director of D.Min. Program Ricardo Norton

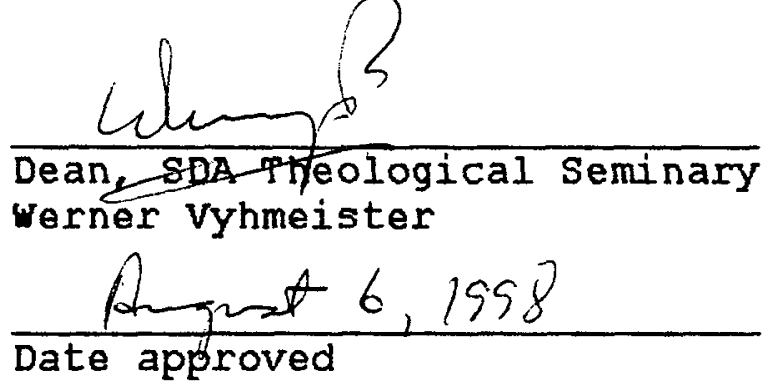


Natalia

Loving wife and mother of my daughter Annushka, sons Konstantin and Ellijah, faithful helpmate and devoted Christian. 
TABLE OF CONTENTS

LIST OF TABLES

viii

Chapter

1. INTRODUCTION . . . . . . . . . . . . . . . . . . . . . . . . 1

Purpose . . . . . . . . . . . . . . . . . . . . . 1

Justification . . . . . . . . . . . . . . . . . . . . 1

Methodology . . . . . . . . . . . . . . . . 5

2. POLITICAL SITUATION AND CHRISTIANITY IN THE FORMER

USSR AND PRESENT RUSSIA . . . . . . . . . . . . . . . . . . 7

Russia . . . . . . . . . . . . . . . . . . . . . 7

Christianity in Russia . . . . . . . . . . . . . . . . . 9

Church and State in Russia Today . . . . . . . . . . . 14

Relationship Between SDAs and the Orthodox Church . . 19

Development of SDA Evangelism in Russia . . . . . . . 21

Evangelism in Russia, 1880-1917 . . . . . . . . . 22

Evangelism, 1917-1985 .. . . . . . . . . . 29

Evangelism, 1985 to Present . . . . . . . . . 36

Zaokski Theological Seminary . . . . . . . . . . 39

Soviet officials Visit the General

Conference.................. . 40

Innovations in Evangelism . . . . . . . . . . . 44

Public Evangelism Explosion . . . . . . . . . . 48

Public Evangelism and Church Growth . . . . . 54

3. DESCRIPTION, ANALYSIS, AND EVALUATION OF JOHN CARTER'S

1992 CRUSADE

Description of Nizhniy Novgorod . . . . . . . . . . 59

History . . . . . . . . . . . . . . . . . . 60

Economy . . . . . . . . . . . . . . . . . . . . 60

Population, Language, and Culture . . . . . . 61

Education . . . . . . . . . . . . . . . . . 62

The SDA Church in Nizhniy Novgorod . . . . . . . . . . 62

Public Evangelism Explosion . . . . . . . . . . 64

Church Growth . . . . . . . . . . . . . . . 65

Mass Media Evangelism .. . . . . . . . . . 66

Description of Carter's Crusade . . . . . . . . . . 66

The Evangelist . . . . . . . . . . . . 66 
How It All Began . . . . . . . . . . . . . . . . . 67

Timing of Carter's Crusade . . . . . . . . . . . 70

Preparation and Organization . . . . . . . . . . . 71

Prayer Groups . . . . . . . . . . . . . . . . . 74

Advertising . . . . . . . . . . . . . . . . . . 77

Entry Events.................. 80

The Crusade . . . . . . . . . . . . . . . . 80

First Day . . . . . . . . . . . . . . . . . . . 81

Daily Crusade Program . . . . . . . . . . . . . 84

A Cultural Aspect . . . . . . . . . . . . . . . 84

Sermons . . . . . . . . . . . . . . . . . . . . 85

Seating Arrangement . . . . . . . . . . . . 86

Distribution of Literature . . . . . . . . . . . 87

Baptism . . . . . . . . . . . . . . . . 87

Church Planting . . . . . . . . . . . . . 88

Follow-up Plans . . . . . . . . . . . . . . . . 89

Analysis of Long-Term Results . . . . . . . . . . . . 89

The Theoretical Basis of Analysis . . . . . . . . 90

Analysis of Pre-Evangelism Phase . . . . . . . . . 93

Analysis of Public Meetings . . . . . . . . . . . 98

Visitation Program . . . . . . . . . . . 103

Music . . . . . . . . . . . . . . . . . . 104

Seating Arrangement . . . . . . . . . . 105

Field School . . . . . . . . . . . . . 106

Time Constraints. . . . . . . . . . . . 106

Baptismal Arrangements . . . . . . . . . . . . 106

Churches Planted . . . . . . . . . . . . 108

Analysis of Dropout Factors . . . . . . . . . . 109

4. DEVELOPMENT OF AN IMPROVED STRATEGY FOR PUBLIC

EVANGELISM IN RUSSIA . . . . . . . . . . . . . . . . . . 115

The Concept of Evangelism . . . . . . . . . . . . . . 115

Ellen White's Concept of Evangelism and

Adventist History . . . . . . . . . . . . . . . 115

Drawbacks to the Traditional Concept of

Evangelism . . . . . . . . . . . . . . . . . 118

Model Concept of Evangelism for Russia . . . . . . 119

Perception of Public Evangelism in Russia . . . . . . 125

Planning for Evangelism . . . . . . . . . . . . . 128

Revival First Step . . . . . . . . . . . . . . . . . . 129

Formation of Committees . . . . . . . . . . 133

Meeting the Board . . . . . . . . . . . . . 133

Action Plan . . . . . . . . . . . . . . . . . 138

Specific Activities (Tasks) . . . . . . . . . 141

Time Frame (Dates) . .. . . . . . . . . . . 142

Persons Responsible . . . . . . . . . . . . 142

Resources and Budget . . . . . . . . . . . . 143

Steps to follow . . . . . . . . . . . . . . . . 143 
Evangelism Committees . . . . . . . . . . . . 144

Finance Committee . . . . . . . . . . . . . . 146

Prayer Groups . . . . . . . . . . . . . . . . . 152

Secretarial Team . . . . . . . . . . . . . 155

Usher Committee . . . . . . . . . . . . . 156

Public Relations Committee . . . . . . . . . 157

Transportation Committee . . . . . . . . . . 159

Supplies/Materials Committee . . . . . . . . . 160

Visitation Committee . . . . . . . . . . . . . 160

Music Committee . . . . . . . . . . . . 161

Food Committee . . . . . . . . . . . . . . . . 164

Equipment Committee . . . . . . . . . . . . . 165

Committee for the Handicapped . . . . . . . . 166

Telephone Evangelism Committee . . . . . . . 168

Security Committee . . . . . . . . . . . . . . . 169

Platform Committee . . . . . . . . . . . . 170

Bookstand Committee . . . . . . . . . . . 170

Children's Ministries Committee . . . . . . . 170

Health Committee . . . . . . . . . . . . . 172

Baptism Committee . . . . . . . . . . . . . . 173

Family Enrichment Committee . . . . . . . . 173

Community Survey Committee . . . . . . . . . . . 174

Crusade Coordinating Committee. . . . . . . . 175

Follow-up Committee . . . . . . . . . . 176

Entry Events. . . . . . . . . . . . . . . . . . 178

Advertising . . . . . . . . . . . . . . . . . . . 179

Television Advertising . . . . . . . . . . . . 180

Radio Advertising . . . . . . . . . . . . . . . . 181

Personal Invitations . . . . . . . . . . . . . . 182

Posters . . . . . . . . . . . . . . . . . . 183

Newspapers . . . . . . . . . . . . . . . . 183

Billboards . . . . . . . . . . . . . . . . . . 184

Conducting of Crusade . . . . . . . . . . . . . . 185

Evaluation Seminar with Leaders . . . . . . . 185

Rapport with Local Community . . . . . . . . . 186

Opening Night . . . . . . . . . . . . . . 187

Rehearsal . . . . . . . . . . . . . . 187

Inaugural Program . . . . . . . . . . . . . . . 188

Inconvenience of First Night . . . . . . . . . . 189

Short and Powerful Sermon . . . . . . . . . 189

Evaluation . . . . . . . . . . . . . . . 190

Daily Crusade Program . . . . . . . . . . . . 190

Monitoring and Evaluation . . . . . . . . . . . 192

Visitation During the Crusade . . . . . . . . . 193

Length of Crusade . . . . . . . . . . . . . . . 193

During the Crusade . . . . . . . . . . . . . . . . . . 194

Attendance Incentives . . . . . . . . . . . . . 195

Preparation for Baptism . . . . . . . . . . . . . 196

Timing of Baptismal Classes . . . . . . . . . . 197 
Decentralization of Class Organization . . . . . 199

Use of Incentives in Baptism . . . . . . . . . . . 200

Follow-up . . . . . . . . . . . . . . . . . . 201

Establish Peer Visitation Program . . . . . . . 202

Appoint Selected Laity as

Pastor's Assistants . . . . . . . . . . . . . 202

Continue Regular Meetings with whole

Groups . . . . . . . . . . . . . . . . 203

Organize Cottage Meetings . . . . . . . . . . 204

Organize Youth Ministries . . . . . . . . . . . 205

Church Planting . . . . . . . . . . . . . 207

Church Building . . . . . . . . . . . . . . 208

Establishing a Purpose-Driven Church . . . . . . 210

Cultural Aspects of Evangelism . . . . . . . . . . . . 214

Prayer Posture . . . . . . . . . . . . . . . . . . 214

Criticism of Orthodox Church . . . . . . . . . 215

Wearing of Cross . . . . . . . . . . . . . . . . 216

Special Gowns for Pastors . . . . . . . . . . 217

Respect Religious Celebrations . . . . . . . . 217

The Touring Evangelist . . . . . . . . . . . . . . 218

Evangelist and Translator Relationship . . . . . . 219

Appreciation of Hospitality . . . . . . . . . 219

Cultural Aspect of Sermons . . . . . . . . . . 220

Order and Content of Sermons . . . . . . . . . 221

5. SUMMARY, CONCLUSION, AND RECOMMENDATIONS . . . . . . . . 223

Summary . . . . . . . . . . . . . . . . . 223

Local Church Empowerment . . . . . . . . . . . . 223

Preparation of Baptism Candidates . . . . . . . 224

Conclusion . . . . . . . . . . . . . . . . . . . . . 225

Field Schools . . . . . . . . . . . . . . . . 226

Three Phases of Evangelism . . . . . . . . . 226

During the Pre-evangelism Phase . . . . . . . . 227

During the Crusade . . . . . . . . . . . . . 227

Post-evangelism Phase . . . . . . . . . . . 228

Recommendations . . . . . . . . . . . . . . . 228

Recommendations to the General Conference and

Division Ministerial Departments . . . . . . . . 230

For Future Study. . . . . . . . . . . . . . . . 231

BIBLIOGRAPHY . . . . . . . . . . . . . . . . . . . . . 233

VITA . . . . . . . . . . . . . . . . . . . . . . . . . . 241 


\section{LIST OF TABLES}

1. The Fifteen Republics of the USSR . . . . . . . . . . . . . 8

2. Religious Groups in Russia . . . . . . . . . . . . . . . 17

3. Church Membership in Russia in the 1916-1985 Period. . . 32

4. Church Membership, East Russian Union Mission, 1994. . . 55

5. Church Membership, West Russian Union Mission, 1994. . . 56

6. Number of Churches, Volga Vatsky Conference, 1994-1996 . 56

7. Membership Growth, Gain, and Loss, Volga Vatsky Conference, 1994-1996 . . . . . . . . . . . . . . . . . 57

8. Sources of Losses, Volga Vatsky Conference, 1994-1996. . 58

9. Nizhniy Novgorod, Growth of Churches and Church Membership .. . . . . . . . . . . . . . . . . 66

10. Perception of Major Points for Better Organization of Crusade . . . . . . . . . . . . . . . . . 93

11. Major Reasons for Backsliding . . . . . . . . . . . 95

12. Findings on Member Dropout . . . . . . . . . . . . . 96

13. Perceptions of Public Evangelistic Crusades . . . . . . 127 


\section{CHAPTER I}

\section{INTRODUCTION}

\section{Purpose}

The purpose of this study was to develop a strategy for public evangelism in Russia which takes seriously the retention of newly baptized members.

\section{Justification}

Several problems have accompanied Seventh-day Adventist (SDA) public evangelistic campaigns in the former USSR during the last decade. Each of these problems contributes to the need for this study and demands resolution in the strategy designed.

For seventy years Russia was closed to the outside world and Russian Christians had no Bibles. Most foreign evangelists who came to Russia after 1990 brought not only their strategies, but also trained local Russians to use their imported strategies. It is important to discover whether these strategies are appropriate to the cultural realities of a community isolated for seventy years without the Bible.

Since the early 1990s the Russian Seventh-day Adventist Church has been using the so-called "old" Western method of public evangelism, which was very new to Russia: short-term 
crusade (22-26 days), without field preparation, with sermons on doctrinal teachings, without a follow-up program after baptism. Public evangelists seem to have been preoccupied with large numbers of baptisms. The importation of foreign evangelists and new evangelistic methods and approaches has also raised questions about cultural appropriateness. Have the evangelists who came to Russia taken into account the cultural environment?

Several incidents in Russian evangelistic crusades have. highlighted the need to develop a strategy to correct these problems. For example, because of negligence, invitations and posters were not printed or were not distributed. Thousands of dollars were thus lost. Foreign evangelists who were affected by such negligence were not informed.

Few foreign evangelists are aware of the fact that, in Russia, public evangelistic crusades are conducted from beginning to end without the involvement of the local church members except for some participation by a few members in the evenings during the actual crusade. Either ignorantly or deliberately, several local pastors have not encouraged the local church to become directly involved during the pre-evangelism and post-evangelism phases. In a few instances the so-called "local crusade committee" is nothing more than a few handpicked members put together by the pastors.

The baptismal service is the climax of most public evangelistic crusades in Russia. At some baptismal ceremonies, 
evangelists have offered incentives to those being baptized. The seemingly simple and innocent act of giving Bibles to candidates upon baptism has contributed to distorted baptismal statistics. The high value placed on the Russian Bible has led some be baptized repeatedly so as to get an additional Bible at each baptism. With twenty or thirty pastors baptizing during a single ceremony and over one thousand people queuing for baptism, there is ample opportunity for such deception. Evangelists, especially foreign ones, have not been aware of this problem. As a result, the number of reported baptisms in major crusades held between 1990 and 1995 may appear larger than it really was.

After baptizing the new members, most evangelists have relied heavily on the local church pastors to design and implement an effective follow-up plan. This strategy has not worked well in Russia. Placing the responsibility for the follow-up program on the local church pastor is expecting more than most pastors can deliver. The majority of Russian pastors are laypersons with little seminary training. Their pastoral skills are based on hands-on experience, but most are lacking the ability to design and implement an effective follow-up plan. Coupled with this, the new churches are too large, with some having one thousand or more new members added at the end of the crusade. It is impractical to expect one pastor to provide nurturing for so many new people.

The recent crusades have resulted in thousands of new 
members joining the baptismal classes. The evangelist faces several logistic problems regarding these classes. Space for the classes to meet is a problem; a shortage of persons who will teach the baptismal classes is another. The greatest problem is finding time for the classes to meet because the classes are conducted while the crusade is still running. Most foreign evangelists are accompanied by a large group of volunteers, but language barriers limit their usefulness.

Some evangelists have faithfully followed the traditional list of SDA public evangelistic sermon topics. This may be appropriate for countries where the majority of the audience comes from a Protestant background or has had wide exposure to the Bible. However, this is not the case in Russia, which has had no exposure to the Bible for seventy years. Evangelists tend to overemphasize doctrines at the expense of preaching, not just Christ-centered sermons, but preaching about Christ.

Cultural factors are important in public evangelism, and yet some evangelists have displayed total disregard for the Russian culture. The acceptable prayer posture is disregarded, much to the frustration of the audience. Some evangelists have used the pulpit to openly criticize some of the revered religious ceremonies such as Easter and Christmas. Other evangelists, accompanied by their family, have displayed cultural insensitivity in the way they relate to each other.

Public evangelistic crusades have been the main cause of an 
explosion in church growth in.Russia from 1990 to the present. At the same time, the rate of apostasies has grown dramatically.

\section{Methodology}

In order to design an appropriate evangelistic strategy for use in Russia, literature on evangelism was carefully examined. Personal experience from many evangelistic campaigns was heavily drawn upon, including my experience in John Carter's crusade.

Chapter 1 presents the purpose of this study. The major problems that make this study important are also outlined.

Chapter 2 discusses the social, cultural, political, and religious settings in Russia, former USSR, and present Russia, and why these factors must be taken into account when doing evangelism. The development of evangelism is also traced from the early inception of the SDA church to the current age of public evangelism in Russia.

The impact of pubiic evangelism on church growth since 1990 is illustrated with special attention being directed at the problems of apostasy.

Chapter 3 describes, evaluates, and analyzes John Carter's 1992 evangelistic crusade in the city of Nizhniy Novgorod. A brief description of the city is given. The history of the SDA church in Nizhiny Novgorod, as well as present church-growth trends in the region, is presented. The analysis presented focuses on long-term results of the crusade with a special focus 
on those factors that contribute to large numbers of people leaving the church.

Chapter 4 is the climax of the study; it develops a strategy for public evangelism. The concept of evangelism and the perception of public evangelistic crusades by Russian SDA members and pastors are also given in this chapter.

Chapter 5 contains a summary of the study. It also presents the conclusions and recommendations drawn from this research. 


\section{CHAPTER II}

POLITICAL SITUATION AND CHRISTIANITY IN THE

FORMER USSR AND PRESENT RUSSIA

This chapter describes the cultural, political, and religious background of Russia: ${ }^{1}$ This is done to provide a background for the history of SDA evangelism.

\section{Russia}

At the end of the nineteenth century Russia stretched "over nine thousand miles from east to west" and was said to be "the largest empire in the world," with a population of more than "one hundred million." ${ }^{2}$ In 1923 Russia was renamed the Union of Soviet Socialist Republics (USSR) in fulfillment of Stalin's ambitions to solve the nationality problems in the country. Originally only four republics formed the USSR: Ukraine, white Russia, Russia, and the Transcaucasian Soviet Federated Socialist Republic, composed of Georgia, Armenia, and Azerbaijan.

${ }^{1}$ This chapter presents only those features of Russia essential for understanding the modes of evangelism and development of public evangelism.

${ }^{2}$ L. R. Conradi, "A Visit to Russia," in Historical Sketches of the Foreign Missions of the Seventh-day Adventists (Basle: Imprimerie Polygotte, 1886), 250. 
Fifteen republics made up the USSR; their name and the area they cover are given in table. 1 .

TABLE 1

THE FIFTEEN REPUBLICS OF THE USSR

\begin{tabular}{|c|c|}
\hline Republics & Square Miles \\
\hline Russia & $5,593,909$ \\
\hline The Ukraine & 232,604 \\
\hline White Russia (Belorussia) & 80,154 \\
\hline Armenia & 11,506 \\
\hline Georgia & 29,498 \\
\hline Azerbaijan & 33,089 \\
\hline Uzbekistan & 156,640 \\
\hline Kazakhastan & 62,242 \\
\hline Turkmenistan & 187,181 \\
\hline Tadzikistan & 54,826 \\
\hline Kirghizia & 76,718 \\
\hline Moldavia & 13,050 \\
\hline Lithuania & 25,174 \\
\hline Latvia & 24,903 \\
\hline Estonia & 17,413 \\
\hline
\end{tabular}

Some unique features of the USSR are summed up by Rieber and Nelson:

Again in theory only, all the major and several of the smaller ethnic groups have their own national republic and enjoy legal and political autonomy. The USSR is made up of fifteen Soviet republics, in addition to numerous 
autonomous republics, regions, and national districts, which in theory enjoy certain cultural and political rights. In fact, both the Ukranian and Byelorussian republics send representatives to the United Nations as sovereign powers. ${ }^{1}$

The socioeconomic and political extremes that characterized the USSR created a situation which led Winston Churchill to describe it as "a riddle wrapped in a mystery inside an enigma." ${ }^{2}$

\section{Christianity in Russia}

Russia as a nation embraced Christianity in A.D. 988. Before that time the Russian people were mostly pagan nomads.

When Russian Emperor Vladimir accepted Christianity, he declared Christianity as the official religion of both the princely house and the whole of the Russian people. ${ }^{3}$ This decision by vladimir was made after studying carefully and interviewing religious missions of different faiths and churches including Roman Catholics, Jews, Mohammedans, and the Greek philosophers of the orthodox faith. Vladimir sent emissaries to Saint Sophia in Constantinople; their report led to his conversion and baptism into the Orthodox Church. ${ }^{4}$ The

${ }^{1}$ Alfred J. Rieber and Robert C. Nelson, A Study of the USSR and Communism: An Historical Approach (Chicago: Scott, Foresman and Company, 1962), 24-25.

${ }^{2}$ Alf Lohne, Adventists in Russia (Hagerstown, MD: Review Herald and Publishing Association, 1987), 7.

${ }^{3}$ George Vernadsky, A History of Russia. (New Haven; CT: Yale University Press, 1929), 37-38.

${ }^{4}$ Ibid., 38 . 
declaration of Orthodoxy as the official religion determined the future cultural and political development of Russia and led to the "mass christening of his subjects, building of churches upon former places of pagan worship, legalizing the position of the church, the collection of church tithe, and even the institution of church courts."1

The mass conversion of Russia into the Orthodox or Greek form of Christianity brought about striking results. John Gunther points out how the Greek Orthodox Church affected Russian culture:

For centuries, the unity of Church and Czar dominated Russia. The Greek Orthodox faith, with its sinuous theology, emphasis on dogma, and ceremonial orthodoxy, gave a unique pattern to Russian affairs and attitudes, and not merely in ecclesiastical realms. ${ }^{2}$

In medieval Russia, the Orthodox Church "exercised complete and unchallenged control over the thought and action of the people." 3 Yet the relationship of church and state was not antagonistic during the medieval period.

The popularity of the Church led to its ever-increasing strength so that "it grew strong and rich, and the priests and bishops, especially the Patriarch of Moscow, grew powerful."4

IIbid., 39.

${ }^{2}$ Gunther, 147 .

${ }^{3}$ Vernadsky， 397 .

${ }^{4}$ Lovett Edwards, Russia and Her Neighbors (Oxford: University Press, 1968), 25. 
This led to a situation where there were two power centers, the church and the Czars of Moscow. Eventually when the "Czars became stronger they began to quarrel with the Patriarchs and tried to take power from them." ${ }^{1}$ The privilege that the Orthodox Church enjoyed was greatly curtailed in 1700 by Peter the Great, who believed that the King had supreme authority. Vernadsky points out that

as a result of Peter's church policy, the congregation became merely a section of people living in the vicinity of a given church and possessing no right of selfgovernment in church affairs. ${ }^{2}$

In 1857 the main laws of the Russian empire covered religious aspects such as the following: ${ }^{3}$

1. The Russian Orthodox Church of the eastern wing was dominant over all others:

2. The Emperor could not accept any belief except the teaching of the Russian Orthodox Church. The Emperor, as leader/keeper of the Russian Orthodox Church, must support and defend the faith.

3. Freedom of belief was granted, not only to foreigners and Christian believers, but also to Muslims, Jews, and all peoples in Russia. They were allowed to glorify God in different

${ }^{1}$ Ibid.

${ }^{2}$ Vernadsky, 260 .

${ }^{3} U$. P. Zuev, o Svobode Sovesti, Veroispovedanii $i$ Religioznih objedinenifah (Freedom of conscience, denominations, and religious unions) (Moskva: Mezhdunarodnaya Assotsiatsia Religioznoi Svobodi, Rossiiskoe Otdelenie, 1996), 11-12. 
languages, bless the Czars of Russia, and pray to the universal God to multiply his blessings.

While the government tolerates many creeds, the toleration is somewhat peculiar. Every one is free to practice the religion of his fathers, he can also leave other denominations and join the Greek Church; but woe to the man who tries to leave this church to join another. The Orthodox, the Russians style themselves, are encouraged to proselyte, but if another dares attempt it among them he is liable to be exiled to siberia. The fact that while the state church is ready to receive from all, she gives to none. ${ }^{1}$

The 1905 manifesto of Nicholas II permitted more religious freedom, not only to millions of dissenters but also to the Orthodox Church itself. ${ }^{2}$ This same law led to the reorganization of the church and its missions.

The Russian Revolution of 1917 had a great impact on religious liberty. Communism led the country to break with religion; Russia was the first and only Christian country to take such a step. By 1918 the constitution provided for the separation of state and church, as well as of school and church. ${ }^{3}$ The following were key elements in that constitution.

1. Punishment for religious reasons was prohibited.

2. People were free to follow any type of religion or not to follow any at all.

\footnotetext{
${ }^{1}$ Ibid., 19.

${ }^{2}$ Ibid

${ }^{3}$ Ibid. , 28 .
} 
3. No institution, governmental or otherwise, on Russian territory should perform any religious ceremonies or follow religious rules.

4. No one should neglect to fulfill any duty as a citizen of state because of religion.

5. Schools were to be separate from the church.

6. Teaching children any kind of belief in government or private schools was forbidden.

7. The church had no legal right to own property, for all property belonged to the state.

Reiber and Nelson aptly describe the 1918 constitutional changes:

The church, formerly subsidized by the government, was separated from the state, and freedom of religious and antireligious propaganda was granted. At first antireligious propaganda took the most violent forms. Churches were looted and burned. Priests were attacked. The Militant League of the Godless was formed to fight all religions. ${ }^{1}$

The impact of the 1918 law on religious liberty was in force until Communism fell. Vladimir Lenin, in his conversation with Kalinin (ca. 1920), pointed out that "it is not enough to destroy religion, but religion needs to be replaced with socialistic ideology." ${ }^{2}$ on another front, the Anti-Religion Publishing House printed 140,200,000 books and pamphlets from

${ }^{1}$ Rieber and Nelson, 108.

${ }^{2} \mathrm{~V}$. Stepanov, Svidetelstvo Obvinenija (The testimony of accusation) (Moskva: Russkoe Knigoizdatelstvo Tovarishestvo, 1993), $3: 44$. 
19.28 to 1940 , so as to destroy religion. ${ }^{1}$

These restrictions in Russia made public evangelism impossible. In the first place the SDA Church was stripped of its right to self-government and this affected its mission. The limited religious freedom did not approve proselytism among Russians. Public evangelism could have invited the wrath not only of the Orthodox Church but also of the state.

\section{Church and State in Russia Today}

After seventy years of Communist efforts to eliminate religion through vigorous repression, restriction, persecution, and manipulation, Russia today guarantees religious freedom. Article 52 of the 1978 Constitution of the Soviet Union guarantees freedom of conscience. Since 1988 this right has been largely observed. ${ }^{2}$

During Mikhail Gorbachev's term in 1988, the Patriarch of Moscow was asked to comment on the relationship between church and state with regard to Article 52. The Patriarch observed that the relationship between state and church was one of goodwill and cited graphic manifestations of these relations:

1. In 1983, the government had responded to the request to return the Holy Danilov Monastery in Moscow to the Orthodox Church.

${ }^{1}$ Ibid. , 110

${ }^{2}$ Robert Ehlers, Fred Schulze, Ann C. Bigelow, and Gordon Livermore, The USSR Today: Perspectives from the Soviet Press (Columbus, $\mathrm{OH}$ : Current Digest of the Soviet Press, 1988), 124 . 
2. In 1987 two monasteries had been turned over to the Russian Orthodox Church (Blessed Virgin Optina Pustyny Monastery in Kaluga District, and the Tolga Monastery).$^{1}$

Responding to a specific question on the relationship between the church and local authorities, the Patriarch's response reflected the cordial relationship between the state and the church:

At present, in conditions of restructuring, there is a definite trend toward positive development in these relations. In a number of areas in our country, however, local congregations and eparchial administrations are still encountering what, in our opinion, are unwarranted aifficulties and delays in the resolution of urgent questions of church life. Among these questions I would single out the existing problem of the registration of Orthodox congregations, which is felt especially in places where they are altogether absent. At the same time, in all fairness I should say that a certain amount of progress was made on this question last year. A total of 16 new Orthodox congregations were registered in various regions of the country. We are glad about that.?

The influence of Gorbachev's Perestroika or the "new democratization" led many non-registered churches to apply for

\footnotetext{
${ }^{1}$ Ibid.

${ }^{2}$ Ibid. , 3 .
} 
registration within the provisions of tre law. ${ }^{1}$

The improved relations between church and state in Russia are reflected in the statistical profile of religious groups in Russia in 1990, reproduced in table $2 .^{2}$ That 56.3 percent of the population claims to be Christians stands in marked contrast to the official Communist claim of only a few years ago that the country was atheist.

Improved church-state relations in Russia have resulted in the Orthodox Church losing ground to the Protestant movement. The impact of "over 6,000 Protestant missions and church-based agencies initiating ministry, delivering aid, support, preaching, evangelizing" ${ }^{3}$. cannot be underestimated. Such massive ministry would not have been possible without improvement in church-state relations.

These missionary agencies came to Russia after 1991, when schools, media, public places, and institutions were opened for presentations of the Gospel. The main thrust of their efforts was public evangelism.

Another evidence of the cordial relationships between church and state in Russia today is in the proliferation of theological seminaries. In 1993, twenty-five Protestant seminaries and Bible

'Johannes Reimer, Operation Soviet Union: How to Pray for 160 People Groups in the USSR. (Fresno, CA: Logos, 1990), 24.

${ }^{2}$ Patrick J. St. G. Johnstone, Operation Russia (London: OM Publishing, 1993), 467.

${ }^{3}$ Ibid. , 469. 
Schools were functioning. The same year thirteen more Protestant seminaries were launched. The Russian Orthodox Church had thirteen seminaries by $1993 .^{1}$

TABLE 2

RELIGIOUS GROUPS IN RUSSIA

\begin{tabular}{lc}
\hline \hline Religious Groups & Percentage \\
\hline Christian & 56.30 \\
Orthodox & 55.00 \\
Catholics & 0.48 \\
Muslims & 8.70 \\
Shamanist/animists & 0.80 \\
Buddhists & 0.60 \\
Hare Krishna & 0.47 \\
Jews & 0.40 \\
Non-religious/other & 32.70 \\
\hline Source: Based on Johnannes Reimer, Operation Soviet Union: How to \\
Pray for 160 People Groups in the U.S.S.R. (Fresno, CA: Logos, \\
\hline 1990), 467.
\end{tabular}

The Russian authorities were committed to the implementation of Article 52 of the Russian constitution, which guaranteed freedom of religious conscience. Russian President Mikhail Gorbachev wrote to all government departments to ensure that all property and buildings of religious organizations were returned. ${ }^{2}$ Today the New Russian Constitution of 1993 guarantees to

${ }^{3}$ Johnstone, 469 .

${ }^{1}$ Zuev, 5253 
every citizen of the Russian Federation freedom of religious liberty, belief, right to confess, worship individually or together with other believers, any type of religion or none. Citizens have the right to practice or propagate their religious beliefs. Conscientious objectors who cannot be soldiers on religious grounds can ask to abstain from serving in the army. ${ }^{1}$ As evidence of the cordial relations between church and state, on June 27, 1996, the President of Russia, Boris Yeltsin, wrote to the SDA Church in Russia that he wanted to have good relations between the Adventist Church and other state organizations. This was his message to the church during its celebration of 110 years of existence in Russia. In 1996, the Chairman of the Russian Duma, V. Zorkaltsev, wrote a congratulatory letter to the SDA. Church to mark the celebration of 110 years of Adventist. Church existence in Russia and noted that the SDAs were co-operating in enhancing religious liberty in Russia. Such bold and, open support by the country's leaders contributed to a willingness to initiate a major public evangelistic thrust.

V. Ignateako, another high-ranking government official, on November 1, 1996, wrote a letter to the SDA Church to congratulate SDAs during their celebration of 110 years of Adventist existence in Russia.

Today there are more open doors in Russia for the sharing of

\footnotetext{
${ }^{1}$ Ibid., 37.
} 
the Gospel than can be entered. Public evangelism is one of the effective modes which the SDA Church can use to take advantage of the opportunities available in Russia.

\section{Relationship Between SDAs and the Orthodox Church}

The SDA Church and the Orthodox Church were equally targeted by the Communist party. During the Soviet years, the following statement by. Johnstone about the conditions in Russia applied to

\section{all groups.}

The Church in Russia was the object of the most severe and sustained persecution of any nation in recent history. Martyrs could be numbered in millions, 90\% of church buildings were seized or destroyed, structures and ministries emasculated or manipulated, leadership cowed into compliance and compromise, Christians discriminated against, their children harassed and denied education opportunities, and millions consigned to years of imprisonment, exile or psychiatric "treatment." 1

It did not matter at that time whether one was Orthodox or Adventist. All met with the same fate. All faced the same enemy and struggled to defend religious liberty. Due to communistic repression, the Seventh-day Adventist and Orthodox Churches had to form a common front to deal with issues of religious liberty.

The Russian Orthodox Church had no problems being registered as a national organization, but it took several appeals by the General Conference of SDA for the Adventist Church to be

\footnotetext{
'Johnstone, 467-468.
} 
registered. ${ }^{1}$ The priority treatment given by the state to the Orthodox Church reflected its cultural roots. It would have been unreasonable to expect anything different.

Johannes Reimer points out that $" 70$ years of the Soviet rule has left deep marks of distrust among Chrjstians. Distrust almost became the distinguishing feature of the Soviet Christians."2 SDA and Orthodox Church philosophies are worlds apart. The difference offers a scope for distrust.

Although the SDA and Orthodox Churches formerly collaborated on matters of religious liberty; the current SDA evangelistic thrust has caused concern among the orthodox leadership. SDA crusades have received much publicity and the orthodox Church has reacted sharply against such crusades by a Protestant Church. Consequently, the relationship between the SDA and Orthodox churches has been strained.

Orthodox Church leaders have openly carried out campaigns to frustrate the evangelistic work carried out by the SDA Church. In my personal experience, I have noted several techniques that have been used, including: (1) influencing local government leaders to refuse permission for the SDA Church to organize evangelistic crusades; (2) organizing mobs to disrupt meetings conducted by SDA evangelists; (3) pressuring local leaders into

\footnotetext{
${ }^{1}$ B. B. Beach, "The Church Under Communism," Adventist Review, October 9, 1986, 9-10.

${ }^{2}$ Reimer, 24 .
} 
refusing to rent halls for the use of SDAs in their crusades; (4) pressuring decision-makers of such facilities as transport services to cancel contracts for hiring buses for use by the SDA Church in their crusades; (5) writing tracts and circulating them to people warning them not to attend specific crusades organized by the SDA Church; (6) writing articles in newspapers to discredit SDA evangelism. The growing demands for the Russian Orthodox Church hierarchy. to regain its pre-Communist political dominance pose a potential threat to the SDA Church.

\section{Development of SDA Evangelism in Russia}

Christ's commission to His disciples has been the driving force behind all evangelism.

All authority in heaven and on earth has been given to me. Go therefore and make disciples of all nations, baptizing them in the name of the Father and of the Son and of the Holy Spirit, and teaching them to obey everything that I have commanded you. And remember, I am with you always, to the end of the age. (Matt 28:19-20 NRSV)

In Russia, fulfillment of this commission has not been without obstacles. It is also true for Russia as it is anywhere that "there are no sealed doors (for Christianity) anywhere in the world."1 God's people did not have to wait for the obstacles to be cleared because "the weapons of their warfare are not carnal, but mighty through God to the pulling down of strongholds" (2 Cor 10:4).

${ }^{1}$ A. W. Spalding, Origin and History of Seventh-day Adventists (Washington, DC: Review and Herald Publishing Association, 1962), 2:225. 
Evangelism in Russia, 1880-1917

Working in Russia was difficult for the first SDA

evangelists. Arthur Spalding describes the political setting under which the preachers had to work:

Russia under the Czars was a fortress of autocracy. Civil liberties were at a minimum, and religious liberty was circumscribed to the sphere so narrow as to strangle its life. The Greek Church, the Orthodox, dominated religion. And, being wedded with the state, it had power to crush, outwardly at least, all opposition. ${ }^{1}$

Suppression of religious liberty in Russia forced the SDA Church to use tracts on "The Third Angel's Message" as the main method of evangelism during the early years of Adventist history in Russia. ${ }^{2}$ Due to the impact of that printed matter, "the truth had gained a foothold in Russia as early as 1882." ${ }^{3}$ German-Russian immigrants from South Russia (Crimea) to Minnesota and Dakota accepted the third angel's message and later posted tracts back to their friends and relatives in Russia. ${ }^{4}$ Thus in the period between 1882 and 1917 the distribution of tracts was the main mode of evangelism for the Adventist Church. Public evangelistic crusades did not play a role during that period.

${ }^{1}$ Ibid. , 225-226.

${ }^{2}$ A. W. Spalding, Captains of the Host (Washington, DC: Review and Herald Publishing. Association, 1949), 1:538.

${ }^{3}$ J. N. Loughborough, The Great Second Advent Movement Its Rise and Progress (Washington, DC: Review and Herald Publishing Association, 1903), 409.

${ }^{4}$ Spalding, Captains of the Host, 538 . 
Jacob Reiswig felt the need to follow up the tracts and papers sent to Russia and left for Russia in 1883 at his own expense as a self-appointed evangelist. He was an effective worker and became the first Seventh-day Adventist evangelist who carried the third angel's message into Russia.'

Gerhardt Perk, the first Russian-born Adventist believer, was converted through reading the tract, "Third Angel's Message, "2 obtained from his neighbor. Before his baptism Perk worked as an agent of the Bible Society and traveled widely selling Bibles, something which was allowed at that time as long as no preaching was done. Public evangelism was not allowed, since only priests had the right to preach.

The decision to join the SDA Church came after Perk had lost a thousand dollars worth of Bibles and prayed for their recovery. After much prayer and fasting he recovered all the Bibles and also successfully sold them. This divine providence led Perk to decide to become an SDA. ${ }^{3}$

Perk later became the first SDA Russian colporteur. As a church-worker he worked hand-in-hand with missionaries who came to spread the third angel's message in Russia. Fiofel Babienko was another Russian greatly influenced by the silent ministry of the

${ }^{1}$ E. E. Howell, The Great Advent Movement (Washington, DC: Review and Herald Publishing Association, 1935), 170-171.

${ }^{2}$ Ibid.

${ }^{3}$ Spalding, origin and History, $2: 227-228$. 
printed page. In 1876 Babienko lived in Tarasha, Kiev Gubernia (Region), and was an activist for the Orthodox Church. He used to read the Bible during services and often asked the priest to allow him to take the Bible to his home so that he could read more of it as well as read to his neighbors. As he read through the Bible he came across the Sabbath rest and was convinced of the need to keep the Sabbath.' Finally in 1877 he organized his own church which emphasized Bible study. This led to his banishment to the Caucasus. ${ }^{2}$ While in exile Babienko was the first Russian to conduct public evangelism by reading the Bible to neighbors. He was also successful in planting a church, which was unacceptable to the government, so he was further persecuted for his evangelistic work.

L. R. Conradi was another third angel's message evangelist who had an impact on church history in Russia. In 1885 Conradi left America to go and preach in Europe but was persuaded by Perk to labor in Russia where there was need for an evangelist. ${ }^{3}$ Since missionaries were being refused per-mission to enter into Russia, Conradi went in as a printer. ${ }^{4}$

In July 1886, Conradi and Perk organized an SDA Church in

${ }^{1}$ Institut Perevoda Biblii, S Dobroi Vestiu k Svoim Sootechestvennikam (With good news to our compatriots) (Zaokskii: Institut Perevoda Biblii, 1996), 8.

${ }^{2} \mathrm{~V}$. V. Teppone, Iz Istorili Tzerkvi (From history of the church) (Kaliningard: Yantarnij Skaz, 1993), 8, 10-11.

${ }^{3}$ Loughborough, 409 .

${ }^{4}$ Conradi, 250-255. 
Berdebulat. This became the first Seventh-day: Adventist Church in Russia. A total of nineteen people were converted and began to keep the commandments of God and the faith of Jesus. "This first SDA Church was established without public evangelism but as a result of personal evangelism."1 As a result of the preaching, baptism, and Lord's Supper at Berdebulak, both Perk and Conradi were put in prison for proselytizing. ${ }^{2}$ Commenting on the establishment of the Adventist Church in Russia, Conradi wrote:

The Russian mission has been opened. Not without cost, it is true. Dangers and difficulties are still in the way. Imprisonment and persecution threaten the laborer. The preacher is not at liberty to present the message. But as it is God's cause, who can hinder? ${ }^{3}$

In September of 1886, the second small Russian church was organized." This was the beginning of the SDA movement in Russia. The first Russian pastors were Conrad Laubgan and Yakob Klein. ${ }^{5}$

Because of the political situation that faced the church it is not easy to describe the precise picture of the SDA Church in Russia. However, we may say that it grew through personal evangelism. Conradi pointed out that "all over this vast empire the believers are scattered, and through them light circulates." 6

${ }^{1}$ Ibid., 257.

${ }^{2}$ Ibid. , $255-266$.

${ }^{3}$ Ibid. , 271 .

${ }^{4}$ Institut Perevoda Biblii, 11.

${ }^{5}$ Ibid.

${ }^{6}$ Conradi, 271 . 
Even during his short mission in Russia, Conradi observed that "about eighty are already obeying." ${ }^{1}$ Church growth in Russia continued despite repression, but most of the early growth took place among foreigners, especially the Germans who had been induced to come to Russia as skilled laborers. Out of 886 members recorded in 1897 only 100 were Russians. ${ }^{2}$

Work among Russians progressed slowly because foreign pastors were not allowed to proselytize Russians. ${ }^{3}$ There was no possibility of conducting public evangelism. The language barrier was yet another obstacle, as foreign pastors could not speak or understand Russian and most tracts were not available in the Russian language. This lack of tracts in the Russian language further impeded the effectiveness of evangelism in Russia.

As early as 1889 some Russian literature was made available from Switzerland and was carried across to Russia at great risk. ${ }^{4}$ Later a Russian Publishing House was started at Riga. However the publishing house was closed by government order after a government representative had attended several Adventist Conference meetings in 1910 and concluded that "Seventh-day Adventists in Russia have a determined zeal to win souls, but

${ }^{1}$ Ibid.

${ }^{2}$ Institut Perevoda Biblii, 12 .

${ }^{3}$ Spalding, origin and History, 540 .

${ }^{4}$ Howel1, 173 . 
their whole organization is primarily a missionary one, and every member is expected to help forward the work of the third angel's message." 1 This observation by a government representative shows clearly that personal evangelism by all members was the main mode of evangelism.

Closure of the publishing house did not mark the end of the literature ministry in Russia, but indeed boosted literature evangelism. Howell notes that "it was found possible to turn the business over to a private corporation which did our printing at a low rate." ${ }^{2}$

Despite all obstacles encountered, such as political turmoil, persecution, repression, and civil revolutions, the Russian SDA Church grew in the period before 1917.3 Throughout this period before 1917, personal evangelism was the main mode that was used. The greatest obstacle to public evangelism was the Orthodox Church as it sought to repress other denominations in Russia. Persecution was especially targeted at the protestant Churches with the Orthodox Church collaborating with the state to bring about repression by using the law against proselytizing as a weapon to restrict any type of public or private witness.

The following is a chronology of the events and

\footnotetext{
${ }^{1}$ Ibid.

${ }^{2}$ Ibid.

${ }^{3}$ Lohne, 12 .
} 
developments within the Seventh-day Adventist Church in Russia from 1886 to 1914.

July 1886: First Russian church organized by Conradi.'

September 1886: Second small church organized in

Alexandrofke. ${ }^{2}$

1890: SDA membership was $356 .^{3}$

1891: Russian SDA Church organized and church officers selected. ${ }^{4}$

1895: SDA membership was $660 .{ }^{5}$

1897: A committee between september 20-25. There were 22 churches and 886 members, of which 100 were Russians and the rest $\operatorname{German} .^{6}$

July 1886: First Russian church organized by Conradi. ${ }^{7}$

September 1886: Second small church organized in

Alexandrofke. ${ }^{8}$

1890: SDA membership was $356 .{ }^{9}$

${ }^{1}$ Institut Perevoda Biblii, 10.

${ }^{2}$ Ibid., 11.

${ }^{3}$ Ibid.

${ }^{4}$ Ibid., 12.

${ }^{5}$ Ibid.

${ }^{6}$ Ibid .

${ }^{7}$ Institut Perevoda Biblii, 10.

${ }^{8}$ Ibid., 11.

${ }^{9}$ Ibid. 
1891: Russian SDA Church organized and church officers selected. ${ }^{1}$

1895: SDA membership was $660 .^{2}$

1897: A committee between september 20-25. There were 22 churches and 886 members, of which 100 were Russians and the rest German..$^{3}$

1905: Nicholai II published new rules on religious liberty and in July 1905 the first Eastern Russian Conference was organized. It consisted of three missionary fields: Southern, Northern, and Middle. Church statistics showed 2,103 members, and 31 pastors.

1907: Sweden decided to join the Russian SDA organization. ${ }^{5}$

1914: Because of World war I all churches were closed except those in Moscow, Kiev, and Riga which remained opened. This ruling was due to German church members suspected of spying. ${ }^{6}$

Evangelism, 1917-1985

The Seventh-day Adventist Church suffered greatly from the repression of religion which was unleashed after the 1917

\footnotetext{
${ }^{1}$ Ibid., 12 .

${ }^{2}$ Ibid.

${ }^{3}$ Ibid.

${ }^{4}$ Ibid., $13-14$

${ }^{5}$ Ibid., 14.

${ }^{6}$ Ibid., 16.
} 
Revolution. Communism was determined to wipe out all traces of religion, defined by Marxist doctrine as "the opium of the people." As pointed out by Roland R. Hegstad, "of 3000 Seventhday Adventists sent to prison camps, only 500 returned. of 179 Adventist pastors exiled to Siberia, only four returned." ${ }^{1}$ Under such repression public evangelism was not possible. All evangelism had to be underground activity from person to person. Personal evangelism was carried out through various opportunities.

1. Sabbath School Groups: Small Sabbath School groups organized and once every week met to discuss the Bible. In these meetings, friends and neighbors were invited and thus the church membership grew.

2. Home Funeral Evangelism: Orthodox Priests had been granted permission to preach to groups of people gathered at the home of a deceased person. Such permission was granted after the Second World war in 1945. SDA evangelists took advantage of this provision and fully utilized it. Large gatherings of people were invited to the home of those who had died and for three days full-fledged "public evangelism" took place, in which sermons were preached and invitations given to accept Christ.

3. Graveyard Evangelism: The graveyard gathering was used as another opportunity for evangelism, as preaching at such

\footnotetext{
${ }^{1}$ Roland R. Hegstad, "Challenge At," Liberty, March/April $1991,11$.
} 
gatherings was allowed. The graveyard service was purposefully extended to take enough time so that this evangelism opportunity could be fully utilized.

4. Memorial Ceremony: Forty days after a person died the Orthodox Church conducted a special ceremony in which relatives and friends were invited to share food and listen to a preaching service. Such special ceremonies were also organized by SDA Church members with friends, relatives, and neighbors of the deceased invited to a gospel feast in which public evangelism took place.

5. Biological Growth: SDA members' children where converted and joined the church.

According to Alf Lohne the church did not only survive but experienced a steady growth as reflected by the figures in table 3, which show growth in church membership from 1910 to 1985.

The chronology of events listed below cover the years 19221960 .

1922: The church published two journals and the Sabbath School Quarterly in Russian. ${ }^{1}$ The President of the Russian organization was G. Lepsak.

1923: SDA statistics: 6 Union Conferences; 9,034 members; 381 churches.

\footnotetext{
${ }^{1}$ Ibid., 18 .
} 
TABLE 3

CHURCH MEMBERSHIP IN RUSSIA IN THE 1910-1985 PERIOD

\begin{tabular}{cc}
\hline Year & Members \\
1910 & 3,952 \\
1915 & 5,236 \\
1920 & 8,200 \\
1925 & 12,434 \\
1930 & 13,709 \\
1935 & No report \\
1940 & 16,513 \\
1945 & No report \\
1950 & 21,611 \\
$1951-1981$ & No report (30 years) \\
1982 & 30,604 \\
1983 & regl, 305 \\
\hline Source: Roland & Hegstad, "Challenge A+," Liberty, March/April,
\end{tabular}
1991, 11.

1924: SDA church statistics: 11,500 members and 430

churches. ${ }^{1}$

1928: Religion in Russia entered its dark period because of restrictions in religious liberty which required "all religions to be registered" and allowed the "city committee as the only trustee. $"{ }^{2}$

1931: The Russian Union Conference Committee met with 29

${ }^{1}$ Year Book of Seventh-day Adventist Denomination (Washington, DC: Review and Herald Publishing Association, 1924), 105-111.

${ }^{2}$ Institut Perevoda Biblii, 19 
pastors and decided to make every church independent. ${ }^{1}$

1933-1946: Pastor Gregoriev was president of the Russian organization; he was also one of the 178 exiled in Siberia. ${ }^{2}$

1944: The government started registering SDA churches again. ${ }^{3}$

1946: SDA statistics: 13,300 members and 300 churches. ${ }^{4}$

1960: The Council of Religious Affairs again closed Russian religious organizations. ${ }^{5}$

Alf Lohne's description of his visit to a Russian SDA Church in 1969 gives some clues to the difficult situation faced following Nikita Khruschev's anti-religious campaign of 1959-1964.

On the 1969 visit, no church dared to invite us to preach when we attended Sabbath services or midweek prayer meetings. In the Moscow church one Sabbath we wrote a greeting on a piece of paper and the local pastor read it to the congregation. In another we received permission to give greetings from the pulpit. ${ }^{6}$

The opening of communication between the General Con-ference and the Russian SDA Church ca. 1970 helped create an urgent sense of mission among SDA Church members in Russia.

In 1970 M. P. Kulakov was appointed by the SDA Church in

${ }^{1}$ Ibid., 19-20.

${ }^{2}$ Ibid., 21 .

${ }^{3}$ Ibid.

${ }^{4}$ Ibid.

${ }^{5}$ Ibid. , 24

${ }^{6}$ Lohne, 20 . 
Russia as representative to the General Conference (GC), headquarters in Washington, DC. ${ }^{1}$ Four years later (1974) Theodore Carcich, Vice President of the GC visited Moscow. ${ }^{2}$ These developments regarding communication between the GC and the SDA Church in Russia, and particularly the visit of the GC Vice President, resulted in Russia's sending delegates to the GC session in 1975. For the first time in fifty-seven years delegates from the Soviet Union were present: Michael Kulakov, A. Parasei, Yuri Tomenko, and others. ${ }^{3}$

As a result of the improving relations, the 1980 General Conference in Dallas was attended by nine delegates who represented the SDA Church in Russia." Such visits exposed the Russian Church to global trends in evangelism and prepared the church leaders in Russia to accept new strategies such as public evangelism. Excitement over the developments in Russia was also evidenced at the Annual Council of the GC in 1981, at which the introduction of four special Russian guests was described as a "moment of high drama." During their introduction the assembly

${ }^{1}$ Ibid., 25-26.

${ }^{2}$ Ibid. , 26 .

${ }^{3}$ R. R. Hegstad, "The Day in Vienna," Review and Herald, July. $13,1975,2$.

${ }^{4} J o c e l y n$ Fay, "Preparation for the Session," Adventist Review, April 17, 1980, 3 .

${ }^{5}$ William G. Johnsson, "Mission, Keynotes Annual Council," Adventist Review, November 12, 1981, 4. 
"applauded spontaneously" as an expression of relief at what was happening to the SDA Church in Russia. In the same year the SDA Church in Russia officially organized into five conferences:

Central, North Caucasus, Volga Ural, Western Siberia, and Far East. ${ }^{1}$ The organization into conferences was also the beginning point to support public evangelism in Russia because, unlike personal evangelism, public evangelism requires an organizational structure for support if it is to be formally implemented.

Relations between church and state kept on improving, and the SDA Church benefited greatly. By 1985 there were more than 32,000 Adventists in USSR. ${ }^{2}$ James Fly shares the reaction of the worldwide SDA Church at the GC Session in New Orleans in 1985.

I feel a chill shiver up and down my spine as the Russian delegation of seven headed by M. P. Kulakov marches on stage. The audience breaks out into spontaneous applause. . . This is the third General Conference session Russian Adventists have attended but the first one at which they have presented an evening report. ${ }^{3}$

Alf Lohne was privileged to witness the growth of the SDA Church in Russia during his many visits. In his 1969 visit Lohne was not even allowed to greet church members, but in 1985 he gave an Easter Sermon not only to the SDA Church in Moscow and Oriol,

\footnotetext{
${ }^{1}$ Institut Perevoda Biblii, 30 .

2James L. Fly, "The Day in Review," Adventist Review, July $5,1985,2$.

${ }^{3}$ Ibid. , 2-3.
} 
but to other non-SDA Churches as well. ${ }^{1}$ Lohne also preached freely to other Adventist Churches during his 1985 visit. ${ }^{2}$ Such an atmosphere rendered great opportunities for public evangelism as evangelists were now free to preach to the masses. It was now possible to invite the general public to churches and to reach them through public campaigns.

As described above, within the period 1917 to 1985 the SDA Church in Russia moved from persecution to freedom. Even when persecution was at its height, the church never lost sight of its mission. It remained faithful to mission even though public evangelism was not used. However, by 1985 the opportunity was ripe for the SDA church to consider adopting public evangelism as a mission strategy.

\section{Evangelism, 1985 to Present}

A national disaster provided opportunities for GC leaders to communicate with Russian officials. In the wake of the nuclear disaster at Chernobyl in 1986, the General Conference scored a major breakthrough in the USSR, as noted by GC president, Neal C. Wilson:

For the first time in the church's history we are able to share with the highest levels of Soviet leadership who

${ }^{1}$ Lohne, Adventists in Russia, 9 .

${ }^{2}$ Alf Lohne, "Siberian Believers Flock to Spiritual Meeting," Adventist Review, September 26, 1985, 20-22. 
Adventists are, what we believe, and the extent of the church's world wide activity. ${ }^{1}$

The Chernobyl nuclear disaster occurred only two weeks before the trip to Russia by Adventist church leaders who, despite the nuclear danger, did not cancel their trip. This bold decision won the favor of USSR officials because many other groups canceled their visits, including delegates to a round-table conference hosted by the Moscow patriarchate of the Orthodox Church. Bert B. Beach, GC Public Affairs and Religious Liberty director, who was on the GC team, received a sudden invitation from the Orthodox Church to replace the American delegation that had canceled its trip in the aftermath of the disaster. ${ }^{2}$ The Soviet leadership had enough time to listen to the Adventist leaders who had risked their lives to meet their commitments in Russia. This visit impacted favorably on government officials and, as a result of the improved relations, helped pave the way for public evangelism by visiting American evangelists.

GC President, Neal C. Wilson, used this opportunity to present specific requests to the officials on behalf of the SDA Church in Russia. The requests put forward cleared the way for massive evangelistic crusades in Russia as they allowed for national recognition of the SDA Church, literature distribution,

${ }^{1}$ Carlos Medley, "Breakthrough in the USSR," Adventist Review, August 7, 1986, 6 .

${ }^{2}$ Ibid., 6-7. 
and the training of evangelists. Wilson requested:

1. Recognition of the SDA Church nationally so that an Adventist committee would be authorized to deal with the whole Soviet Union

2. Equal treatment without discrimination to be given to the Adventist Church as was given to other denominations, such as Baptists and the orthodox Church, so that the Church could have a headquarters in Moscow

3. Printing and distribution of SDA literature

4. Establishment of a seminary training program for Adventist ministers. ${ }^{1}$

Wilson and Beach noted ten points that impressed them most:

1. Russians were deeply religious and less materialistic thạn Westerners.

2. Music played a central role in Christian life.

3. Peace was the theme of all people.

4. There was deep respect for church leadership at the GC.

5. A major emphasis on altruism and group solidarity was evident.

6. The church had a sense of identity with the world church without a spirit of ecclesiastical isolationism.

7. There was a spirit of cooperation and unity among pastors.

8. Adaptability was obvious.

9. The church was loyal to fundamental Adventist doctrines.

\footnotetext{
${ }^{1}$ Ibid. , 7.
} 
10. Gradual trends toward a more open society were evident. ${ }^{1}$ These characteristics would create an environment conducive to a public evangelistic emphasis in Russia. In 1986 the church organized and held its first Union Session. Eighty-five delegates from 115 churches, representing 6,406 members, attended. The main climax of this meeting was that the Church Manual was accepted for the first time and the nominating committee elected M. K. Kulakov as president. ${ }^{2}$ This organization helped to focus on the church's missions and to coordinate public evangelism.

\section{Zaokski Theological Seminary}

In order to meet the demand for church evangelists and workers, a seminary had to be established in Russia. The existence of a seminary would have great impact on training for public evangelism. After negotiations "the Soviet Government granted permission for the church to establish a training center for Adventist ministers." ${ }^{3}$ on December 2, 1988, Neal C. Wilson, the GC President, together with Konstantine Kharchev, Chairman of the Council of Religious Affairs of the Soviet Union, officially opened the center. More than 500 pastors already in service were expected to undergo theological training at this seminary, and training in public evangelism would also be given.

\footnotetext{
${ }^{1}$ Ibid.

${ }^{2}$ Institut Perevoda Biblii, 32 .

${ }^{3}$ Rose Otis, "Adventist Church Dedicates First Seminary in USSR," Adventist Review, February 16, 1989, 6 .
} 
The establishment of the SDA Theological Seminary at Zaokski was another milestone in Kussian Adventism with great implications for public evangelism. Not only was this the first Adventist Theological seminary in Russia, it also was the "first Protestant Institution of higher theological education in the USSR." 1 The contribution of the seminary to evangelism was evident when the witnessing of students led to the "six satellite churches" in and around Zaosksi by $1992 .^{2}$ Thousands of visitors from all walks of life, including "teachers, engineers, scientists, and medical doctors," visited the seminary and attended lectures and sermons. ${ }^{3}$

Soviet Officials Visit the General Conference

A long-term, systematically planned public relations program by the General Conference paid dividends. Soviet officials and outstanding Russian physicians had the opportunity to visit Adventist institutions in the United States, including hospitals and publishing houses. They were impressed by the Adventist work and the facilities. ${ }^{4}$ Such impressions would boost the image of

${ }^{1}$ M. P. Kulakov, "Bright Prospects in the U.S.S.R.," Adventist Review, July 12, 1990, 23.

${ }^{2}$ Mikhail Kulakov, God's Soviet Miracles (Boise, ID: Pacific Press Publishing Association, 1993), 12.

${ }^{3}$ Ibid. , 23.

${ }^{4}$ Ibid., 7 . 
the SDA Church in Russia and help create new opportunities for public evangelism.

The GC had a long-standing program to build rapport with Soviet leaders. In 1986 the General Conference, under the leadership of Neal C. Wilson, went an extra mile to strengthen relations with the USSR by hosting Konstantine Kharchev, Chairman of the Council for Religious Affairs, on a tour of Adventist institutions in the United States of America. ${ }^{1}$ The importance of the tour to the SDA Church in Russia was summarized by Neal C. Wilson: "You cannot overestimate the importance of a visit like this. . . I am very optimistic about the outcome of the visit." ${ }^{2}$

Kharchev's visit to the SDA Church headquarters sent positive signals on the official acceptance of the SDA Church in Russia. Kharchev himself summarized the purpose of his visit to the USA and referred to the earlier visit to Russia by Neal C. Wilson. Kharchev's response was:

We are very glad with the outcome of his [Wilson's] visit. We believe that the co-operation between our organizations will undoubtedly strengthen. The sole purpose of my visit is to learn more about religious organizations and their leaders, and to create more favorable conditions for strengthening ties with religious organizations in our countries. ${ }^{3}$

The evangelistic thrust of the SDA Church in Russia greatly

${ }^{1}$ Carlos Medley, "Soviet Leader Visits GC," Adventist Review, November $13,1986,6$.

${ }^{2}$ Ibid.

${ }^{3}$ Ibid. 
benefitted from the change in official attitude toward the church during the celebration in 1988 of one thousand years of Christianity in Russia. ${ }^{1}$ A dramatic turnaround in the official Soviet attitude toward religion was made possible by Gorbachev, who suddenly turned away from the long-cherished Communist view that religion is "false from start to finish." ${ }^{2}$ An editorial in Pravda, September 28, 1986, not only summarized the experiences of religious groups in general, but also reflected what was going on within the SDA Church.

It is known that, with the building of socialism in the USSR, there was a mass departure of the working people from religion. The scientific world view prevails in our society. This has given rise among some Soviet citizens, and even among certain ideological cadres, to a conciliatory attitude toward religion, to the notion that it will wither away of its own accord. On the contrary, religious organizations, adapting to the changing situation in the country and updating church dogmas, are seeking not only to retain their influence over believers but also to draw new people, especially young people, into their ranks. ${ }^{3}$

"Drawing new people into their ranks" referred to evangelism and that is exactly what Adventists were concerned about. Public evangelism was going to drastically change the face of the Russian church.

Neal C. Wilson, GC President, described the events in the

\footnotetext{
${ }^{1}$ Ehlers et al., 123.

${ }^{3}$ Ibid.

${ }^{3}$ Ibid.
} 
Russian SDA Church as "almost miraculous." after the 1986 visit to the Soviet Union by GC leaders and their subsequent meeting with Soviet officials at the highest levels, the General Conference Executive Committee voted to approve the request of the Seventh-day Adventist Church in Russia to be organized into a division of the General Conference. This was the climax of many years of hard labor. The Adventist Review reported:

For many years the church has been pressing the soviet government for full recognition of the SDA Church authorized to operate throughout the USSR. The Soviet Union is now ready to grant this request. The projected date for initiating such an organization is August 8-13, $1989 .^{2}$

Two hundred and fifty delegates, including one hundred lay persons, were authorized by the Soviet Union Government to attend this organizational council. This was a major turning point in the history of the SDA Church in Russia. Such organization was necessary for empowering the church in Russia to turn to evangelism as its main business.

M. P. Kulakov summarized the rapid progress of the SDA Church in Russia in his report on the USSR Division presented to the General Conference session on July 10, 1990.3 Kulakov

${ }^{1}$ William G. Johnsson, Carlos Medley, and Myron $\mathrm{K}$. Widmer, "Spring Meeting Approves New Division, Higher Wages," Adventist Review, April 20, 1989, 6 .

${ }^{2}$ Ibid.

${ }^{3}$ Kulakov, "Bright Prospects in the U.S.S.R.," 22. 
identified glasnost and perestroika as having tremendous impact on the religious sphere and concluded that "many doors that had been closed for believers for a long time have opened." In the area of publishing, all printing houses still belonged to the state as the new law on the freedom of the press was yet to be passed. ${ }^{2}$ However, on the question of church property, the SDA Church had gained from the new policy changes. Kulakov reported restoration of church property:

During the past two years the government not only abandoned all limitations on the construction of new church buildings, but has been returning those buildings that were taken away in the past. In many cities local authorities are helping our pastors to rent music halls and theaters to conduct charity concerts of Christian music. ${ }^{3}$

\section{Innovations in Evangelism}

The rapid changes that have occurred in Russia have thrown all doors wide open for the church to try out new ideas in the area of evangelism. Some of the innovations are listed below.

Mass media evangelism

Mass media evangelism has played a major role in Russia since the political changes in Russia engineered by Gorbachev.
${ }^{1}$ Ibid.
${ }^{2}$ Ibid
${ }^{3}$ Ibid. 
Daniel $R$. Guild reported on the work of Adventist broadcasting in Russia being carried out by the Voice of Hope Media Center located in Tula. With Peter Kulakov as its director and speaker, the three angels' message was preached to every part of Russia.' Many new opportunities exist now because of print and television media. Television evangelism has helped to create public interest in learning more about Adventists and their life-style because SDA programs and interviews are beamed on public and private channels to millions of viewers and listeners across Russia. ${ }^{2}$ Opportunities for evangelism created by mass media included publicity of the agriculture program at the SDA Seminary, which in 1991 led to over 2,500 people visiting the Seminary every month to see for themselves and learn more about Adventists. ${ }^{3}$

The Voice of Hope Media Center produces the most popular religious radio programs in Russia and also co-ordinates television broadcasts in Russian of It Is Written. ${ }^{4}$ Media impact on evangelism is evidenced by the fact that, by $1995,60,000$ people had enrolled in the Bible Correspondence School which is

${ }^{1}$ Daniel R. Guild, "Adventist Radio Blankets Former Soviet Union," Adventist Review, December 31, 1992, 21-22.

${ }^{2}$ J. R. Spangler, "The Soviet Union: A Decade of Destiny," Adventist Review, February 7, 1991, 9.

${ }^{3}$ Ibid. , 10

${ }^{4}$ Ted N. C. Wilson, "God's Miraculous Power in the Euro-Asia Division," Adventist Review, July 7, 1995, 7. 
attached to the Mass Media Center. ${ }^{1}$

School evangelism

One of the major evangelistic modes which has been used in Russia recently is the church school. In 1990 there were no SDA church schools in Russia, but by 1995 there were four schools with a combined enrollment of 313 students. These were located in Tula, Zaokski, Ryazani, and Moscow. ${ }^{2}$ Recently a unique public-school evangelism project was started. This project involves contacting local public schools and arranging for Adventist volunteers and paid teachers to provide religious and moral education at convenient times. ${ }^{3}$ The students who are reached through this project "are invited to the homes of Seventh-day Adventists or to church programs." 4

Service evangelism

The work of the Adventist Development and Relief Agency (ADRA) started in Russia only in 1990, and has expanded. ${ }^{5}$ The relief services provided by ADRA have received favorable recognition in both public and government circles. ${ }^{6}$ This service

${ }^{1}$ Ibid.

${ }^{2}$ Ibid . , 8 .

${ }^{3}$ Ibid.

${ }^{4}$ Ibid.

${ }^{5}$ Ibid. , 6 .

${ }^{6}$ Ibid. 
involves helping people and communities in crisis situations. E.

G. White supports service evangelism when she says:

Many can be reached only through acts of disinterested kindness. Their physical wants must first be relieved. As they see evidence of our unselfish love, it will be easier for them to believe in the love of Christ. ${ }^{1}$

Health evangelism

About 1993, the Seventh-day Adventist Church in Russia established its first clinic. Its three objectives were medical rehabilitation, dental care, and lifestyle change. ${ }^{2}$ Wilson pointed out that at this outstanding health center, "witnessing activities" were "prominent in the centers' overall program." 3

Music evangelism

The 1985-1990 period challenged the Russian SDA Church to devise new ways of evangelism. Great opportunities, never dreamed of, lay before the church after the fall of Communism. Charity concerts were a mode of public evangelism, marking the beginning of a new era of public meetings.

In such concerts, various choirs and evangelists collaborated. The choir concerts were advertised and tickets sold. A thirty-minute choir presentation was followed by a

${ }^{1}$ E. G. White, Testimonies for the Church, 9 vols. (Washington, DC: Review and Herald Publishing Association, 1948), $9: 111$.

${ }^{2}$ William G. Johnsson, "The Risen Christ over Red Square," Adventist Review, June 18, 1992, 15.

${ }^{3}$ Wilson, "God's Miraculous Power," 7. 
sermon and by more singing and an appeal. Many people responded to these meetings conducted for a few days in one place.

\section{Public Evangelism Explosion}

The single most effective tool which has resulted in quantum growth within the Russian SDA Church has been public evangelism. To accommodate this growth, the church built 236 new constructions from 1985 to 1990. Membership increased to 34,146 by 1990, and 3,179 members were baptized within one year. ${ }^{1}$ Baptisms recorded in 1990 were a result of many evangelistic crusades conducted in many cities by Russian and American evangelists, as well as speakers of other nationalities. ${ }^{2}$ This evangelistic drive was made possible by the fall of Communism, of which J. R. Spangler observed: "The climate of political and religious freedom now is not only dramatic but intensely emotional, when compared with only a few years ago." ${ }^{3}$

Spangler was appointed as evangelism consultant for the USSR. The first plan adopted by the division was to promote short evangelistic crusades "in every city and town, especially where there are church members." ${ }^{4}$ For the purpose of coordinating these evangelistic crusades a special operation known as the Euro-Asia

\footnotetext{
${ }^{1}$ Kulakov, "Bright Prospects in U.S.S.R.," 24.

${ }^{2}$ Insitut Perevoda Biblii, 8.

${ }^{3}$ Spangler, 8 .

${ }^{4}$ Ibid., 10 .
} 
Affairs Office was organized at the General Conference headquarters to nurture the fledgling division, and to "help with evangelism, church construction, and other special projects."1

Foreign evangelists in Russia

Largely because of the leadership and vision of J.R. Spangler, the former USSR embarked on this new path. Public evangelism in the Euro-Asia Division accounted for 12,000 new believers baptized in 1991 alone.

Spangler wrote:

During 1991 our plan called for 11 field schools of evangelism in what was then the Soviet Division, with classes for the pastors each morning and evangelistic meetings for the public each evening. On weekends classes in soul winning were taught to the lay members. ${ }^{2}$

Public evangelistic crusades were made possible through implementation of a project named "Evangelism Advance," which involved bringing expatriate evangelists to the Euro-Asia Division. ${ }^{3}$ Calvin Rock summarized the impact that these crusades were having on church growth in the Euro-Asia Division, of which Russia is a part, by pointing out that the membership had grown Erom 35,000 in 1990 to 70,000 by $1993 .^{4}$ A total of fourteen

${ }^{1}$ Wilson, "God's Miraculous Power," 5.

${ }^{2} J$. R. Spangler, "Thousands Turn from Communism to Christ," Adventist Review, June 4, 1992, 27.

${ }^{3}$ Wilson, "God's Miraculous Power," 5.

${ }^{4}$ Calvin Rock, "Meetings Reap Rearly 1000," Adventist Review, January 28, 1993, 22 . 
evangelistic campaigns was con-ducted in 1991 and these increased to seventy-one crusades in $1992 .^{1}$

David Newman pointed out that, in 1992 alone, SDA pastors of the Euro-Asia Division planned 187 evangelistic crusades, and 60 campaigns, were conducted by evangelists from Germany, Australia, England, and the United States. ${ }^{2}$ During 1993 more than 250 evangelistic crusades were conducted by the SDA Church in Russia. ${ }^{3}$

A few of the documented public evangelistic crusades conducted in Russia between 1990-1995 have demonstrated a massive response of the Russian people toward the gospel invitation. Spangler, evangelism consultant to the Euro-Asia Division, conducted several crusades in Russia. During his first evangelistic crusade, sponsored by the Moscow Church in October 1990, he made an altar call "and the aisles were jammed with people who came forward for prayer and counseling."4. Spangler also confessed that "this was the first evangelistic meeting I ever conducted where people bought tickets." ${ }^{5}$ The people's hunger for the word of God was further reflected by those "who

${ }^{1}$ Ibid.

2Spangler, "Thousands Turn from Communism," 27.

${ }^{3}$ David Newman and Sharon Cress, "Super Evangelism in Moscow," Ministry, November 1993, 15.

${ }^{4}$ Spangler, "Thousands Turn from Communism," 9. ${ }^{5}$ Ibid 
almost fought over who would get a Bible" being sold. ${ }^{1}$ Public evangelistic crusades in Russia had many surprises for evangelists and church leaders.

Some of the public evangelistic crusades resulted in the development of a long-term plan for a given locality. Such was the case with Bruce Johnston's crusade in St. Petersburg in 1991. This four-week crusade ended with 3.23 new members baptized, and thirty-five Russian pastors completing a field school of evangelism. ${ }^{2}$ Besides the baptisms, 2,500 finished a twenty-fourlesson Bible study course, and 80,000 Bibles plus 6,000 copies of Christ our Savior were distributed. In. 1992 a five-year plan to conduct two major crusades each year was drafted, with the objective of planting ten to fifteen new churches in St. Petersburg. ${ }^{3}$

In 1992, Mark Finley conducted an evangelistic crusade in Moscow in the Kremlin Congressional Hall; the meetings were attended by 10,000 people a day. This crusade created a national stir among political and religious circles and was published and debated in newspapers, on radio, and television throughout the former USSR. ${ }^{4}$ In order to meet the public demand for the gospel

${ }^{1}$ Ibid.

${ }^{2}$ Daniel R. Guild, "Meetings Triple Membership in st. Petersburg," Adventist Review, March 19, 1992, 19-20.

${ }^{3}$ Ibid.

${ }^{4}$ Spangler, "Thousands Turn from Communism," 27-28. 
in Moscow, Mark Finley conducted another mega-public crusade in 1993 and hired the Olympic Stadium for five weeks. An average of 16,000 people attended the meetings daily. ${ }^{1}$ of the 325 full-time volunteers for this crusade, 165 were Americans and 160 were Russians. Within five weeks of the end of this crusade, SDA Churches in Moscow increased from four to twelve, and twelve new pastors were appointed. This crusade was a great boost to public evangelism as local Russian pastors received training in public evangelism. The climax of the crusade was the baptism of 1,600 new church members. ${ }^{2}$

Some of the public evangelistic crusades resulted in the newly established Russian churches being adopted as "sister churches" by local churches in the United States. Such was the case with Duane McKey's crusades in St. Petersburg and Magadan. The crusades resulted in 405 baptisms in St. Petersburg ${ }^{3}$ and 278 in Magadan. ${ }^{4}$

Explosion is perhaps the best way to describe the impact of public evangelism in Russia. Calvin B. Rock conducted a crusade in Novosibirsk, Siberia, in 1992, and 947 new members were baptized into the church within a matter of weeks. ${ }^{5}$ Konrad

${ }^{1}$ Newman and Cress, 15.

${ }^{2}$ Ibid. , 15-19.

${ }^{3}$ Janet Kangas, "Mission Outreach Spurs Local Church Growth," Adventist Review, November 12, 1992, 21.

${ }^{4} \mathrm{Cindy}$ Chamberlin, "Operation Bearhug Reaches across Pacific," Adventist Review, November 19, 199.2, 20.

${ }^{5}$ Rock， 22 . 
Mueller, a retired minister, conducted a public crusade in Astrakhan and more than 120 new members were baptized and a new church was built. ${ }^{1}$ Gary Kent, an Australian evangelist, conducted a public evangelistic crusade in Omsky, and 800 people were baptized. ${ }^{2}$ Lonnie Melanshenko conducted a crusade in Permy and 469 people were baptized. ${ }^{3}$ Many other crusades were also conducted by international evangelists in $1993 .{ }^{4}$

\section{Russian evangelists}

Russian pastors also conducted evangelistic crusades in Russia. Michael Zozulin conducted meetings in Amursk; these resulted in an increase of membership from six to fifty-nine. The local government gave the group a church building and furniture in appreciation for the community service. ${ }^{5}$

Hundreds of other evangelistic crusades have been conducted each year by Russian pastors. A. Antonyk organized an evangelistic crusade in the Nizhniy Novgorod Region (1994) in the town of Reshitikha and organized a church there. V. Stolear also conducted an evangelistic crusade in the Nizhniy Novgorod (1995)

${ }^{1}$ Konrad Mueller, "Redeeming the Past," Adventist Review, March 30, 1995, 18-19.

${ }^{2}$ Institut Perevoda Biblii, 42 .

${ }^{3}$ Charles R. Taylor, "Making Up for Lost Time," Adventist Review, December 22, 1994, 19-20.

${ }^{4}$ Ibid.

${ }^{5}$ Ibid. , 18 . 
district and established the Kstova Church. I conducted six crusades, two in the Far East Conference (1993) and four in the Volga Vatsky Conference (1995).

In 1996, Vadim Butov conducted an effort in the Kirov region, in which more than 200 people were baptized and two new churches were established. One of the unique features of this effort was that Bibles were not given away, but were. sold. However, people were all too happy to buy these Bibles. Other literature was freely distributed.

Women have played a role in evangelizing Russia. Natasha Ivanova reports on three laywomen whose dedication resulted in growth of the sixteen-member Adventist group in Novomoskovsk to sixty-five members within four years. ${ }^{1}$

\section{Public Evangelism and Church Growth}

The warning given by Patrick Johnstone in 1993 concerns Adventist evangelism also.

Mass evangelism . . . has created enormous interest and high publicity, but mass response to appeals has yielded relatively few disciples and new church members. Glowing reports in the West of conversions are premature! There are simply not the resources in counselors, disciplers, follow up materials, or congregations able to lead these enquiries from total ignorance of the gospel to a living life-changing faith. ${ }^{2}$

Church growth in Russia has necessitated changes in the

${ }^{1}$ Natasha Ivanova, "Four Years without Holidays," Adventist Review, Special Issue, June 1995, 20.

'Johnstone, 468 . 
organizational structure. Ted N. C. Wilson wrote of the division of two Unions.

In mid-1994, at its own session the Russian Union Conference was divided into two new Unions, the East Russian Union Mission and the West Russian Union Conference. ${ }^{1}$

In tables 4 and 5 the statistical profiles of the two Unions are presented.

\section{TABLE 4}

CHURCH MEMBERSHIP, EAST RUSSIAN UNION MISSION, 1994

\begin{tabular}{lc}
\hline Conference & No. of Members \\
\hline Far East Conference & 2,276 \\
Eastern Siberian Mission & 1,487 \\
Western Siberian Conference & 3,121 \\
Total & 6,884 \\
Total number of churches & 78 \\
\hline
\end{tabular}

Source: Institut Perevoda Biblii, s Dobroi Vestiu k Svoim Sootechestvennikam (With good news to our compatriots). (Zaokskii: Institute Perevoda Biblii, 1996), 41.

Volga Vatsky is one of the conferences of the Western

Russian Union. Table 6 shows the remarkable growth in number of churches, from twelve in 1994 to forty-four in 1996.

As far as church membership is concerned, the Volga Vatsky Conference has also recorded a high rate of growth, as reflected in table 7 .

At the beginning of 1994 there were 3,999 SDA members in the

${ }^{1}$ Wilson, "God's Miraculous Power," 6. 
Volga Vatsky Conference and these increased to 5,909 members by 1996. The conference has also reported membership 1oss. The highest loss was recorded in 1994 when 2,477 members were struck

TABLE 5

CHURCH MEMBERSHIP, WEST RUSSIAN UNION CONFERENCE, 1994

\begin{tabular}{|c|c|c|c|}
\hline \multicolumn{3}{|l|}{ Conference } & No. of Members \\
\hline \multicolumn{3}{|l|}{ Volzskaya } & 3,470 \\
\hline \multicolumn{3}{|c|}{ Volga-Vyatsky } & 3,999 \\
\hline \multicolumn{3}{|c|}{ North Western } & 3,127 \\
\hline \multicolumn{3}{|c|}{ North Caucasus } & 6.374 \\
\hline \multicolumn{3}{|l|}{ Ural } & 3,479 \\
\hline \multicolumn{3}{|l|}{ Central } & 5,685 \\
\hline \multicolumn{3}{|l|}{ Southern } & 3,909 \\
\hline \multicolumn{3}{|l|}{ Total } & 30,043 \\
\hline \multicolumn{3}{|c|}{ Total number of churches } & 164 \\
\hline \multicolumn{4}{|c|}{$\begin{array}{l}\text { Source: "Western Russian Union Statistical Report, } 19 \\
\text { Klimovsk, Moscow Region, Russian Federation. }\end{array}$} \\
\hline \multicolumn{4}{|c|}{ TABLE 6} \\
\hline \multicolumn{4}{|c|}{ NUMBER OF CHURCHES, VOLGA VATSKY CONFERENCE, 1994-1996 } \\
\hline \multicolumn{3}{|c|}{ Year } & No. of Churches \\
\hline \multicolumn{3}{|c|}{1994} & 12 \\
\hline \multicolumn{3}{|c|}{1995} & 37 \\
\hline \multicolumn{3}{|c|}{1996} & 44 \\
\hline \multicolumn{3}{|c|}{ Total } & 44 \\
\hline
\end{tabular}


from the church records. The possible explanation for such a big loss can be traced to the Carter Crusade held in 1992, two years earlier. Volga Vatsky Conference has a rule not to drop missing members for at least two years. The bulk of the recorded members had joined the church due to the Carter Crusade, but more than 60 percent of them were missing after two years.

TABLE 7

MEMBERSHIP GROWTH, GAIN, AND LOSS, VOLGA VATSKY CONFERENCE, 1994-1996

\begin{tabular}{cccccc}
\hline Year & $\begin{array}{c}\text { Membership } \\
\text { beginning } \\
\text { of year }\end{array}$ & Gain & Loss & $\begin{array}{c}\text { Membership } \\
\text { end of year }\end{array}$ & $\begin{array}{c}\text { Growth } \\
\text { Percentage }\end{array}$ \\
\hline 1994 & 3,999 & 2,566 & 2,477 & 4,088 & 2.2 \\
1995 & 4,088 & 1,111 & 246 & 4,953 & 21.2 \\
1996 & 4,953 & 1,393 & 437 & 5,909 & 19.3 \\
Total & 5,909 & 5,070 & 3,160 & & 47.7 \\
\hline
\end{tabular}

Source: Conference Session report, January 9-11, 1997, Volga Vatsky Conference.

A close analysis of the membership loss in Volga Vatsky Conference is presented in table 8 . The total membership loss in Volga Vatsky Conference for the period 1994 to 1996 was 3,160. The breakdown of the loss shows that 11 percent were transferred, while 23 percent died. The highest loss was due to disfellowshiping, which accounted for 66 percent of the loss.

Other highlights of the Volga Vatsky Conference report are the details concerning the crusades conducted from 1994 to 1996 . A 
total of thirty-nine crusades were conducted. Of these sixteen were conducted by foreign evangelists, six by local pastors, six by local full-time evangelists, eight by students, and three by laypersons.

TABLE 8

SOURCES OF LOSSES, VOLGA VATSKY CONFERENCE, 1994-1996

\begin{tabular}{lcc}
\hline \hline Source of Loss & Total & Percentage \\
\hline By letter & 333 & 11 \\
By death & 724 & 23 \\
By excommunication & 2,103 & 66 \\
Total & 3,160 & 100 \\
\hline Source: Conference Session & report, January $9-11$, & 1997, \\
Volga Vatsky Conference. &
\end{tabular}

During the same period one church was opened in the Volga Vatsky Conference every thirty-three days. One person was baptized every 5.5 hours.

Ted N. C. Wilson rightly noted that "the full story of the unfolding of God's providence in Euro-Asia Division would fill many books." 1

A comprehensive analysis of the source of backsliders is presented in chapter 3 . The greatest source of backsliding is disfellowshiping. This fact should be a cause of great concern to these involved in public evangelism.

${ }^{1}$ Wilson, "God's miraculous Power," 5. 
CHAPTER III

\section{DESCRIPTION, ANALYSIS, AND EVALUATION OF JOHN CARTER'S 1992 CRUSADE}

This chapter presents a description and evaluation of one of John Carter's major evangelistic crusades. This was conducted in Nizhniy Novgorod from May 9 to June 20, 1992.'

\section{Description of Nizhniy Novgorod}

Nizhniy Novgorod is situated 438 kilometres southeast of Moscow between the large Oka and Volga rivers. ${ }^{2}$ One of the oldest cities of Russia, Nizhniy Novgorod was founded in 1221 and was annexed to Moscow in $1392 .{ }^{3}$ In 1932 the city's name was changed to Gorky in honor of Maksim Gorky, the Russian writer. In 1991 the city returned to its original name: Nizhniy Novgorod. The Nizhiny Novgorod region occupies an area of 28,900 square

${ }^{1}$ The description of this crusade is collected from three major sources: Michael Morar, the researcher, who participated in the crusade; and Antonyuk Alexander, the President of Volga Vasky Conference, who was directly responsible for the day-to-day affairs of this crusade. A report on the Crusade in the Adventist Review was the third source.

${ }^{2}$ G. M. Lappo, redactor, Goroda Rossii, Entsiklopedia (Encyclopaedia of the cities of Russia) (Moskva: Nauchnoe Izdatelstvo, 1994), 297-301.

${ }^{3}$ Ibid. 
miles or 75,800 square kilometers. ${ }^{1}$

\section{History}

This city was strategically placed "on the great Volga route from the Baltic to Central Asia. Several colonial expeditions were launched from the city of Nizhiny Novgorod by prince of Vladimir, Yury Vsevolodovich, Ivan III the Great, and Ivan IV the Terrible." 2

Two major historical events had great impact on Nizhiny Novgorod. These were the Russian conquest of the Volga in the mid-sixteenth century and the two World Wars.

\section{Economy}

Nizhniy Novgorod developed rapidly. By 1817 it had become one of the greatest trading centers through its "annual trade fair which attracted traders and goods from across Europe and Asia." ${ }^{3}$ Trade in furs, which were obtained in the forests of Northern Russia, was the prime reason the city became prosperous.

Economic activity is the single most important factor that has given impetus to the growth of Nizhiny Novgorod. River routes provided easy, cheap, and fast transportation systems. Today Nizhiny Novgorod is the focus of excellent communications

${ }^{1}$ The New Encyclopaedia Britannica (1991 ed.); s.v. "Gorky."

${ }^{2}$ Ibid.

${ }^{3}$ Ibid. 
by river, road, rail, and air. ${ }^{1}$

Seventy percent of Russian industries are found in Nizhniy Novgorod. ${ }^{2}$ Many industries are located in this city today, such as the manufacturing of cars, ships, airplanes, instruments, television sets, metal, chemicals, and wood and leather products. There are also food processing industries. ${ }^{3}$

The economic needs of this city and its industries require professionals trained in various trades. Skilled workers are recruited from all over the country. The economic activities provide opportunity for upward mobility of workers. Many traders come from all over Russia to sell raw materials and buy finished goods for resale.

Population, Language, and Culture

The population of Nizhniy Novgorod is $4,467,000 .{ }^{4}$ Such a large urban population allows for great cultural dynamism. The majority of the population speak Russian. High mobility in Nizhniy Novgorod has brought some people groups who speak other languages such as Ukrainian, Moldavian, and others.

Nizhniy Novgorod also serves as a custodian for Russian culture. The fundamental features of Russian architecture were

${ }^{1}$ Ibid.

${ }^{2}$ Lappo, $\quad 297-301$.

${ }^{3}$ Ibid .

${ }^{4}$ Ibid. 
developed in this city. "The sixteenth-century Kremlin and seventeenth-century Archangel Cathedral remain in Nizhniy Novgorod as the finest examples of medieval Russian architecture."1

\section{Education}

As can be expected, the number of educational institutions in Nizhniy Novgorod is very high. The literacy level of Russia as a whole is 98 percent. ${ }^{2}$ Educational institutions for higher education in the city include the main university, a technical university, and institutes for music, medicine, engineering, transportation, foreign languages, and teacher training. ${ }^{3}$ Several theaters within the city impact on the culture of the people. Some of the theaters in Nizhniy Novgorod include the children's theater, the drum theater, and the opera theater. In addition there are many different museums. ${ }^{4}$

\section{The SDA Church in Nizhniy Novgorod}

The first SDA Church in Nizhniy Novgorod was established in 1909. In that year, the Russian Committee of SDA sent Yan Pahla, a German Bible worker, to Nizhniy Novgorod. When he arrived, he met twenty members.who were having private, family Sabbath worship

${ }^{1}$ The New Encyclopaedia Britannica, 374.

${ }^{2}$ Johnstone, 467 .

${ }^{3}$ Lappo, 297-301.

${ }^{4}$ Ibid. 
services in their homes. All twenty were skilled German workers. ${ }^{1}$ Between 1911 and 1912 the SDA Church in Nizhniy Novgorod wrote a letter to the city authorities asking for permission to register the church. The constitution at that time provided some limited religious liberty. The government officer responsible for religious affairs gave permission to organize the church and twenty people came together. Yan Pahla was appointed as pastor and Bible worker. When the permission was granted, the officer wrote on the document that no proselytizing was to be done among Orthodox Church Members. ${ }^{2}$ That meant no public evangelism was allowed to take place at that time.

However the church ventured to try public evangelism. Such an adventure was possible because the majority of members were foreigners and the church pastor was also a foreigner. The first recorded evangelistic crusade by the SDA Church in Nizhniy Novgorod was conducted in 1912-1913. This crusade was attended by many people, including members of the Orthodox Church; fifteen people were baptized. Government officials continued to monitor the evangelistic activities of the SDA Church. ${ }^{3}$

At another time, the government officer responsible for

${ }^{1}$ Nizhniy Novgorod, State Archives, 1911-1913; report written by Pastor I. Andreev of Nizhniy Novgorod SDA Church who read the document and sent the report on January 7, 1997. Now access to the State Archives is closed.

${ }^{2}$ Ibid.

${ }^{3}$ Ibid. 
religious liberty in the state gave orders to the mayor of Nizhniy Novgorod city to visit the SDA Church and write a detailed report of all that was going on, noting those who attended the church. The officer's report pointed out that the only local people who attended the church were one venikonov and his family and some small children. ${ }^{1}$ Public crusades and church services attracted the attention of government officials, making them inappropriate strategies for reaching out to the local Russian population.

Government officials were not the only obstacles to public evangelism in Nizhniy Novgorod. There is also evidence that the Orthodox Church opposed the missionary zeal of the SDA Church there. Between 1911 and 1913, one of the Orthodox priests reported that the SDA Church was sowing bad seed in the minds of Orthodox people and was bent on destroying the orthodox church. ${ }^{2}$

\section{Public Evangelism Explosion}

Today Adventism is on the move in Nizhniy Novgorod. Marilyn Thomsen has clearly summed up what has occurred in the city:

In a Russian city where Communists tried to obliterate the name of God, an Adventist evangelist recently held possibly the largest baptism the country has seen in a thousand years. In this city of Nizhniy Novgorod (formerly called Gorky) where Adventists once suffered persecution, Russian soldiers chauffeured evangelist John Carter to the opening meetings. ${ }^{3}$

${ }^{1}$ Ibid.

${ }^{2}$ Ibid.

${ }^{3}$ Marilyn Thomsen, "The Gospel Opens Doors of an Isolated City," Adventist Review, August 20, 1992, 6. 
Only two years earlier, in 1990, the SDA Church in Nizhniy Novgorod had 200 members. On June 20, 1992, 2,520 people were baptized and added to the church as a result of John Carter's crusade.

John Carter's 1992 baptism was soon followed by a series of baptisms, with over 1,000 baptisms taking place during his 1993. visit, and over 500 baptisms during his 1996 visit to Nizhniy Novgorod." Additional crusades were conducted in the city between 1994 and 1996 by other evangelists. Russian as well as foreign evangelists from the United States led out in these crusades. ${ }^{2}$

\section{Church Growth}

As a result of these evangelistic crusades, E. Parashuk reported gains in both number of churches and church members in Nizhniy Novgorod. ${ }^{3}$

The number of churches increased by 950 percent from two in 1990 to nineteen by the end of 1996. During this same time the number of members grew 1,428 percent from 236 to 3,371 . This is reflected in table 9 .

${ }^{1}$ Alexander Antonyk, personal communication, DATE??.

${ }^{2} E$. Parashuk, Report of Second Meeting of Volga Vatsky Conference, Nizhniy Novgorod, January 9-11, 1997.

${ }^{3}$ Ibid. 
TABLE 9

\begin{tabular}{ccc} 
NIZHNIY NOVGOROD, GROWTH OF CHURCHES AND CHURCH MEMBERSHIP \\
\hline \hline Year & Members & No. of Churches \\
1990 & 236 & 2 \\
1993 & 2,405 & 4 \\
1994 & 2,665 & 12 \\
1995 & 2,808 & 15 \\
1996 & 3,371 & 19 \\
\hline
\end{tabular}

Source: E. Parashuk, Report of Second Meeting of Volga Vatsky Conference, Nizhniy Novgorod, January 9-11, 1997.

Mass Media Evangelism

The establishment of the Three Angels Message ( $3 \mathrm{ABN}$ ) Television Center in Nizhniy Novgorod contributed to the church growth recorded in the city. The 3 . $A B N$ bought a sports complex and constructed a hall for producing TV programs, as well as purchasing a conference hall seating 1,300 people and a fully equipped cafeteria. The Conference offices are also housed in the same complex.

\section{Description of Carter's Crusade}

The Evangelist

John Carter is an ordained Seventh-day Adventist pastor, employed by the Southern California Conference in the United States of America. Before conducting his crusade in Russia, Carter had conducted successful evangelistic crusades in the Philippines and in Africa. He came to Russia with a highly credible background. 
How It All Began

John Carter had visited Moscow and had wanted to organize a major crusade in that city. However, another major crusade had already been scheduled for Moscow and the Russian church leaders advised John Carter to look for an alternative city. At that time, the Volga Ural Conference, now called the Volga Vatsky Conference, was glad to accommodate John Carter in Nizhniy Novgorod, one of its major cities.

The process that Carter used to select the city of Nizhniy Novgorod as the center for his crusade met several criteria for field selection as outlined by Dayton and Fraser. ${ }^{1}$

1. Knowledge about the target group. Carter made a site visit to Russia to familiarize himself with the situation. During his visit to Russia, Carter gathered information about Russians and the city of Nizhniy Novgorod. This fact was evident because Carter designed advertisements. which demonstrated great familiarity with the needs of the target group. The overwhelming response of the public to the advertisements resulted in Carter's holding three sessions on the first night. Later, Carter carried out a study which indicated that the advertisements had attracted the public.

2. Need for evangelizing the targeted group. Carter did not need to add another voice to the crowd of evangelists who had

${ }^{1}$ Edward R. Dayton and David A. Fraser, Planning Strategies for World Evangelism (Grand Rapids, MI: William Eerdmans, 1980), 91. 
already planned to target Moscow. Instead, Carter decided to go to Nizhniy Novgorod city in the Volga Ural Conference, which had not been targeted by any foreign SDA evangelist.

3. Availability of personnel and resources. Carter had access to financial resources, but in selecting his field, local resources such as personnel, venue, transportation, and organizational support were essential. The Volga Ural Conference extended maximum support because it was not involved in any major crusade and was able to offer whatever resources it had at its disposal. Carter did well to secure local input for the success of the crusade.

4. Access to the field. Carter felt a burden for the Russian people who had been shut behind high political walls for over seventy years. The prevailing conditions required that the local authorities grant permission to Carter, a foreign evangelist, to propagate Christian beliefs. This was the first time that the government officials of Nizhniy Novgorod had received a request of this nature. Understandably, it was not easy for them to make a decision on such a request, for these were the same officials who had strictly implemented the old constitution, which had sought to suppress religion.

The Conference found it very difficult to get the required permission for John Carter to conduct the crusade. After trying many times without success, the Conference appealed to the churches to pray specifically for the granting of official permission by the regional authorities. Finally permission was 
granted and there was great relief among church leaders at all levels of the Russian SDA Church: The local church got positive encouragement as their prayers were answered.

After the field (Nizhniy Novgorod) had been identified, the city was surveyed and some time was spent consulting with the Conference officials. The Conference had never hosted a crusade of the magnitude that was envisioned by Carter and it was not easy for them to anticipate what to expect from this crusade. Carter and his crusade manager worked hard to help the conference to know what was expected of them and also to secure their commitment to the crusade. In due course, a crusade plan was chalked out and the Conference took formal action to place a service call to John Carter to come and conduct a major evangelistic crusade within their Conference in the city of Nizhniy Novgorod.

The call was passed through regular channels. The Conference officials forwarded the service call to the Russian Union, EuroAsia Division, the General Conference, the North American Division, the Pacific Union, and finally the Southern California Conference. John Carter was now invited to come to Russia to conduct a major crusade.

The procedure used to secure administrative clearance for John Carter's crusade ensured the support of administrators at all levels of the church organization.

The crusade was backed by leaders from the evangelist's home country as well as by leaders in Russia. This elaborate and 
sometimes laborious administrative clearance facilitated networking between John Carter's home church in the USA and the new churches in Nizhniy Novgorod.

Involvement of church administrators at all levels of the church structure in Russia enhanced local ownership of the crusade. Although John Carter had initiated the idea and made an offer, the Russian Church processed a service call for him to come and conduct their evangelistic crusade. At the end of the crusade there was no question about the entity to which the newly established churches belonged. There was no question as to who was responsible for finding pastors for the new churches. All areas of support belonged to the local Conference, especially the support required for developing and discipling the new church. The Conference was, in principle, responsible for nurturing the new church members from the evangelist to the local church. When conferences or churches invite evangelists to come to their field, they should be prepared to play a major role in preventing apostasies and backsliding. New members need a conducive environment for spiritual growth and it is only the local Conference and local church which can nurture and develop the new members joining the church as a result of an evangelistic campaign.

$$
\text { Timing of Carter's Crusade }
$$

Carter's crusade was conducted between May 9 and June 20 , 1992. This was a good time for holding a crusade as it coincided 
with summer vacation. The timing was also ideal politically, because the old Russian Constitution with all its restrictions regarding religion had just been dismantled and all religious groups were free to evangelize anywhere, anytime.

\section{Preparation and Organization}

John Carter was dealing with a Conference which had little knowledge of the basics of an evangelistic crusade on the scale that he was planning. This limitation must have had some influence on the organizational procedures which Carter adopted.

Carter, together with the Conference officials, organized a crusade committee at the conference level. Conference officials were given tasks, and a local crusade manager was chosen from among the Conference officials. The task of organizing the church was left in the hands of the Conference committee. There is evidence that this arrangement worked and provided solutions to many obstacles which could have come up. This first campaign to be conducted in the Conference had a double purpose. Not only would it bring converts to the church, it would be a model from which pastors and Conference administrators would learn.

The process that Carter used to prepare for the crusade did not put much emphasis on the role of the local church. Success or failure for the preparation for the crusade was left in the hands of the Conference. The involvement of the Conference was critical, since the evangelist could not make frequent visits to 
the field. The Conference, which had invited the evangelist, was made fully accountable for supervising and monitoring each stage of preparation.

By organizing the Conference to spearhead preparation for the crusade, Carter provided much needed hands-on training for the Conference officials, who had never had this experience. At the end of the crusade, the Conference had a team of experienced resource persons who could now advise other pastors.

One of the major criteria of successful evangelistic crusades is the degree to which the local church is involved in the planning, execution, follow-up, and evaluation of the crusade. However, for this first crusade it was also necessary for the church administrators to give their support and guidance to the local church since no one had previous experience with large evangelistic meetings.

Today, the situation in the Volga Vatsky Conference has changed. Several crusades are often conducted at the same time in different parts of the Conference. Conference administrators cannot be expected to play a key role in preparing the church and the field for evangelism.

The crusade committee that organized Carter's crusade did its best to involve the church members. The Conference faithfully and successfully organized the churches for active participation. The committee motivated the church members through sermons, constant update of progress, and organization 
and training of laity for extensive visitation and the distribution of invitation handbills. However, all decision making was done by the Conference, and the local church was a passive participant.

As soon as government permission was granted, church members were assigned their territories, so that they could invite people to the crusade. The territory was carefully mapped, divided into sections, and the streets in each section were identified. Each of the two churches in Nizhniy Novgorod city was given its own territory. Each member was assigned to distribute personal invitations to each house on a given street. One hundred thousand specially printed invitations were distributed with the help of church members who were enjoying, for the first time, the freedom to propagate religion.

The two SDA churches in Nizhniy Novgorod fully co-operated with the Conference-led crusade committee. A top-to-bottom administrative approach was used, in which all plans were given to the churches. This worked well in Carter's first crusade in this city, as this was something new to these churches and a sense of curiosity and excitement prevailed.

Carter's crusade manager did an excellent job to ensure that every aspect of the crusade was planned and implemented according to plan. When the crusade started, a crusade committee was responsible for the day-to-day running of the crusade.

However, no proper plans had been made to ensure that this 
local organizing committee could extend its term beyond the twenty-six nights. The end of the crusade signaled the end of the mandate of the committee. If, as observed by Harold Bauman, "bringing lost people to the Savior means more than winning individual souls," then the services of a local crusade committee should extend not only several months before the crusade but also several months after it. Just as there had been a need to organize local churches into witnessing before the crusade, there was even more need to organize the church to disciple those who had found their new faith.

The noninvolvement of the local church in the detailed planning and financial affairs of the crusade created room for suspicion and mistrust between the laity and church leaders. A separate finance committee should have been set up with a few church members participating. The Conference crusade committee could have organized the church into several committees and given them greater opportunity to participate in all aspects of the crusade.

\section{Prayer Groups}

Although there were no prayer groups targeting these meetings, the whole church was asked to pray. Carter also wrote letters in which he asked for prayers. The crusade created a

${ }^{1}$ Harold E. Bauman, "Goals of Church Growth," in Missions, Evangelism and Church Growth, ed. Norman Kraus (New York: Herald Press, 1980), 141 . 
great opportunity for the church to learn the art of praying and to witness God's answering their prayers. Joe Ford and Robert M. Saul said the following about prayer:

Prayer is the forgotten force in evangelism today. Few witness training courses devote major emphasis to the necessity of prayer for fruitfulness in witnessing. Yet, all evangelism must begin with prayer. Unless the role of prayer in evangelism is recaptured, the church will only plod along in a world racing swiftly toward hell. Prayer is our greatest need. ${ }^{1}$

Andrew Jackson emphasizes that "we need to talk to God about people before we talk to people about God." ${ }^{2}$ Prayer is, therefore, an important aspect of public evangelism. When the president of the Conference was having difficulty obtaining permission from the local government leaders, he appealed to the two churches in Nizhniy Novgorod to plead with the Lord. This reminded the churches that prayer was the key to every door.

When finally the permission was granted, the church members were thankful to God for having answered their prayers. Now, the church was asked to pray for the success of the meetings. The meetings were a great success and served as evidence of the power of prayer.

Every day during the crusade the role of prayer was emphasized. Carter had a prayer group which met daily in the

${ }^{1}$ Joe Ford and Robert M. Saul, quoted in Edward C. Lyrene, "Prayer and Evangelism," in Evangelism in the Twenty-first Century, ed. Thom S. Rainer (Wheaton, IL: Harold Show Publishers, 1989), 90 .

${ }^{2}$ Andrew Jackson, A Heart for Others (Seattle: YWAM Publishing, 1992), 89. 
morning to pray for the crusade. Prayer was at center stage throughout the crusade. However, the end of the crusade also signaled the end of the prayer groups. If there had been separate groups composed of local church members, those groups could have continued to pray for the follow-up work.

The crusade provided great opportunities to develop each member's prayer life and to teach people how to pray, but this was not done. No prayer bands were formed to pray for specific requests. Members could have been taught the art of fasting and praying for each other, for the preacher, and for the audience.

Roger E. Hedlund reminds us that "world evangelization is a spiritual task and prayer is a basic required ingredient for fulfilling the Lord's commission to the church." ${ }^{1}$ There is no doubt that the needs of the church in Russia are great, but more than anything else, the members and new converts should have been taught how to pray. Herbert Kane says of prayer:

The evangelization of the world in this generation depends first of all upon revival of prayer. Deeper than the need for men, deeper far than the need for money, deep down at the bottom of our spiritless life is the need for the forgotten secret of prevailing, world-wide prayer. ${ }^{2}$

The people who remained after the crusade in charge of the follow-up needed prayers. Indeed, "all fruitfulness in service is the outcome of prayer of the workers, or of those who are holding up

${ }^{1}$ Roger E. Hedlund, The Mission of the Church in the World (Madras: Evangelical Literature Service, 1985), 239.

${ }^{2}$ Herbert Kane, Christian Mission in Biblical Perspective (Grand Rapids, MI: Baker Book House, 1976), 323. 
holy hands on his behalf." In the Carter campaign no effective plans were made to stress the importance of prayer after the crusade.

\section{Advertising}

John Carter had an elaborate advertising and marketing plan. So strong was Carter's belief in advertising that fully 30 percent of his total crusade budget was earmarked for this area. This was a shock to Conference officials. The twenty local Russian pastors, who had been invited to participate in the crusade, were equally surprised and described it as a great "waste."

While Carter spent a great amount on advertising, he also reaped greatly as thousands of people attended the meeting the first night as a result of the advertising blitz. Carter used five main channels to advertise the crusade: radio, television, newspapers, posters, and invitation handbills and billboards. Advertisement started one month before the crusade.

Radio advertisement

For a whole month prior to the meetings Carter advertised on the local radio. The invitation to come to John Carter's meetings was repeated every half hour from $7 \mathrm{a} . \mathrm{m}$. to 12 noon, time when many people were still in their homes. Again the announcement was aired from $6 \mathrm{p} . \mathrm{m}$. to $11 \mathrm{p} . \mathrm{m}$., in order to reach people at home. Venue and dates of the meetings were clearly specified.

\footnotetext{
${ }^{1}$ The Kneeling Christian (Madras: Gospel Literature Service, $1980), 20$.
} 
The radio advertising message featured John Carter himself and stressed topics dealing with archaeology. The spot announcements appealed to those seeking truth and created a lot of curiosity in the city.

\section{Poster advertisement}

John Carter had less trust in the effectiveness of posters to reach the masses. A very small fraction of his budget was used for printing posters. Five thousand large full-color posters were placed at strategic places so as to catch the attention of passersby. These posters featured the same archaeological theme.

The posters provided basic information about the crusade, such as venue, dates, and some of the topics. These posters were excellently designed and appealed to people of all age groups. The impact of the posters exceeded John Carter's expectations. Among those who accepted the third angel's message and joined the SDA Church, posters were identified as having the greatest impact on people's decisions to come to the meetings. Posters were also identified as the main source of information about the crusade by the majority of the people attending the meetings. Carter was later convinced that the posters were one of the most effective means to advertise the meetings.

Newspaper advertisement

Carter also advertised extensively through newspapers. An attractive ad of the crusade was always put either on the front 
or back page of the most popular newspaper. The color advertisement emphasized the archaeological theme. Attractive archaeological pictures were placed to attract the attention of readers. Basic information regarding the dates and venue of the crusade, as well as a few topics, was printed with enough detail to guide those who wished to attend the crusade.

Television advertisement

Carter made extensive use of local television channels to advertise the evangelistic crusade. In his television advertisements, Carter himself appeared on the screen wearing overalls, in different postures. Each of the postures was connected to some archaeological site, in Egypt or Israel. The focus of each television advertisement was not Carter but, rather, the archaeological excavation theme.

The television advertisements were screened during prime time and appeared at half-hour intervals. The ads created a lot of curiosity among the viewers and gave a lot of opportunity for the upper classes to learn about the crusade.

Billboard advertisement

Carter also used large billboards to advertise the crusade. All the basic information necessary for people to make decisions to come to the meetings was provided. The archaeological theme formed the background of the billboard advertisements. 
Invitations/Handbills

One of the main advertising modes used in Carter's crusade was the distribution of invitations. Full-color invitations were attractively designed and printed on good-quality paper with the archaeology theme providing the background. Enough information was given in the handbills to create curiosity and to influence people's decisions to attend the crusade.

With the help of the local church members who had been organized for the task, 100,000 invitations were distributed in flats, homes, and institutions within the city. Pastors instructed members what to do and how to distribute these invitations. The participation of every church member was enlisted and the method promoted ownership of the crusade among the membership.

\section{Entry Events}

Carter could have used various entry events before the crusade, so as to create publicity for the Seventh-day Adventist Church as a caring church. Entry events relevant to Russia-such as medical evangelism, service evangelism through ADRA, literature evangelism, Bible Correspondence Courses, or agriculture promotion-could have been used. Carter did not use any of these events and relied exclusively on advertisement through various media.

\section{The Crusade}

For most of the Conference officers who were taking part in 
this crusade, this was a first experience. Twenty local Russian pastors had been invited to the crusade so that they could have this experience as a field school of evangelism. Carter had a large team of volunteers from the United States of America who accompanied him, but language barriers were an obstacle to their usefulness: The Americans could not speak Russian and most of the Russian team could not speak English. The inexperience of the Conference leaders also limited the extent to which Carter's crusade manager could expect their participation.

Carter came a few days before the opening of the crusade and used his time effectively to establish rapport with the local leaders. Carter seems to have properly identified the key community leaders who could frustrate the crusade. Maximum cooperation was given to him from all levels of local leadership. Evidence of his ability to effectively mobilize the local government leadership became clear when Carter was chauffeured to the meeting hall for the opening night by Russian soldiers in an army vehicle. Again, at the end of the crusade, the local army, police, media, and transport department played crucial roles in making the baptism a national event, which appeared in the headlines across Russia in all forms of mass media. This could not have been possible if Carter had not done his homework well.

\section{First Day}

"Utter chaos" is the best phrase to describe the confusion 
that prevailed on the first night of John Carter's crusade. The organizers were caught off-guard. The impact of the one-month advertising blitz had been underestimated. Carter and his crusade manager had anticipated the filling of the 7,000-seat sports complex, but the inexperienced Russian organizing committee had not imagined such a scenario as. unfolded on that first night: a seventy-year-old man, breaking and crawling through a small window, a mob breaking the doors of the hall, a smoke bomb being thrown into the hall.

With 7,000 people inside the complex and more than 14,000 outside, all pushing, yelling, and trying to get inside, organizers prayed that the mob outside would not turn violent. Organizers were taken to task for cheating the people by advertising the meetings and failing to make adequate seating arrangements to accommodate those who responded. John Carter had outlined that in the event, that too many people turned up, he would hold two, three, or more sessions. However, the organizers had not made any plans to communicate this to the impatiently waiting people.

Those outside did not want to lose the opportunity to listen to God's Word. Those inside made desperate efforts to communicate about the other two sessions and give out books to pacify people's anger. Arrangements had been made to have Russian police and soldiers around the venue to enforce law and order. The presence of the men in uniform possibly helped 
restrain the people. Ali this time pastors prayed for God's intervention so that nothing would tarnish these meetings, the very first of their kind in Nizhniy Novgorod.

Inside the hall, the meeting proceeded. All doors were closed and soldiers manned them. However, the back door near the stage had not been tightly closed. Someone from outside threw a smoke bomb inside the hall, creating pandemonium among those sitting near the door. Carter remained calm. One of the young pastors took the device and threw it outside. Within a few minutes, all was calm and the meetings proceeded.

John Carter preached to three different audiences in three different sessions. This required successful time management on the part of the evangelist.

Carter did not allow the disruptions of the first night to distract him from his task of preaching the word of God. On the other hand, the local crusade committee made up of Conference staff never expected what they experienced. Most of these pastors panicked when the crowd abused them. Except for the calmness that prevailed in the hall, chaos prevailed elsewhere. Although the local leaders panicked, they did not neglect their duty. They remained outside with the crowd asking the people to be patient and attend the next sessions. Even though the crowd abused them, the pastors proceeded with their expected duties. The constant presence of the crusade organizers must have played a role in pacifying the crowd. 


\section{Daily Crusade Prograin}

Every morning, Carter met with the local crusade coordinator and his crusade manager at his hotel room. These three shared observations and suggestions. After this meeting, the whole crusade team met for prayer and sharing of ideas. These prayer sessions were attended by the Russian pastors and all the other members of the crusade team, which included a team of sixty volunteers from the Southern California Conference. Interaction between individual members of this group was limited by language barriers.

In connection with this crusade, a field school of evangelism was conducted for the Russian pastors by Graeme Bradford from the United States. Since few of the twenty Russian pastors had ever conducted an evangelistic crusade and most had never even attended one, the field school was designed to equip them to hold their own crusades in the future.

During the day, requests for visitation were followed up. The evangelist also visited selected persons. Some of the visits included preaching assignments such as when Carter was invited to preach to army soldiers and officers.

\section{$\underline{\text { A Cultural Aspect }}$}

Carter had made earlier visits to Russia and had sought to acquaint himself with Russian culture. His successful advertising campaign had been based on the knowledge of Russian 
culture. One aspect of the Russian culture which Carter did not take advantage of concerned the clothing of those who preach God's Word. In Russia the Orthodox priests use a special gown when preaching. Carter could have used such a gown to preach, but even more importantly, the pastors who were given special responsibilities in the crusade and who had special roles to play could have been given special gowns to identify them as God's representatives.

\section{Sermons}

The uniqueness of Carter's crusade was in his sermons. The first part of his evangelistic crusade was composed of five sermons dealing with archaeological topics. These archaeological topics differentiated Carter's crusade from those of other evangelists. Russian pastors describe the archaeological aspect of Carter's presentations as "the most powerful part"; many felt they were the most interesting part.

The archaeological aspect of Carter's sermons is basically aimed at establishing the authenticity of the Bible as God's Book. By the time Carter covered the first five sermons, he had talked about Egypt and Palestine. People were convinced beyond reasonable doubt that the Bible is indeed trustworthy. Many people commented that they had been moved by Carter's archaeological presentation. Another unique feature of Carter's presentations was that they were accompanied by visual aids. 
After the five archaeological sermons, Carter presented the usual topics covered during typical SDA public evangelistic crusades. Having already established the authority of the Bible, Carter shifted his emphasis to what the Bible says to us.

The other unique feature of Carter's sermons was his unusual emphasis on the anti-Christ. Carter's criticism of the Roman Catholic Church and the Russian Orthodox Church was clearly presented with no mincing of words. His boldness showed great courage and preparedness to face any consequences which might follow.

Carter's powerful criticism of the Roman Catholic and Russian Orthodox churches earned him and the SDA churches in Nizhniy Novgorod bitter enemies among the leaders of those churches. SDA pastors who attended the crusade and heard Carter clearly identifying the Orthodox Church felt that it would be more difficult for Carter to conduct another evangelistic crusade in the same area after he had publicly criticized other denominations.

Many pastors felt that Carter's powerful sermons, which had openly criticized the Russian Orthodox Church, would unnecessarily invite premature persecution, opposition, and disruption from the Orthodox Church leaders and their staunch supporters. Their fears have proved true.

\section{Seating Arrangement}

Carter divided the hall into sections and assigned pastors 
to each section of the hall. The audience could then channel their questions and requests through these pastors. There was no method of assigning the same people to the same section each day, but at least this method allowed for manageable groups to be supervised by the pastors. This method also allowed for an accurate attendance count each day.

\section{Distribution of Literature}

During the course of the meeting, literature was given out as an incentive to attend. Some was given out merely for attending regularly for seven meetings. Bibles were given to those who were baptized. Altogether 25,000 Bibles were given out during the crusade.

\section{Baptism}

In response to a call for commitment to baptism, people responded without hesitation and literally ran to the front. More than 5,804 people signed up for baptism. ${ }^{1}$ Elaborate plans were made for conducting the baptism in the Volga River.

The baptismal site had been made ready with the help of Russian soldiers who had prepared twelve tents as dressing areas. With army and police vehicles in front of the procession and sirens wailing and police stopping all traffic from all directions, the baptismal procession moved on. Following the

\footnotetext{
${ }^{1}$ Thomsen, 6 .
} 
police vehicles was a bus with banners on either side with "JOHN CARTER CRUSADE" written in bold letters. After John Carter's bus came the bus with the pastors, followed by fifteen big buses carrying 2,520 baptismal candidates. Some of the candidates came in their wedding gowns. This baptism was unique and left an indelible mark on those who witnessed it.

Carter's call for baptism had been clear and straightforward. People responded, knowing exactly what they were being called to do. Formal preparation for the candidates had been organized, but this was not thorough enough. Many obstacles made efforts to prepare so many baptismal candidates less effective. A total of thirty-five baptismal classes was established, but these were not enough for more than five thousand candidates, and co-ordination of these thirty-five classes was very difficult. ${ }^{1}$

\section{Church Planting}

Even though Carter was an itinerant evangelist, he made efforts to provide a holistic ministry. Churches were planted and new pastors assigned to the churches. Carter not only established large new congregations, he also ensured that church buildings were built for the new congregations.

In order to meet the growing personnel needs in the Conference, Carter provided funds for training a group of new

\footnotetext{
${ }^{1}$ Ibid.
} 
church pastors for a period of three months. Carter's ministry was comprehensive in that he preached, baptized, built new churches, and trained new pastors for the growing churches.

\section{Follow-up Plans}

As a visiting evangelist, Carter could not have been expected to stay indefinitely. The task of follow-up was left in the hands of the Conference crusade committee and the local SDA pastors in charge of the new congregations.

John Carter's evangelistic crusade was a major breakthrough for Russia. He changed people's perception of the SDA Church from that of a sect to a movement with a worldwide agenda. Many unimaginable things happened during John Carter's crusade in Nizhniy Novgorod in Russia. The final result was 2,525 new members added to the church within a period of one-anda'half months.

\section{Analysis of Long-Term Results}

This analysis of the long-term results of Carter's crusade places emphasis on the three basic phases of public evangelism, as given by Abraham J. Jules: ${ }^{1}$

1. The pre-evangelism phase, which involves training, teaching, motivating, mobilizing, and leading the church into a spiritual revival

${ }^{1}$ Abraham J. Jules, "Seven Secrets of Successful Evangelism," Ministry, February 1996, 15. 
2. The public meetings, which constitute the engagement stage

3. The post-evangelism phase, which focuses on closing the back door through bonding, nurturing, and grounding, made possible when church members are involved in providing guardianship and mentorship to the new members.

The Theoretical Basis of Analysis

This analysis is based on the long-term objectives of evangelism. At the outset, it is important to properly define the word evangelism, which is the pillar of this analysis. The analysis presented in this chapter takes into consideration Michael Green's outline of what evangelism is not: ${ }^{1}$

1. It is not the same as filling in pews; it is not a numbers game.

2. It is not an occasional raid by a visiting celebrity who does the task for the local church.

3. It is not a matter of impassioned and repeated calls for decision unsupported by biblical teaching and unrelated to the contemporary needs of the people.

4. It is not an activity limited to ministers alone which involves merely preaching in a special building at a given time.

5. It is not an optional extra for Christians but a major. part of total obedience to God's command.

Spurgeon defined evangelism as "one beggar telling another

${ }^{1}$ Michael Green, "Evangelism," Ministry, January 1993, 12-15. 
beggar where to get bread." ${ }^{1}$ In simple words, evangelism is simply telling a fellow searcher how to find God. The uniqueness of Spurgeon's definition is pointed out by Michael Green when he says, "There is no way that an evangelist is any better or on any higher ground than the person to whom he is talking. The ground is level around the cross of Christ."?

William Temple's definition of evangelism has far-reaching implications.

To evangelize is to present Jesus Christ in the power of the Holy spirit, that men shall come to put their trust in God through Him, to accept Him as their Savior, and serve Him as their King in the fellowship of the church. ${ }^{3}$

Green observed that Temple's definition of evangelism points to these characteristics:

1. Evangelism is not just mission, but involves worship, too.

2. Evangelism has Jesus as the essence of the message and does not advance the claim of a church or an ideology.

3. Evangelism depends entirely on the work of the Holy Spirit and not methods, strategies, and gadgets.

4. Evangelism means cooperating with the church.

5. Evangelism means challenging people to decide to worship Jesus Christ.

6. Evangelism means making disciples, not for the evangelist,

${ }^{1}$ C. H. Spurgeon, quoted in ibid., 14 .

${ }^{2}$ Ibid.

${ }^{3}$ William Temple, quoted in ibid., 14-15. 
the church, or the preacher's organization, but for Jesus Christ. Ron Halvorsen presents other important aspects of what evangelism involves. He defines evangelism as "team work uniting the local church, the pastor, and the evangelist." ${ }^{1}$ The connection between evangelism and nurturing is emphasized by Roy Naden, who argues for the vital need to reconnect evangelism and nurture. According to Naden, itinerant evangelists who fail to take time to nurture new converts should have their ministry re-defined. ${ }^{2}$

The analysis presented in table 10 represents the perceptions of Russian church members and pastors collected through interviews and questionnaires. The highest percentage of agreement was on the need for prayer (90\%), for good advertisement (82\%), and for the pastor of the new church to work with the evangelist. Respondents also stressed organization (72\%) and music $(70 \%)$.

Table 11 gives a summary of people's perceptions of major reasons for the high number of backsliders or dropouts.

Table 11 shows clearly that lack of a sense of belongingness is perceived as a major reason for backsliding. Galina stele also found that doctrinal matters were not the major factor contributing to dropout, but rather lack of personal contact (see table 12).

${ }^{1}$ Ron Halvorsen, "Evangelism: Getting the Church Ready," Ministry, January 1993, 16-18.

${ }^{2}$ Roy Naden, "The Holy Spirit and Evangelism," Ministry, March 1993, 8 . 
TABLE 10

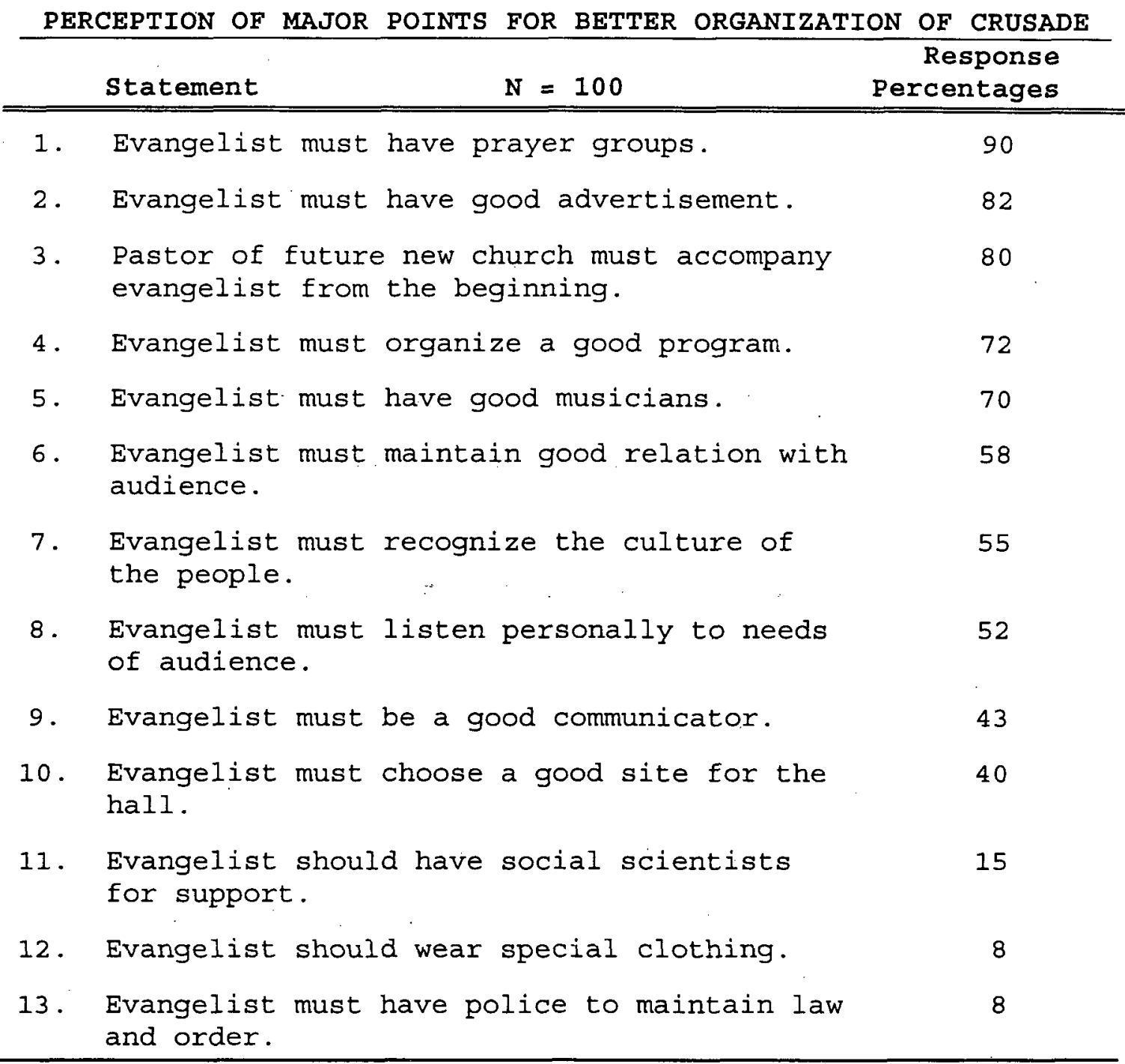

Analysis of Pre-Evangelism Phase

The procedure followed by Carter to secure permission to conduct the crusade was a long one with several positive longterm implications. Carter managed to establish long-term relationships with Russian church leaders at all levels, from the lowest to the highest. It was important for this to be done so 
that the new converts could be accepted into church fellowship. This initial administrative clearance facilitated future collaboration and further evangelism within the same field. Since that time, Carter has been able to conduct more crusades within the same Conference. If Carter had failed to establish good rapport with the church leaders, such collaboration would not have been possible.

Carter's proposal to the Conference had been well thought out and went far beyond mere addition of numbers to the church records. Church planting was a component of the plan, church buildings were erected, pastors were trained; and new pastors were appointed. Carter's crusade was the beginning of a string of events and not just a month and a half of meetings.

Carter was a visiting evangelist and was not able to mobilize and motivate the local church; it was, therefore, wise for him to deal directly with the local Conference. If carter had tried to deal directly with the local church, he would probably have been very frustrated. The Conference officers were held accountable to the Union, Division, and General Conference. In contrast, a local evangelist would have been expected to make direct contact with the local church, instead of the Conference. The whole task of organizing for the crusade was left in the hands of the Conference, with the local church left to be mere spectators. The Conference still could have involved the local 
TABLE 11

MAJOR REASONS FOR BACKSLIDING

\begin{tabular}{|c|c|}
\hline$N=100$ & Percentages \\
\hline Lack of follow-up program & 70 \\
\hline Lack of friendship & 64 \\
\hline Lack of spirituality in the church & 45 \\
\hline Lack of pastoral visits to new members' house & 39 \\
\hline Family opposition to one member going to church & 38 \\
\hline Lack of church building & 38 \\
\hline Short period of crusade (should be more than 4 weeks) & 38 \\
\hline Lack of proper education of the pastor & 37 \\
\hline Influence of the Orthodox Church & 33 \\
\hline Lack of pastor during first month after the crusade & 29 \\
\hline Lack of premarital counseling & 27 \\
\hline Conflict between church members & 26 \\
\hline $\begin{array}{l}\text { Lack of sociological information about people } \\
\text { during crusade and application of their gift in the } \\
\text { church }\end{array}$ & 25 \\
\hline Poor service in the church & 25 \\
\hline New pastor, who did not participate in the crusade & 19 \\
\hline Gossip and backbiting & 15 \\
\hline $\begin{array}{l}\text { Political illiteracy of population about religious } \\
\text { freedom and new laws }\end{array}$ & 14 \\
\hline Lack of special youth programs & 13 \\
\hline Lack of literature & 7 \\
\hline Lack of division of the church into subgroups & 6 \\
\hline Neglect of handicapped people & 6 \\
\hline Lack of telephone of believers & 4 \\
\hline Lack of literature for the blind & 4 \\
\hline Boring church service following old-fashioned ritual & 2 \\
\hline
\end{tabular}


churches in many organizational aspects but, again, at that time members and pastor alike had little knowledge of the proper concept of evangelism and the role of the local church. This was to be the first major crusade in the Conference so the Conference leaders could not take the chance of failure by putting a lot of responsibility on the local church.

TABLE 12

FINDINGS ON MEMBER DROPOUT

\begin{tabular}{|c|c|}
\hline Reason & $\begin{array}{r}\text { Response } \\
\text { Percentage }\end{array}$ \\
\hline Lack of personal contacts & 79 \\
\hline No knowledge of new members' problems & 69 \\
\hline Infrequent home visitations & 58 \\
\hline Natural results from mass conversions & 55 \\
\hline Absence of professional training for pastors & 42 \\
\hline Shortage of church pastors & 24 \\
\hline Lack of proper follow-up system & 23 \\
\hline
\end{tabular}

A great opportunity for training the church members was missed by denying them active involvement in detailed planning for the crusade. The Conference officers met frequently by themselves, deliberated on certain issues, decided on courses of action, and later instructed the churches. The effect of this faulty organizational process. would result in failure of future crusades, 
in which the Conference was again expected to play the key role. As more crusades were started in the Volga Vatsky Conference, the officers were not able to find time to be responsible for them all. The answer to this problem was for the local church to have been involved in planning for this crusade right from the start. The Conference officers should have played a supervisory role. Instead of the Conference, the local church should have been at the center of planning for Carter's evangelistic crusade. When the follow-up arrangements failed, it was because the local church had not been helped to make evangelism their number one business. Carter's well-planned advertising campaign had effects that went far beyond the crusade objectives. This became a major publicity event, not only for the crusade but for the seventh-day Adventist Church throughout Russia. The advertising gave 'witnessing members a reference point when talking about the SDA Church. Carter's advertising accomplished far more than what money could have bought for the whole church in Russia, and 82 percent of respondents affirmed that an "evangelist must have good advertisement" (see table 10).

The way personal invitations were distributed for Carter's crusade created opportunities for every church member to participate. Members were not told about the fact that continued visitation also would be critical after the crusade. Thousands of the people whom the church members had invited came to the meetings and some were baptized. However, members did not bother 
to revisit the people, to thank them for accepting their invitations, or to follow up on their decisions.

If members had been properly trained as to their role in visitation and the timing of the visitations, a solid foundation could have been laid down for effective follow up. The visitation plan was only for inviting the public to attend with no thought given to using the same people to nurture and disciple people in their assigned areas. In the future, visitation should be done as part of the overall follow-up program.

\section{Analysis of Public Meetings}

The fact that Carter had his vision set beyond the crusade was evidenced in his emphasis on establishing rapport with all leaders within the community. This was important and would greatly benefit the new churches. For example, the permission for acquiring land to build new churches was granted with few problems. Carter had clearly established the SDA Church as a credible organization. His success in demonstrating local approval and support of the crusade helped boost people's positive perception of the Seventh-day Adventist Church.

Carter's daily sermons had a far-reaching effect. The power and clarity with which they were delivered made a lasting impact on the minds of the people. The order of Carter's sermons, to some extent, was in line with the traditional SDA order of public evangelistic sermons. Carter's sermons were all Christ-centered 
but there were very few sermons on and about Christ. Carter, however, preached sermons about Christ more than most visiting evangelists whose sermons I have heard.

The need for sermons on Jesus, His life, His work, His death, His ministry while on earth, and about the plan of salvation is critical for Russia. Carter demonstrated that he realized this need, but he did not go far enough. Most evangelists would classify such sermons as children's Bible stories, but, for Russia, this is needed. Most evangelists spend much time and effort in Russia, teaching people what Christ requires of them, without teaching them who Christ is. Russians have little knowledge of Christ; thus preachers need to take time to identify Christ as Lord, and this calls for a slight deviation from the traditional sermon outlines for SDA public evangelistic crusades. This need cannot be met by the usual voice of Prophecy lessons because the emphasis of these lessons is to show the uniqueness of the SDA church as God's remnant.

Carter's powerful criticism of the Russian Orthodox Church also left lasting impressions on those who listened to him. He clearly drew a distinction between truth and error and left people to decide for themselves. The seed that Carter sowed will grow and if the local church continues to engage in extensive witnessing, it shall continue to reap the results of Carter's crusade.

Some felt that Carter was, perhaps, too critical and that this would hurt the church later because of opposition from 
Russian Orthodox Church leaders. Nevertheless, the church of God has always thrived under persecution and opposition.

There are several aspects of Carter's crusade which could have been done differently. If the seating arrangement had been done according to interest groups, it.could have formed a foundation for follow-up and setting up action teams. Although homogeneous grouping has many advantages, it is not practical with an audience of twenty thousand people who come to a crusade without prior registration. The majority of the audience came with friends, families, and spouses and it would have been very difficult to separate them in such a vast crowd. Carter randomly divided the auditorium into sections and this worked.

Carter also could have hired a sign-language translator to interpret the sermons for the benefit of the deaf who could have been invited to attend these meetings. For a city with a population of over four million, the number of deaf mutes within the city justified a sign interpreter. Lack of this service denied that group the gospel.

Literature distribution was haphazardly done. If a proper system of distributing the Bibles and other literature had been used, some people could have benefited from Bibles that were dishonestly claimed by others. The giving of Bibles was perhaps one of the greatest things Carter did for the audience. He left them with the greatest of all treasures, the Bible, and encouraged them to read it and learn more about God. 
The local pastors were not actively involved in the day-today decision-making process. The language barrier contributed to this lack of involvement with the result that as soon as the crusade was over and the Conference personnel went back to their work, there was no one to be in charge of nurture and discipleship. As a result, the follow-up program failed because the "owners" of the crusade had gone.

It was clear that Carter had a mandate to preach God's word and had no time to waste on what he felt were minor details. No time was given to feature local pastors so that they could be identified as members of his team and help the transition after the end of the crusade. Efforts were made, however, to give the local pastors opportunities to meet and visit the audience outside of the preaching time. Pastors were strategically placed within the audience and at the doors. This was helpful as the pastors had a chance to become acquainted with the audience even though they were not seen on the platform. Baptismal classes provided another opportunity for local pastors to establish a relationship with the audience and the new members. The actual baptism, again, presented an opportunity for establishing more relationships.

However, most of the local pastors who were involved in the crusade were not working in Nizhniy Novgorod, so they left as soon as the crusade ended. They had come to attend the field school of public evangelism and to learn how to conduct evangelistic crusades. When these pastors left, the newly 
baptized people were left with no familiar caretakers. It would have been better if local members around Nizhniy Novgorod had been used to establish lasting relationship with the audience. Such a strategy would have facilitated the follow-up work.

During the course of the meetings, the local pastors who were given specific assignments did not take advantage of the prevailing Russian culture, even though 55 percent of the respondents agreed that knowing the culture of the people was important. Russians have great respect for priests due to the Orthodox influence. Each night, time was set aside for the people in each section to ask questions through the pastors who supervised the sections. Most Russians believe that priests alone have the knowledge regarding religion and the Bible. Several of the pastors were asked whether or not they were priests, because the audience doubted the answers that were given. One of the pastors was asked whether he was a priest or not, and after telling them that he was a priest, an elderly person in the group stood up and asked his fellow group members to accept the answer since "priests do not lie."

In Russia, the term "Pastor" is strange. Spiritual leaders are culturally defined as priests. The position of priests as accepted among Russian culture is defined by Paul G. Hiebert.

A priest, on the other hand, receives his authority from the office he holds in a religious organization or church, rather than from his own personal charisma. The power to influence the supernatural lies in the institution and not in the person. . . As a spokesman for a religious group, 
he is often the intermediary, who speaks to the spirits on behalf of the people. ${ }^{1}$

The pastors in charge of the groups could have used gowns, too. Their authority over the groups would have been enhanced if they had put on gowns and their answers to the many questions asked would have been accepted without doubt. The pastors who manned the doors and kept the record of attendance would have found their task easier if they had put on gowns. Taking advantage of the culturally familiar use of a gown would have enhanced the acceptability of the pastors. According to stephen Grunlan and Marvin Mayers, people who minister in another culture must enter that culture. ${ }^{2}$ However, perhaps many Adventists also reflected Carter's stand on this issue because only 8 percent of the respondents felt that "having a special gown was a critical feature in crusade organization" (see table 10).

\section{Visitation Program}

There were many other objectives to be accomplished during the campaign period besides visiting interests. The local pastors who helped the team had to complete rigorous requirements as part of field evangelism training school and so did not have adequate time to spend on visitation. Although Carter had brought with him a

${ }^{1}$ Paul G. Hiebert, Anthropological Insights for Missionaries (Grand Rapids, MI: Baker Book House, 1983), 381.

${ }^{2}$ Stephen A. Grunlan and Marvin K. Mayers, Cultural Anthropology: A Christian Perspective (Grand Rapids, MI: Zondervan Publishing House, 1988), 22 . 
sixty-member team of volunteers from United States, communication barriers made it impossible for them to carry out a rigorous visitation program. Bearing in mind that more than twenty thousand came to the meetings every night during the first week, the logistics for an effective visitation program were limited by the lack of resources. The results of this crusade could have been even better if interests had been visited during and after the crusade. Local SDA laypersons should have been recruited and trained for carrying out a full-time visitation program. The full potential of the sixty volunteers from the United states could not be tapped for want of translators. The follow-up program was not adequately supported and coordinated, and this undermined the success of the crusade's long-term effects.

\section{Music}

Carter's crusade made use of music. Several groups were invited to present songs and prepare people's hearts to receive the message. What Roy Allan Anderson said a half century ago is still true: "The evangelistic choir has proved to be not only a means of bringing a blessing to the meetings generally but also a fruitful field of evangelism itself."

Starting a mass choir during the course of the evangelistic meetings could perhaps have helped attract people with musical

${ }^{1}$ Roy Allan Anderson, The Shepherd Evangelist (Washington, DC: Review and Herald Publishing Association, 1950), 511. 
inclinations. Nevertheless, the variety of music that was rendered during Carter's crusade was outstanding and enhanced the speaker's messages.

The use of congregational singing during song service was missing and this, together with a mass choir, could have been effectively used to establish an interest group to serve as a nucleus for a follow-up support group. A large number (70\%) of the respondents also perceived that evangelists must have good musicians to succeed.

Fisher noted the power of music in evangelism:

Besides the ministry of the words of the songs, one of the principle purposes of the song is to "weld" a collection of individuals into a congregation that is united in spirit and objective and receptivity and nothing has ever been devised that is more effective in doing that than getting people to sing together. ${ }^{1}$

\section{Seating Arrangement}

Carter did not have any social scientists within his team to help with seating arrangements and the establishing of interest and friendship teams. Only 15 percent of the respondents felt that this was essential at an evangelistic crusade (see table 10).

If Carter and a few of his crusade team members had met with members of the audience inside the hall every evening right after the meetings for prayer and counseling, this would have created a bond with the audience. Over 52 percent of the respondents felt

\footnotetext{
${ }^{1} \mathrm{C}$. William Fisher, Evangelistic Moods, Methods, and
} Messages (Kansas City, MO: Beacon Hill Press, 1967), 35-36. 
that an evangelist must listen personally to the needs of the audience (see table 10). However multiple sessions made this impractical during Carter's crusade.

\section{Field School}

The field school, which was conducted for the pastors during Carter's crusade, was very important. Most of these pastors had never conducted any evangelistic crusade. Most conducted their own crusades after this training. Carter knew very well that alone he could not evangelize the whole world. More laborers were needed to finish the work and so he made provision within his program to train others to do the same work he was doing. If Carter had included some laypersons in this training, the local pastors would have had someone to join them to help organize their own crusades.

\section{Time Constraints}

The time span of twenty-eight nights in which Carter conducted this major crusade was inadequate for people to move from atheism to Adventism. Such a process required far more time than was allocated by Carter. It is likely that some of the people who responded and received baptism were still atheists at heart. Not enough time was given to allow the seed to be established. The art of discipling calls for more time.

\section{Baptismal Arrangements}

The response to the altar call for commitment to baptism was 
overwhelming with close to six thousand people wishing to be baptized. Logistical support was far from adequate to deal with such a large group of candidates. Efforts were made to prepare candidates for baptism, but these efforts did not yield the desired results. There was no adequate place within the hall for separating thirty-five baptismal classes, which were established and conducted by twenty Russian pastors. Considering nearly six thousand candidates, each of the thirty-five classes was congregation on their own. Time was another constraint, because there was never more than an hour and a half between two preaching sessions. Between meetings the pastors who were supposed to prepare the candidates were busy ushering visitors and meeting with their assigned groups to answer their questions. Most of the preparation for baptism was therefore conducted by Carter himself after his sermons. This preparation was not enough.

Individual preparation of the candidates would have been preferable, but this was not possible due to the large numbers of candidates, which exceeded 2,500. Alternative arrangements could have been made for the candidates to be instructed fully afterwards, but it is always advantageous to instruct the candidates before the baptism ceremony.

Roy Allan Anderson suggests that candidates be instructed before their baptism.

The time to instruct converts thoroughly is before their baptism. At that time they are eager to learn, and the fires of their first love are burning brightly on the 
altar of their hearts. They are already making many spiritual and social adjustments. That truly is the time of all times to lay before them the full privileges and responsibilities of church fellowship. ${ }^{1}$

Even after new members have been baptized, George Vandeman advises that great effort must be made to surround them with every evidence of church care. ${ }^{2}$

Outstanding arrangements were made for transporting and baptizing the candidates. All ordained pastors were briefed on how to conduct the baptism and record the number of those baptized.

\section{Churches Planted}

Carter also planted churches for the new believers. This fulfilled the very purpose of conducting the crusade.

Establishing churches is a strategy which creates opportunities for building relationships and becoming involved in witnessing through several church activities. It is rightly said that Jesus "intended the church to move outward all the time in planting new churches." ${ }^{3}$

The goal of planting a church is to have a dynamic, growing, mission-minded church. Bonding should be encouraged between new

${ }^{1}$ R. A. Anderson, 257.

${ }^{2}$ George Vandeman, "The Short Campaign," Ministry, September $1995,26$.

${ }^{3} \mathrm{Cl}$ ive Calver, Derek Copley, Bob Moffett, and Jim Smith, $\underline{A}$ Guide to Evangelism (London: Marshall, Morgan and Scott, 1984), 51 . 
believers and other church members so. that "the sense of oneness in the body of Christ will happen." ${ }^{1}$

However, Carter established two large congregations having about one thousand members in each. Such large congregations were difficult to manage and allowed many to slip out the back door and disappear from fellowship. Instead of a few big churches, several small churches could have been established. Small churches allow for deeper fellowship and more relationships-the very things that help hold new members.

\section{Analysis of Dropout Factors}

The figures on membership gain and loss within the Volga Vatsky Conference (where Carter's crusade was held) between 1994 and 1996 appear in table 7. The dropout figures for that period are very high. Carter's 1992 crusade was the main factor behind the impressive gain in church membership. But it is also necessary to analyze the dropout figures for the Volga Vatsky Conference to find out how the Carter crusade could have contributed to such a high dropout rate.

A brief theoretical review of backsliding is, therefore, necessary in order to have a clear view of why dropouts occur. Monte Sahlin wrote about the seriousness of the dropout problem within the church:

${ }^{1}$ Sherwood G. Lingenfelter, Transforming Culture: A Challenge for Christian Mission (Grand Rapids, MI: Baker Book House, 1995), 198 . 
The challenge of church dropouts raises serious issues of responsibility, fellowship, and the effectiveness of our nurture activities. At a more profound level, it surfaces [as] even deeper concerns about the life and structure of the Adventist Church. ${ }^{1}$

There are basically three major reasons for membership loss. Cerna points out that, in a typical church; annually a church will lose 2-3 percent of members through transfer and that this percentage could be as high as 15-20 percent in an urban church. ${ }^{2}$ In the Volga Vatsky Conference, 11 percent of the membership was lost through transfer (see table 8). Backsliding or apostasy accounts for 2-6 percent of members in a typical church. ${ }^{3}$ The third source of membership loss is death, which accounts for 2 percent of loss of membership in a typical church." In Volga Vatsky Conference backsliding or apostasy accounted for 66 percent of dropouts while death accounted for 23 percent (see table 8).

Cerna identifies the main reason for backsliding as the "lack of permanent friendships, $"{ }^{5}$ and presents his solution to the problem:

I believe there are two basic factors in keeping people and assimilating members: (a) we must organize small

\footnotetext{
${ }^{1}$ Monte Sahlin, "Where Are Our Missing Members?" Ministry,
} May $1989,18$.

${ }^{2}$ Miguel Angel Cerna, "Win Them and Hold Them," Ministry, December 1993, 24 .

${ }^{3}$ Ibid.

${ }^{4}$ Ibid.

${ }^{5}$ Ibid. , 25. 
groups in which they can be nurtured and develop friendships; (b) we must teach them that as surely as there is a place in heaven for them, there is a place for them to work for God on earth. Small groups provide both a place for nurturing friendships and an evangelistic action unit. ${ }^{1}$

Dropouts from among the new members of Carter's crusade could have been expected to be many because large, new congregations were established without any small groups in which the new members could be nurtured. The new, large churches offered few opportunities for developing friendship. It would have been better if several small congregations of only two or three hundred people had been established, with each new member assigned to a small group fellowship.

Another problem was that, after their baptism, Carter's converts were not given any work to do. Much could have been accomplished if these new converts had been assigned work to care for their peers. A peer system, organized according to interest groups, could have worked better because of the large numbers. The newly appointed pastor was overwhelmed by the large number of new converts. There were too many "baby" Christians for a few leaders to care for.

Respondents were asked to identify major reasons for backsliding from a list of factors. "Lack of friendship" was identified by 64 percent of the respondents as a major reason for backsliding. Friendship takes place in smaller groups. Cerna's

${ }^{1}$ Ibid. 
observations about friendship and groups as the key to solving the backsliding problem are also shared by Russian SDA members. Unless a conscious effort is made to create friendship, dropout rates are bound to remain high after crusades. Even Stele found that 79 percent of her study group identified lack of personal contacts as a prime reason for dropouts. ${ }^{1}$

Opposition was also explored to find out whether the respondents perceived it as a major factor to backsliding in Russia. The "influence of the Orthodox Church" was perceived by 33 percent as contributing to backsliding, while 38 percent identified "family opposition against one member going to church" as a major factor in dropout.

Several other possible factors in backsliding were identified. The presence or lack of a church building was identified by 38 percent as a major reason. But Carter helped the new congregations build new churches; however, only two large churches were planted instead of several small churches.

The professional level of Russian pastors did not seem to be the major factor, in spite of the fact that most Russian pastors do not have seminary training. In her study, stele found that 42 percent identified lack of professional training as an important factor in dropout. ${ }^{2}$ In this study, 37 percent identified "lack of proper education of the pastor" as a major reason for backsliding.

\footnotetext{
${ }^{1}$ Stele, 107.

${ }^{2}$ Ibid
} 
Others (29\%) thought that dropouts were due to the lack of a pastor for the new church "during the first month after the crusade." In Stele's study, 24 percent thought that the shortage of church pastors was the main reason for member dropout.

Nineteen percent indicated that assigning a "new pastor who did not participate in the crusade" was a major factor in dropout. Only 6 percent (see table 11) said that the "lack of division of the church into subgroups" was a major reason for backsliding. This response may only reveal the respondents' lack of proper understanding of group dynamics.

Carter's action plan for the evangelistic crusade made provision for the appointment of new pastors for the new churches. These pastors were appointed at the end of the crusade. Pastors were given training daily during the crusade to improve their professionalism. Carter also provided funds to the Conference for the upgrading of the new pastors by the Conference for a period of three months. Such training would help improve the quality of pastoral services in the church, as 25 percent had indicated that poor services in the church were a major factor in backsliding. Creation of an effective follow-up system, which includes visitation and meeting the fellowship needs of the new converts, could have been a partial solution to the problem of dropout. ${ }^{1}$ The challenge that faced Carter, as well as other evangelists,

${ }^{1}$ Gary Kuhne, "Follow-up: An Overview," in Discipleship, ed. B. Hanks and $W$. Shell (Grand Rapids, MI: Zondervan Publishing House, 1982), 111. 
was how to establish an effective system, involving the whole local church, that would be able to support new members long term. Delaying baptism was yet another strategy which could be tried in Russia during evangelistic crusades. When baptism is conducted immediately after the crusade, Bible classes should continue as part of the major crusade.

When Carter left Nizhiny Novgorod, such a program had not been established. Planning the crusade took a great deal of effort and resources and the same painstaking effort should have been taken to plan a strong follow-up program. 
CHAPTER IV

\section{DEVELOPMENT OF AN IMPROVED STRATEGY \\ FOR PUBLIC EVANGELISM IN RUSSIA}

This chapter presents a strategy for public evangelism in Russia. However, before a strategy can be workable, a proper concept of evangelism, which is often missing among church members in Russia, must be developed. The strategy is presented as a set of three processes: preparation, the actual crusade, and follow-up.

\section{The Concept of Evangelism}

Jesus clarified the purpose of calling disciples when he declared, "As my Father hath sent me, even so send I you" (John 20:21). The great Gospel Commission was given for all. In it Jesus commanded His disciples to make disciples. Then he added, "I am with you always, even to the end of the world" (Matt 28:1820). Not only did Jesus command His followers to go out to all the ends of the earth, but He promised them His presence through the Holy Spirit (Acts $1: 8$ ).

\section{Ellen White's Concept of Evangelism and Adventist History}

Ellen $G$. White has made a significant contribution towards understanding evangelism in the Seventh-day Adventist Church. 
She pointed out that belief in the imminent return of Christ was to be the driving force behind evangelism:

The words of Jesus Christ are spoken to us living down here in the close of this earth's history. The nations are in unrest. Times of perplexity are upon us. Rebellion to the commandments of God seems almost universal. Amid the tumult of excitement with confusion in every place, this is a work to be done in the world. ${ }^{1}$

White did not perceive evangelism as the domain of evangelists alone. Instead she emphasized the need for involving church members in evangelism and wrote that

churches are to be organized and plans laid for work to be done by the members of the newly organized churches. This gospel missionary work is to keep reaching out and annexing new territory. . . The circle is to extend until it belts the world. ${ }^{2}$

In the early history of the Adventist Church, the dominant focus of the evangelistic thrust was aimed at the "little flock" which was to be warned of what was soon to befall the earth. ${ }^{3}$ This concept of evangelism was church-centered and designed to benefit members. However, this narrow perception of evangelism started to change in the period between 1860 and 1863 , when the purpose of evangelism became to reach out to new fields with God's warning. This was clearly reflected by E. G. White when she wrote that the purpose of organization in the church was

${ }^{\mathrm{E} E l l e n} \mathrm{G}$. White, Evangelism (Washington, DC: Review and Herald Publishing Association, 1946); 18.

${ }^{2}$ Ibid. , 19 .

${ }^{3}$ Thom W. Fowler, "The Church and Evangelism" (M.Div. Project, Andrews University, 1974), 23. 
to provide for the support of the ministry, for carrying the work into new fields, for protecting both the churches and ministry from unworthy members, for holding church property, for the publication of the truth through the press.

The SDA global concept of evangelism had undergone a major revolution by $1930 .{ }^{2}$ Even then, there was no emphasis on the church becoming on evangelistic center, but the purpose of the organization was expanded to include training and organization of members.

By the 1970s the concept of evangelization expanded and became synonymous with "campaign." The Evangelism Handbook defines the "Evangelistic Campaign" ${ }^{3}$ as "the concentration of effort designed to bring about personal encounters with Jesus Christ." ${ }^{4}$ This concept of evangelism is viewed as the work of a specified time when an evangelist conducts his annual campaign. The evangelism ritual in this context is comprised of specific steps, spelled out in the SDA Evangelism Handbook: "preparation of territory, advertising, organization, conducting the meeting, getting decisions, baptisms and follow-up." 5

${ }^{1}$ Ellen G. White, Testimonies to Ministers (Boise, ID: Pacific Press Publishing Association, 1962), 26.

${ }^{2}$ Fowler, 24 .

${ }^{3}$ Raymond H. Woolsey, Evangelism Handbook (Washington, DC: Review and Herald Publishing, 1972), 7.

${ }^{4}$ Ibid., 11

${ }^{5}$ Ibid. , 9. 
Drawbacks to the Traditional Concept
of Evangelism

There are several drawbacks in the traditional concept of public campaigns, but the greatest of these is the high rate of backsliding. Traditional evangelistic crusades often result in little sustained interest in the people baptized, as the church quickly slides back into its normal activities immediately after the crusade. People who join the church as a result of crusades are not given enough time to adjust to the new "Christian" culture. Grunlan and Mayers clarify the process of backsliding in the context of culture.

When an individual leaves his or her own culture with its familiar customs, traditions, social patterns, and way of life, the individual quickly begins to feel like a fish out of water and must either begin to adjust to the new culture or be tossed and buffeted by it until he or she finally succumbs to exhaustion and suffocation. ${ }^{2}$

People who respond to the evangelistic crusades can move "either toward empathy, acceptance, and identification or toward culture shock and rejection (and possible recovery)."2

Identification can only be possible when the new believers become part of the church fellowship.

While itinerant evangelists may contribute to some of the problems of crusade evangelism, Ellen White does not oppose their work. She wrote of Paul: "From city to city, from country to country, he journeyed, telling the story of the cross, winning

${ }^{1}$ Grunlan and Mayers, 22.

${ }^{2}$ Ibid. , 23 . 
converts to the gospel, and establishing churches." ${ }^{1}$ she notes that there are some ministers (Carter seems to be one of them) who are able to attract large audiences: "The Lord has given to some ministers the ability to gather and to hold large congregations." 2

Itinerant evangelists have a role to play in the Russian SDA Church today. Evangelistic crusades conducted in halls, like the one by Carter, are encouraged by E. G. White, who advised that "large halls in our cities should be secured that the third angel's message may be proclaimed by human lips" and "thousands will appreciate the message." ${ }^{3}$ A stamp of approval on the SDA traditional approach to evangelism is implied by White's comprehensive coverage of various instructions for holding evangelistic crusades including aspects such as planning for public campaigns and organizing for evangelistic meetings. ${ }^{4}$

Model Concept of Evangelism for Russia

A proper concept of evangelism is missing among most Adventist churches in Russia. In some crusades, the local church does not play a major part. Some members feel this it is the pastor's work. In one crusade, I had the experience of doing all

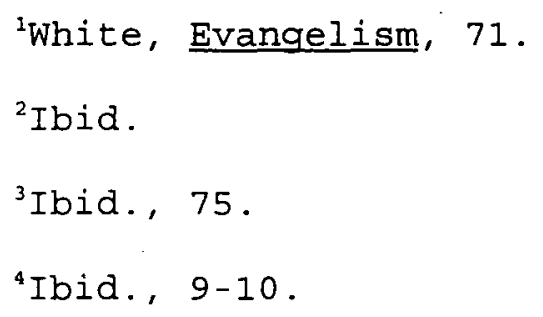


the advertising, distributing the invitations and posters with only the help of the local pastor. The local church members did not want to participate. Several other pastors have had similar experiences. Evangelists should not think that the local church would automatically do the assigned work.

A model concept of evangelism is presented by Ellen G. White. Some critical elements of her concept of evangelism include the following:

1. Every member is to be an evangelist. Christ's great commission is extended to all members. White says, "We are bidden to go forth as Christ's messengers, to teach, instruct, and persuade men and women, to urge upon their attention the word of life." Even "young men and young women" are to be recruited and trained to do evangelistic work. ${ }^{2}$

2. Needs assessment of the targeted groups is an essential part of effective evangelism strategies. White encouraged the setting up of a commission to study the special "needs of the cities and put forth decided efforts to advance the work." ${ }^{3}$

3. People from all socioeconomic backgrounds are to be targeted in evangelism. Urban as well as rural populations are to be reached. White encourages Christian families to relocate

\footnotetext{
${ }^{1}$ Ibid. , 15.

${ }^{2}$ Ibid. , 24

${ }^{3}$ Ibid. , 38
} 
into towns and villages, and raise the standard of truth, that God may have His witnesses scattered all over the land, that the light of truth may penetrate where it has not yet reached, and the standard of truth be raised where it is not yet known. ${ }^{1}$

4. All evangelistic work needs proper planning. White points out that "the great Teacher laid plans for His work."2 Referring to evangelistic work, White further says: "Wise plans are to be laid, in order that such work may be done to the best possible advantage." ${ }^{3}$

5. Accountability structures are to be built into the evangelistic plans. White emphasizes strict economy and proper budgeting in evangelistic work and warns against going "forward blindly in the investment of means that they have not and know what where to obtain." 4 The accounting and preaching roles are to be separated, and White advises that the management of financial matters rests on others than "those set aside for the work of preaching the gospel." 5

6. Field training schools are to be an essential component of evangelism crusades. Here people "become as apprentices to learn the trade of laboring for the conversion of souls." 6

$$
\begin{array}{ll}
{ }^{1} \text { Ibid., } & 52 . \\
{ }^{2} \text { Ibid., } & 53 . \\
{ }^{3} \text { Ibid., } & 59 . \\
{ }^{4} \text { Ibid., } & 85 . \\
{ }^{5} \text { Ibid., } & 92 . \\
{ }^{6} \text { Ibid., } & 107 .
\end{array}
$$


7. Evangelistic sermons should be properly prepared, with "less controversy and far more presentation of Christ."1 Judgmental sermons are to be avoided and authorities are to be respected. As White says, "the fewer attacks we make on authorities and powers, the more work will we do for God."2

8. New converts should not be rushed into baptism without thorough preparation. White clarifies that "there is need of a more thorough preparation on the part of the candidates of baptism." ${ }^{3}$

9. Proper follow-up plans must be designed and implemented to hold the new converts. White views this phase as even more important than the first." She notes: "Our efforts are not to cease because public meetings have been discontinued for a time."5

10. Church buildings should be erected for new congregations. According to E. G. White, places "should be thoroughly worked, until a humble house of worship stands as a sign, a memorial of God's Sabbath, a light amid the moral darkness."

Steps should be taken toward building a proper concept of evangelism among the laity. In Russia, some Seventh-day

\footnotetext{
${ }^{1}$ Ibid., 192.

${ }^{2}$ Ibid. , 173

${ }^{3}$ Ibid., 308 .

${ }^{4}$ Ibid. , 334

${ }^{5}$ Ibid., 337.

${ }^{6}$ Ibid. , 375.
} 
Adventists do not believe that "evangelism is a team work uniting the local church, the pastor, and the evangelist."1

Evangelism is "generally seen as the preserve of the clergy, $" 2$ and some SDA members have yet to learn that "it is a sin for the minister not to include the church in his evangelistic program." ${ }^{3}$

A comprehensive concept of evangelism is needed in Russia, in which evangelism is perceived as

a dialogue in which Christians' actions and attitudes of loving care, and righteous discipline, empowered by the Holy Spirit, awaken a non-Christian so that he will receive Christ as divine Savior and Lord of his life in the Christian fellowship and in the world."

Evangelism in Russia should not be some event that SDA churches are supposed to engage in from time to time. Samuel Moffett makes it clear that "if the church no longer believes in evangelism, it has no business being a church, for evangelism is the business of the Church." 5 The local church must become the center of evangelism.

Successful churches are marked by the availability of opportunities for members to get involved in soul winning as

${ }^{1} \mathrm{Halvorsen,} 16$

${ }^{2}$ Green, 13.

${ }^{3}$ Woolsey, 57 .

${ }^{4}$ Samuel Southard, Pastoral Evangelism (Nashville, TN: Broadman Press, 1962), 8 .

${ }^{5}$ Fowler, 29 . 
pointed out by one successful pastor:

To have an evangelistic preacher is not enough. To have brilliant sermons and great music is not enough. The only church to which people go regularly and in large numbers is one where the people attend in order to help win others to Christ. ${ }^{1}$

The recently organized Russian SDA Church has depended on public evangelism for numerical and spiritual growth. The rationale for this dependency is pointed out by Dudley and Cummings :

Churches will not grow numerically unless their members are nurtured in spiritual growth, preserved from apostasy, and incorporated as responsible members of the body of Christ who will gladly share their faith. Churches will not grow spiritually unless they have a constant supply of new converts to provide a fresh infusion of spiritual life and unless the renewed members have outlets for service. Which is more important, internal or external growth? We might as well ask the same question of breathing in or breathing out. You can't have one without the other for long. So it is with internal and external growth in the church. ${ }^{2}$

Mere external church growth does not necessarily reflect evangelism within the church. External growth can be due to transfer growth. External growth may also be due to biological growth, where young people reared in the homes of believers are led to take their stand for Christ, influenced by such factors as Sabbath Schools and educational systems. The most important source of growth in Russia is conversion growth, which is the

'Orley Berg, The work of the Pastor (Nashville, TN: Southern Publishing Association, 1966), 106-107.

${ }^{2}$ Roger L. Dudley and Das Cummings, Adventures in Church Growth (Washington, DC: Review and Herald Publishing Association, 1983), 16 . 
only growth which "will expand the kingdom of God beyond its present boundaries and measure our impact upon the world."1 Today, the Russian SDA Church believes that it will be empowered by the Holy Spirit. As Dudley and Cummings say:

Now, empowerment paradigm is a New Testament concept just waiting to be rediscovered by the church. It is the Bible's construct for successfully pursuing the dream, the mission of taking the gospel to the world. The church must relearn the biblical lesson. ${ }^{2}$

Naden sees as vital the role of the Holy spirit in evangelism: "The Holy spirit gives to the members the abilities to minister, the opportunities to minister, and the empowerment to move ahead in successful ministry." ${ }^{3}$ There is room for public evangelistic crusades in Russia, but church members must not merely be spectators.

\section{Perception of Public Evangelism in Russia}

Since the history of the SDA church in Russia has been unique, there was a need to establish whether evangelism theory can also be applied to the Russian setting.

During the 1997 Volga Vatsky Conference session I administered a questionnaire to the delegates. Statements listed were designed to measure the pastors' perceptions of public evangelism in Russia. Fifty pastors were given the

\footnotetext{
${ }^{1}$ Ibid., 18.

${ }^{2}$ Naden, 9 .

${ }^{3}$ Ibid.
} 
questionnaire. The questionnaire was administered to the group under my control. Each statement was adequately explained. Respondents were told to choose only one of the following:

True, (2) False, (3) Don't know. The results of this survey appear in table 13 .

If evangelism is to be the business of the church, there is need to change the Russian concepts about evangelism. Respondents were asked whether evangelistic crusades are a common activity in SDA churches; 54 percent agreed while 39 percent disagreed, and only 7 percent said they did not know.

of the fifty pastors who were asked, only twenty-six agreed with the statement that crusades are a common activity in SDA churches. Since this information was collected in 1997, after several years and hundreds of evangelistic crusades, the responses suggest a need to involve the local church so that they dream and think about evangelism.

More than half (59\%) agreed that local churches were capable of conducting evangelistic crusades, but 41 percent did not think so. This suggests the need for training the local churches and equipping them for evangelism. The need for training extends also to the pastors because only 57 percent agreed that Russian SDA churches were capable of conducting crusades. If evangelism is to be the main business of the church, pastors need to be empowered to carry out the job because 50 percent of the 
TABLE 13

PERCEPTION OF PUBLIC EVANGELISTIC CRUSADES

\begin{tabular}{|c|c|c|c|}
\hline \multirow[t]{3}{*}{ statements } & \multicolumn{3}{|c|}{ Responses } \\
\hline & True & False & $\begin{array}{l}\text { Don't } \\
\text { Know }\end{array}$ \\
\hline & \multicolumn{3}{|c|}{ Percentage } \\
\hline $\begin{array}{l}\text { Evangelistic crusades are a common activity } \\
\text { in SDA churches. }\end{array}$ & 54 & 39 & 7 \\
\hline $\begin{array}{l}\text { Russian SDA church pastors are qualified to } \\
\text { conduct crusades. }\end{array}$ & 57 & 20 & 23 \\
\hline $\begin{array}{l}\text { SDA church pastors from America and other } \\
\text { countries are better qualified than Russians } \\
\text { to conduct evangelistic crusades. }\end{array}$ & 36 & 24 & 40 \\
\hline $\begin{array}{l}\text { SDA church pastors are well equipped } \\
\text { technically e.g. slides, projectors, etc. }\end{array}$ & 32 & 50 & 18 \\
\hline $\begin{array}{l}\text { There is need to reorganize the conduct of } \\
\text { crusades. }\end{array}$ & 49 & 19 & 32 \\
\hline $\begin{array}{l}\text { Euro-Asia Division, Unions and Conferences } \\
\text { have special funds for evangelistic crusades. }\end{array}$ & 37 & 14 & 49 \\
\hline $\begin{array}{l}\text { Euro-Asia Division and Conferences have } \\
\text { enough money for evangelistic crusades. }\end{array}$ & 7 & 42 & 51 \\
\hline $\begin{array}{l}\text { Russia has adequate literature for conducting } \\
\text { crusades. }\end{array}$ & 49 & 33 & 28 \\
\hline $\begin{array}{l}\text { Euro-Asia Division, Unions and Conferences } \\
\text { have special budgets for evangelistic } \\
\text { crusades. }\end{array}$ & 50 & 6 & 44 \\
\hline $\begin{array}{l}\text { Local churches are capable to conduct } \\
\text { evangelistic crusades. }\end{array}$ & 59 & 14 & 27 \\
\hline $\begin{array}{l}\text { Local churches have enough funds to conduct } \\
\text { evangelistic efforts. }\end{array}$ & 4 & 79 & 23 \\
\hline
\end{tabular}

respondents perceived that SDA church pastors were not well equipped technically to conduct crusades. Out of fifty pastors only fifteen agreed that they were well equipped. 
In terms of funding, only 4 percent agreed that the local church had enough funds to conduct evangelistic efforts. These negative concepts about evangelism need to be changed to unleash evangelistic potential. There may not be a time when the church will have adequate resources for public evangelism. Evangelism does not depend on great sums of money. Paul conducted evangelism without money from Jerusalem. He asks, "What then is my reward? Just this: that in preaching the gospel I may offer it free of charge, and so not make use of my rights in preaching it" (1 Cor 9:18).

In Russia, if public evangelistic crusades are to be effective, proper organization of the crusade and thorough preparation are needed. Without thorough preparation, excitement over large numbers of baptisms will be short-lived as thousands of new converts leave through the back door.

\section{Planning for Evangelism}

Planning is the key to success in all endeavors of the church. Proper planning is required in all three phases of public evangelism identified by T. W. Wilson, who says "crusade evangelism is a 'before', 'during' and 'after' process." ${ }^{1}$ Referring to planning, R. A. Thompson emphasizes its importance when he says:

One of the areas of evangelism that will help us to hasten that day is in coordination. This means a planned program

${ }^{1}$ T. W. Wilson, "Crusade Evangelism," in Evangelism in the Twenty-First Century, ed. Thom S. Rainer (Wheaton, IL: Harold Shaw Publishers, 1989), 172. 
beginning with the office staff and reaching through all the departments of the church to every member. ${ }^{1}$

Raymond Woolsey also writes about the value of proper planning and timing.

It is this planning, timing, and organizing that characterizes a successful evangelistic effort and earns for it the term "campaign." In a large effort an evangelist may be fortunate enough to have a campaign manager who takes off his shoulders the details of organization. The beginning evangelist probably will not have this extra help. ${ }^{2}$

\section{Revival First Step}

Ellen $G$. White emphasizes the need for revival before an evangelistic crusade.

A serious and perhaps unsuspected hindrance to the success of the truth is to be found in our churches themselves. When an effort is made to present our faith to unbelievers, the members of the church too often stand back, as if they were not an interested party and let all the burden rest upon the minister. . . . In laboring where there are already some in the faith, the minister should at first seek not so much to convert unbelievers, as to train the church members for acceptable co-operation. . . . When they are prepared to sustain the minister by their prayers and labors, greater success will attend his efforts. ${ }^{3}$

Revival is the first step in preparing church members for involvement. Too often churches are led to conduct an evangelistic crusade without any revival. Most ministers just rush to organize the church for action and they advertise and

${ }^{1}$ R. A. Thompson, "Coordinated Evangelism," Ministry, September 1970,40 .

${ }^{2}$ Woolsey, 79 .

${ }^{3}$ Ellen White, Gospel Workers (Washington, DC: Review and Herald Publishing Association, 1948), 196. 
implement evangelism without taking adequate time and effort in reviving the church. Revival is an essential aspect of evangelism. Revival means many things to many people, but its essence is pointed out by Donald McGavran:

To most Christians a revival means primarily purifying and vitalizing the existing Church. For certain thoughtful historians, it is God's best means for vivifying His church and carrying out His program of justice, mercy, and world evangelization. ${ }^{1}$

McGavran spells out why revival should be emphasized. Revival is said to be accompanied by powerful emotions such as "trembling, weeping, agonizing prayer, and feelings of great joy and peace." 2 The beauty of revival is that it leads to holy living. Revival brings about "a restoration of New Testament Christianity."

Sins which a person hides as if his life depended on it are openly confessed and renounced. Evil habits of mind, and body-covetousness, hate, lust, addiction to drink, idolatry, race prejudice-which had for years enslaved men are broken. ${ }^{3}$

Finally, revival becomes the driving force behind evangelism as it leads people to proclaim the gospel. The church pastor will discover beauty in working with a revived church because revival creates a desire for soul winning among the members. MacGavran notes:

Revival implants Christ's Spirit in men and forthwith

${ }^{1}$ Donald A. McGavran, Understanding Church Growth (Grand Rapids, MI: William B. Eerdmans Publishing Company, 1980), 186.

${ }^{2}$ Ibid. , 190

${ }^{3}$ Ibid. , 191 
they, like their Master, make bringing salvation to men a chief purpose of their lives. A holy anxiety that their neighbors and loved ones share the redeeming power of the Gospel seizes the revived. ${ }^{1}$

Appropriate sermons, Bible studies, and seasons of prayer should be organized for the benefit of the church. If the evangelist is an itinerant minister, arrangements should be made with the local pastor so that he can first conduct a revival. Non-cooperation on the part of local church members is often a result of lack of revival. I had an experience in which a successful evangelist conducted an evangelist crusade, which was well attended by an audience of around 400 people. At the end of the crusade only a few were baptized and yet the audience had showed a lot of interest. It later turned out that the local church had not been prepared for this crusade. There were divisions and quarreling among the members even throughout the crusade; the church was having serious problems.

Ellen white confirms that "the Lord does not work to bring many souls into the truth, because of the church members who have never been converted." ${ }^{2}$ Isaiah called upon the people to revival.

A voice of one calling in the desert prepare the way for the Lord; make straight in the wilderness a highway for our God. Every valley shall be raised up, every mountain and hill made low, the rough ground shall become level, the rugged places plain. And the glory of the Lord will

\footnotetext{
${ }^{1}$ Ibid. , 192.

${ }^{2}$ White, Testimonies for the Church, $6: 371$.
} 
be revealed and all mankind together will see it. For the mouth of the Lord has spoken. (Isa $40 ; 3-5$, NIV)

Ellen White clearly points out that many are hindered from making a commitment to Christ because of the deplorable condition in the church.

There is a vast amount of rubbish brought forward by professed believers in Christ which blocks up the way to the cross. Notwithstanding all this, there are some who are so deeply convicted that they will come through every discouragement, and will surmount every obstacle in order to gain the truth. But had the believers in the truth purified their minds by obeying it, had they felt the importance of knowledge and of refinement of manners in Christ work, where one soul has been saved there might have been twenty. ${ }^{1}$

After the members have been revived they can now be expected to take evangelism as their only business. Pastors should attend only to the organizational aspects of evangelistic crusades after revival has taken place. Revival ensures that when new members join the church they will find members who will accept and welcome them into fellowship. Fellowship is a strong factor in reducing apostasies and backsliding. As long as members are aflame for God, new members will find adequate nurturing. Empowered by the spirit, all members will provide maximum cooperation in running the crusade.

The main objective of revival meetings should be to rouse the people from spiritual slumber. This can be done by reminding them of the needs of the hour and the imminent return of Christ. The role of prayer and the Holy spirit should be emphasized so as

${ }^{1}$ Ibid., $4: 68$. 
to empower members to move forward in faith. Revivals should seek to made it clear that every one has a role to play in the great Gospel Commission. Topics on last-day events, the gospel commission, prayer, the Holy Spirit, and the unity of the believers are appropriate for revivals.

\section{Formation of Committees}

Proper planning ensures that order prevails. Order is a biblical concept. Paul commanded the Corinthian church to be orderly: "But everything should be done in a fitting and orderly way" (1 Cor 14:10).. Ellen $G$. White called for order in evangelistic work when she wrote: "But there must be no haphazard, 1oose, cheap, manner of work done in any place." 1 She further pointed out that "success can only attend order and harmonious action."

\section{Meeting the Board}

Part of the planning process involves meetings with the church board. Although the pastor has a key role to play in evangelism, there is no way a pastor can monopolize evangelistic strategies. Dudley and Cummings found a positive relationship between active laity and church growth and from empirical evidences they concluded:

${ }^{1}$ Ellen G. White to Brethren in Norway, Letter 14, 1887, Ellen White Research Center, Spicer Memorial College, Pune, India.

${ }^{2}$ Ellen White, Patriarchs and Prophets (Mountain View, CA: Pacific Press Publishing Association, 1958), 376. 
The pastor will not be able to finish the task by himself, no matter how talented he is or how hard he labors. It's going to take all of us. It's going to take a caring church. ${ }^{1}$

Ellen White made it clear that cooperation between the pastor and the church was indispensable:

The work of God in this earth can never be finished until the men and women comprising our church membership rally to the work, and unite their efforts with those of ministers and church officers. ${ }^{2}$

Billy Graham and his successful team learned the need for local churches and their officers to participate in evangelistic campaigns. They never conduct any crusade without the invitation of the local church in that city. ${ }^{3} \mathrm{~T}$. W. Wilson points out that "the local church is not a tool for the use of the crusade; the crusade is an evangelistic tool for the local church." 4

A proper understanding of the relation between crusade and local church is necessary. Too many times the local church is approached to provide the logistics for a major evangelistic crusade. The church debates whether or not to get involved and even seeks to know what benefits it will get from the crusade. Evangelists need to realize the critical truth that is brought out by Joseph C. Aldrich, that "in the final analysis,

\footnotetext{
${ }^{1}$ Dudley and Cummings, 111 .

${ }^{2}$ White, Gospel Workers, 352 .

${ }^{3}$ Wilson, 173 .

${ }^{4}$ Ibid.
} 
the church is both message and medium, exemplifying and proclaiming the Kingdom of God."1

The church board is the right place to start. It is important for the board to be involved from the start. Although, the board may not be enthusiastic about new ideas and innovations, this problem may not exist where the pastor maintains adequate internal communication with the board members. ${ }^{2}$ The pastor should present the plan for evangelism to the church board only after he has made individual consultations with board members and solicited their ideas and opinions. A pastor who prepares for the formal board meeting will manage to gain support of board members.

Pastors are influenced by their perceptions of the church and of their own roles. These perceptions of the church affect the way they deal with the church board.

A pastor who perceives the church as a lecture hall views preaching as the key to the life of the church. Such a view of the church leads pastors to sideline the board and go to it only as a formality because, as Peter Savage ironically puts it,

The preacher is endowed with an unusual power, a power which Calvin regarded as virtually divine: the preacher was the one who spoke and acted in the very name of God. ${ }^{3}$

'Joseph C. Aldrich, Life-Style Evangelism (Portland, OR: Multnomah Press, 1981), 101.

${ }^{2}$ Lyle E. Schuller, Activating the Passive Church (Nashville, TN: Abingdon Press, 1981), 117.

${ }^{3}$ Peter Savage, The New Face of Evangelism (Downers Grove, IL: InterVarsity Press, 1976), 106. 
The disadvantage of this view of the church is that it leads the pastor to seek to occupy center stage and to do everything. Savage points out the disastrous effect of such a perception of pastor-lecturer on evangelism.

It fosters passivity in the congregation, making them more spectators and onlookers than active participants. They are continually on the receiving end and have little opportunity to give. This discourages the development of real disciples. ${ }^{1}$

Russians often have this perception of the church. It needs changing.

The church can also be perceived as a theater, where "the congregation sits expectantly." ${ }^{2}$ Pastors with such a perception view their major role as that of "the administration of sacraments." ${ }^{3}$ Savage says that this view of the church not only reduces the congregation into passivity, but it also "seriously limits the church's possibilities for evangelizing." ${ }^{4}$ Week after week the pastor encourages the members to come to church and sing and respond to his performance. After the drama is over the members go back to their homes. If the church board meets, its main agenda centers on the administration of sacraments and organization of the central drama and theater. Evangelism is then taken as an additional business.

\footnotetext{
${ }^{1}$ Ibid., 107.

${ }^{2}$ Ibid.

${ }^{3}$ Ibid.

${ }^{4}$ Ibid.
} 
Pastors may also perceive their churches as corporations. Savage describes this:

Under this model, the church is in the business of retailing religion, much as any other commodity is marketed. Its goal is to make the goods and services of religion available to the people. The whole church is program-oriented, the fulltime pastoral team functioning as corporation executives. Management principles forged on the anvil of the successful business world are easily transferred into this model. ${ }^{1}$

Pastors who take this approach may try to deal with their church board as a commercial management team. The commercial aspect of religion may be overemphasized. Issues which may dominate such a church board when discussing evangelism may include trained laity and good cash flow, as if these determine the church's productivity. All these things may be important, but the spiritual aspect of evangelism should be on center stage. The danger of such perceptions is the commercialization of evangelism and domination of the church board by the pastor as though he were the chief executive officer of a company.

If the pastor perceives the church as a social club, the church board's main concern will be to "cater exclusively to a select group in society, having little commitment to evangelism and less desire to move outside its own social group."2 The proper perception of the church is to view it as a community, as was concluded by the Lausanne Covenant which said,

\footnotetext{
${ }^{1}$ Ibid., 108.

${ }^{2}$ Ibid., 109
} 
"The Church is the community of God's people."1 If the pastor becomes aware that he is dealing with a community, then his whole approach to the church board changes. He should view the church board as a vital part of the community. Church board members are perceived as representatives of the community. The pastor will have to confide in the church board, seek approval of the church board, and cultivate confidence in the church board. A pastor who succeeds in winning the confidence of the church board will succeed in rallying the whole church behind him.

\section{Action Plan}

The crusade action plan should have its main goals or aims listed. These goals should be clearly stated, as they will become the basis for all other components of the action plan and justify all that is done. In formulating the goals, the specific mission statement of the church should be taken into consideration.

The importance of goals is brought out by Rick Warren, who said, "A purpose-driven church is committed to fulfilling all five tasks that Christ ordained for his church to accomplish."2 The goals for every church can be classified into five categories: "outreach, worship, fellowship, discipleship and

${ }^{1}$ Ibid.

${ }^{2}$ Rick Warren, The Purpose Driven Church (Grand Rapids, MI: Zondervan Publishing House, 1995), 103. 
service." ${ }^{1}$ The biblical support for each of these goals is listed below.

1. Outreach or evangelism is not only a responsibility for every Christian but a great privilege. Jesus said:

Therefore go and make disciples of all nations, baptizing them in the name of the Father and of the Son and of the Holy spirit, and teaching them to obey everything I have commanded you. And surely. I am with you always, to the end of the age. (Matt 28:19-20, NIV)

2. Worship should not be engaged in out of duty but should be an expression of our love for God. The psalmist said, "Glorify the Lord with me; let us exalt His name together" (Ps 34:3).

3. Fellowship is important to every Christian because it is not enough to believe; members should belong. Paul wrote: "Consequently, you are no longer foreigners and aliens, but fellow citizens with God's people and members of God's household" (Eph $2: 19)$.

4. Discipleship is defined by Warren as "the process of helping people become more like Christ in their thoughts, feelings, and actions." ${ }^{2}$ Paul affirmed: "We proclaim Him, admonishing and teaching everyone with all wisdom, so that we may present everyone perfect in Christ" (COI 1:28).

5. Service, according to Warren, "is demonstrating God's love to others by meeting their needs and healing their hurts in.

${ }^{1}$ Ibid., 119.
${ }^{2}$ Ibid., 106. 
the name of Jesus."i Paul wrote that the purpose of the gifts was "to prepare God's people for works of service, so that the body of Christ may be built up" (Eph $4: 12$ ).

It is not enough merely to have a list of goals. The goals should be prioritized so as to meet the needs for the church. Warren approaches the issue of goals in terms of five circles of commitment and points out that the aim of the "church is to move people from the outer circle (low commitment/maturity) to the inner circle (high commitment/maturity)."2

Before the evangelistic crusade the priority of goals will be:

1. Service: to equip the members for service and ministry.

2. Discipleship: to help members become more like Christ through revival.

3. Fellowship: to create a spirit of belongingness, cooperation, and oneness.

4. Worship: to express love for God.

5. Outreach: to help members participate in evangelism as a privilege.

During and after the evangelistic crusade the order of these goals may shift as the tasks will now be geared to move people from the outer circle to the inner circle with the community as the "starting point." ${ }^{3}$

\footnotetext{
${ }^{1}$ Ibid. , 104.

${ }^{2}$ Ibid. , 131

${ }^{3}$ Ibid.
} 
The objectives of the crusade should be specific, time bound, and quantifiable or measurable. Each of the five goals should have selected specific objectives. These will be useful in estimating the resources that will be required, as well as the time frame within which the objectives should be accomplished. Since evangelism is the total program of the church, objectives should be specific enough and should aim at all aspects of the church life, i.e., the five goals already presented. A comprehensive needs assessment or survey of the community will be helpful in developing target-specific objectives.

\section{Specific Activities (Tasks)}

After specifying the goals and objectives, the church board should list specific objectives under each objective of the action plan to be developed. For example, if one of the objectives is to prevent 90 percent of the new converts from apostatizing within a period of one year after the crusade, then specific activities need to be identified and put into the plan which will lead to 90 percent of the new converts remaining in the church one year after their baptism. This requires that all aspects of follow-up be thought through at the planning stage itself.

In Russia, many evangelistic crusades are organized and conducted without any plan for follow-up. After the baptism the evangelist simply gives a strong speech to the church pastor to take care of the new flock; yet "no one is in a better position 
to solidify new converts than those who lead them to Christ."1

It is important to specify each of the activities because only then will it be possible to precisely determine the needed resources. This part of planning takes a great deal of time, and the pastor will have to do most of the work and distribute some of it among members of the church board. However, if the church is to be successful in its mission there is no substitute for comprehensive planning.

If adequate time is spent developing the action plan, and especially specifying the activities, people who are assigned responsibilities know exactly what is expected of them and when. $A$ successful evangelistic crusade should be planned ahead of time.

\section{Time Frame (Dates)}

Aside from goals, objectives, and specific tasks, the action plan to be developed by the church board should include a time frame for each specific activity. Warren warns, "If you don't schedule your purposes on your calendar, they won't get emphasized."2 Unless there is a time line to each activity, monitoring and evaluation become difficult or impossible.

\section{Persons Responsible}

There is little use in developing a detailed plan which does not specify who is responsible for various activities. The pastor

\footnotetext{
${ }^{1}$ Naden, 10 .

${ }^{2}$ Warren, 151 .
} 
cannot be expected to take over everything. Assigning responsibilities creates wide opportunities for the whole church to utilize its gifts. Churches need to be empowered to participate in service, and this calls upon the pastor to train the laity for service. Involvement of many people in evangelistic crusades enhances the spirit of ownership of the crusade. Often laity are left to be spectators due to poor planning. Maurice A. P. Wood points out that laity have a right to demand training from their pastors.

Lay Christians have a right to demand training if their minister demands on them for further service. Lay training should be an integral part of the Church's annual program, whether or not there are plans for special outreach. ${ }^{1}$

\section{Resources and Budget}

Two more items should appear in the action plan: these are (1) resources required and (2) a budget. Initially, these columns will be blank in written plans but will be filled in by the various committees that will be assigned to manage specific tasks. Later, the action plans will be completed with input from the various committees.

\section{Steps to Follow}

The process of developing an action plan for an evangelistic crusade follows several steps. Initially; the pastor should plan to spend many sleepless nights alone developing the initial

${ }^{1}$ Maurice A. P. Wood, "Lay Training for Evangelism," in Evangelism: The Next Ten Years, ed. Sherwood Elion Wirt (Waco, TX: Word Books Publishers, 1978), 85. 
draft. This process should invoke extensive communication with church board members on a personal basis. That initial draft should include the individual input of various members at all levels. The process of developing action plans with the help of church board members can be summarized as follows:

1. Pastor makes initial drafts.

2. Pastor discusses draft with board members.

3. Church board canvasses for input of church members and committees.

4. Church board adopts plan of action.

5. Church board makes adjustments to plan.

6. Church board commits members to the plan.

7. Church board implements plan.

\section{Evangelism Committees}

Setting up committees is an effective way to get things done. If members are organized into committees, they will have the opportunity to work together and build relationships. Ellen white greatly emphasized the need for every member to have an opportunity to labor.

The secret of our success in the work of God will be found in harmonious working of our people. There must be concentrated action. Every member of the body of Christ must act his part in the cause of God, according to the ability God has given him. We must press together against obstructions and difficulties, shoulder to shoulder, heart to heart. ${ }^{1}$

\footnotetext{
${ }^{1}$ White, Testimonies for the Church, $4: 572$.
} 
Committees offer unique opportunities for members to work together "heart to heart" and "shoulder to shoulder." Ellen White does not recommend working alone even if the pastor is efficient. She wrote:

There is little that any of you can do alone. Two or more are better than one if there will be that humility that you will esteern each other better than yourselves. If any of you consider your plans and modes of labor perfect, you greatly deceive yourselves. ${ }^{1}$

Each committee should have a leader, someone to guide it. The chairperson of the committee should be carefully chosen because the success of the committee depends on that person.

One of the biggest tasks in organization is to be able to judge the value of men to be able to put the right man into the right job. Choosing the right leader for each group is critical. He must be someone who knows what to do and one who can carry out with a minimum of guidance from the over-all manager. ${ }^{2}$

Whenever a committee is appointed, it should have a proper job description and time frame. Unless a committee knows exactly what is expected of it and when, not much can be expected from it.

Several committees must be set up and put in charge of various aspects of the crusade. The whole process of evangelism is ongoing, involving before, during, and after events, making evangelism a whole-year event. Some of the essential committees are briefly described below.

\footnotetext{
${ }^{1}$ Ellen White, Life Sketches of Ellen G. White (Mountain
}

View, CA: Pacific Press Publishing Association, 1943), 303.

${ }^{2}$ Woolsey, 82 . 


\section{Finance Committee}

The evangelist should avoid putting the local pastor in a difficult situation by placing him in charge of funds without the help of a church committee. This committee should be set up a year before the crusade begins. ${ }^{1}$ E. G. White admonishes on the need for a finance committee.

God's people are not to go forward blindly in the investment of means that they have not and know not where to obtain. . . . Those who desire to build must first sit down and count the cost, to see whether they are able to carry the building to completion. Before they begin to carry out their plans, they must advise with wise counselors. ${ }^{2}$

The main task of the finance committee is to make a budget for the crusade. A credible finance committee will go a long way in reducing passivity of the members. Some of the members in the finance committee should be accounting professionals. In order for "the financial appeals, the allocation of funds, and the system of record-keeping . . [ [to] be internally consistent," ${ }^{3}$ professionalism and honesty should be the criteria in choosing the Finance Committee members. Schuller warns against the evils of having a faulty accounting system:

One of the most effective means of undermining the trust level within a congregation, of lowering morale, of increasing passivity, and of creating disharmony is to create a situation that causes members to believe they cannot trust

\footnotetext{
${ }^{1}$ Halvorsen, 12 .

${ }^{2}$ White, Evangelism, 85 .

${ }^{3}$ Schuller, 111.
} 
the financial accountability system of that parish. ${ }^{1}$

Budgeting is the first task of the finance committee. This "implies that we seek to determine, as far as possible, what an evangelistic mission, project or opportunity will cost, before it takes place." ${ }^{2}$ Clive Calver and others identified three basic benefits of budgeting:

It tells us how far our faith must stretch. It unpacks for us why our faith must stretch that far. It gives a basis for ongoing budgetary controls and amendments. It also means that one can contrast the anticipated expenditure on one item as against another. ${ }^{3}$

The evangelist or pastor should avoid the temptation of monopolizing the crusade budget by keeping it secret. Neither should he manipulate the finance committee by appointing his. own friends, as is commonly practiced. It makes no difference whether the crusade funds are donated externally or are internally raised, a budget should be drawn up and a committee asked to control it. There is much mystery and many questions asked concerning evangelistic crusade budgets in Russia, as perceived by respondents. This needs to be changed.

The main weakness of some evangelistic crusade budgets is that they overemphasize the needs during the crusade and almost totally ignore those after the crusade. There is usually a disproportionate allocation of resources and often the "after"

${ }^{1}$ Ibid.

${ }^{2}$ Calver, 45 .

${ }^{3}$ Ibid. 
processes of the follow-up phase of the crusade suffer from a serious resource shortage. This major weakness could be solved if the finance committee were able to balance the crusade and follow-up process.

Besides identifying, classifying, and tabulating all the expenses of the crusade, the finance committee should identify sources of funds. The pastor can help play a role in identifying sources of funds, but greater success will result if the finance committee is put in the forefront. Identifying the source of funds is a process with pre-requisites. It requires good rapport with possible funders and also a good project plan, which convinces the funders that the endeavor will succeed. A poor project plan will fail to attract funders. At the same time, poor public relations with the community will result in failure to secure funds. The task of building sources of funds is an ongoing process.

Some of these sources of funds include: The evangelist, the Conference, the Union, and the Division. Money may also come from local church funds, individual members, and the community.

At the onset, the finance committee should identify and list all possible sources. These should include non-SDA church agencies, as well as prominent members of the community. If a good action plan has been developed it will have several activities designed to benefit the community, which non-religious people will be happy to help sponsor. Identifying sources of 
funds involves identifying and studying the individual needs of prospective funders and asking them to sponsor a specific objective or set of objectives.

Initially, the finance committee should list all the prospective sources and assign a goal of how much to expect from each source. It is advisable to have as many sources as. possible. Committee members will help generate the sources. In deciding how much to expect from church organizations such as Unions, Conferences, and Divisions, the pastor should find out about the prevailing policies and practices: The finance committee should appoint other members of the church, either locally or elsewhere, to comprise a team of fund raisers with someone within the committee coordinating fund raising.

Secular methods of fund raisings that raise ethical issues should never be used. This includes all forms of gambling, raffles, or lotteries. The key to fund raising lies in the ability to communicate effectively with prospective sources of funds.

Development of a letterhead for use by the finance committee will be useful for prospective sponsors. All communications to church organizations and evangelists should be countersigned by the church pastor. Based on my experience in the field, all communication regarding funding should be done through the committee, with copies given to the local church pastor.

In many cases, there is lack of transparency in money matters as the evangelists channel all their communication 
regarding funding for crusades to Conferences, Unions, and Divisions. They rarely communicate directly with the church pastor, and never with the local crusade finance committee.

The current system of communication on matters of finance has caused much confusion and misunderstanding among the local pastor, local church evangelist, and Union or Conference officials. In one crusade, the evangelist asked me what had happened to thousands of dollars, which had been remitted to a particular crusade through the Union. Although I was at that time the person responsible for evangelism, I had no information as to how much had been remitted for this effort by the evangelist and had no idea what the crusade budget was. There had been no communication at all on financial matters.

In another crusade, funds were remitted by the evangelist to pay the rent for the hall for one year to allow effective followup. However, this fund never reached the finance committee and it was not aware of it. Since the local church did not have funds to hire the hall, about 90 percent of the new converts backslid. Later it was learned that the funds meant for the hall had been diverted by church officials and used for something other than rent.

The list of examples where evangelism suffered due to lack of effective communication reaching down to the local level regarding funding is endless. All this could have been avoided if there had been transparency in financial communications. In Russia, most of the problems resulting from finance will 
automatically be resolved only if copies of all communication between evangelist, pastors, and other funders are made available to the finance committee on whose shoulders the church board has placed this responsibility. Such transparency will empower members to be effective in fund raising from local sources; otherwise, they do not see the need to raise funds as they may think someone else is providing all funds. However, the pastor should always have copies of all communication to and from sponsors and the evangelist.

The job description for the finance committee is as follows: Committee Name: Evangelistic Crusade Finance Committee. Committee member:

1. Chairperson: Local Church Treasurer

2. Ex-officio: Local Church Pastor (also signatory)

3. Fund-Raising Coordinator

4. Public Relations Committee Chairperson

5. Transportation Chairperson

6. Supplies Committee Chairperson

7. Accounting Expert

The functions of the Finance Committee are the following:

1. Formulate crusade budget.

2. Open a separate bank account for the crusade.

3. Collect and deposit all funds and offerings.

4. Prepare monthly accounting statements.

5. Monitor all spending and keep records. 
6. Maintain accurate record of accounts payable or receivable.

7. Prepare comprehensive financial report at the end of crusade.

8. Issue receipts to all sponsors.

9. Communicate on all aspects of funds and budget.

10. Give church pastor copies of all communication with anyone regarding crusade funds.

\section{Prayer Groups}

It is essential to start a prayer group as it will serve as the powerhouse for the evangelistic meetings. Gesswein had a powerful concept about prayer; he wrote: "Prayer is the lifeline of New Testament evangelism, the oxygen for its Holy fire."1 Kane laments the lack of dependence on God through prayer, which is evident in churches today:

What the Christian mission needs more than anything else today is a revival of prayer. Our generation has lost its sense of dependence on God. We have more knowledge, expertise, tools, money, committees, land, and buildings than the church in any previous age. We have ecclesiastical power, economic power, and political power-everything but spiritual power. . . Human effort and ingenuity have displaced prayer. ${ }^{2}$

Poor results in evangelistic crusades, reflected by high rates of apostasy, could be changed if the church would make

${ }^{1}$ Armin R. Gesswein, "Prayer and Evangelism," in Evangelism, the Next Ten Years, ed. Sherwood Elionwirt (Waco, TX: Word Books Publishers, 1978), 93.

${ }^{2}$ Kane, 323 . 
prayer a part of evangelism. Dominic Bernardino says that "evangelization and prayer share a very special affinity." ${ }^{1} \mathrm{He}$ clearly bring out the role of prayer in evangelization:

Prayer enables us to see with the Father's eyes the dignity inherent within each and every person created in God's image. In prayer we can feel with the Father's heart the painful separation of his wayward sons and daughters. ${ }^{2}$

Schuller advises that the church should be organized and divided into prayer bands. ${ }^{3}$ The threefold purpose for their prayers, as pointed out by J. Oswald Sanders, is the following.

First that rapport may speedily be established and hostility or indifference be broken down. Next, that the soil of the heart may be prepared for the sowing of the seed. . . Lastly, that the soul may be liberated from the power of Satan. ${ }^{4}$

Commitment to prayer, coupled with a proper understanding of its power, calls for proper organization of prayer groups. R. A. Anderson advises that, besides special prayers in the homes of church members, "there should be many prayer groups organized." 5 The role of prayer is to be felt at all stages of evangelistic crusades: before, during, and after. Therefore, prayer groups

${ }^{1}$ Dominic Bernardino, "Prayer--The Missing Element in Evangelization," in Evangelizing Adults, ed. Glenn C. Smith (Wheaton, IL: Tyndale House Publishers, 1985), 325.

${ }^{2}$ Ibid. , 326.

${ }^{3}$ Schuller, 24 .

${ }^{4} \mathrm{~J}$. Oswald Sanders, Effective Evangelism (Grand Rapids, MI: Christian Focus Publications, 1982), 46-47.

${ }^{5}$ R. A. Anderson, 105 . 
should start soon after the committees have been organized. Before the crusade starts, prayers are required in order to overcome organizational obstacles and prepare the territory. Prayer has a critical role to play among the members themselves, as it is the only way to bring about a revival in the church. The Bible is clear about the role of prayer within church members who are focusing on missions: "But those who hope in the Lord will renew their strength. They will soar on wings like eagles; they will run and not grow weary, they will walk and not be faint" (Isa 40:31).

I have had several experiences in which prayer played a major role during evangelistic crusades. In one city, the crusade was poorly attended at first. Few people came on the opening night, and those who were managing the hall, which they had hired, advised us to close the meeting as they were going to lose money. I prayed earnestly. On the second day, around eighty people came, but from the third day up to the end of the crusade, the hall was full. Prayer can invite people to come to the crusade.

On another occasion, my assistant and I prayed after we had failed to secure a swimming pool to conduct a baptism. With only two days left before the baptism, and all efforts having failed, we pleaded with God and revisited one place where permission had been refused. Empowered by prayer, a breakthrough was made and, within a few minutes, the decision not to grant the swimming pool was 
reversed. The one responsible for the swimming pool even pointed out that she would rather risk her job to obey God so that people could be baptized. Nothing is impossible with prayer. Even the problem of apostasies can be stopped through prayer.

I found that 90 percent of the respondents said that the evangelist must have a prayer group. This shows that the church members and pastors are aware of the power of prayer and identify it as a critical component of successful crusades.

\section{Secretarial Team}

Every pastor should ensure that the church appoints a secretarial team to maintain records during an evangelistic campaign. Success in any organization requires ability to keep records through a central file system. In most of the evangelistic crusades, no meaningful information is available regarding the thousands of interested people who attended the meetings. After the crusade is over, one will hardly be able to trace the list of interests. What information is available is often incomplete and very disorganized.

Woolsey notes the kind of information required during evangelistic efforts:

The most important type of information to be handled during a campaign is that regarding perspective interests. This information should include: who the prospects are, where they live, the degree of interest they manifest, and the progress they are making in accepting the doctrines of present truth. ${ }^{1}$

\footnotetext{
${ }^{2}$ Woolsey, 89 .
} 
The responsibilities of the secretarial committee should include the following:

1. Open a file for each name received.

2. Prepare special personalized letters to be sent out to interests.

3. Update the interest files during the meetings.

4. Decide on and secure all required stationery.

5. Arrange filing system so as to assist visitation committee.

6. Maintain records of baptismal classes.

7. Prepare statistical report every month and at end of the crusade.

The task of maintaining systematically filed updated records is not easy. Evangelists should not underestimate this great task and all the support that needs to be given to the secretarial team. This simple task of maintaining records, if carefully implemented, will communicate to the new converts and interests that they are greatly loved in the church.

\section{Usher Committee}

Appointment of an usher committee during a crusade is as critical as that of any other committee. In evangelism, no task can be said to be less important than another. The greeting that visitors receive at the door as they come to the meetings may help them become more receptive to the gospel. A cheerful smile 
given by a spirit-filled usher may communicate God's love even more powerfully than the preacher's sermon. It is important for visitors to feel that they are welcome and special. The tasks of the ushers include the following:

1. Usher people to their seats after a warm greeting, accompanied by a contagious smile.

2. Ensure order and cleanliness before the meeting begins.

3. Communicate with crowds so as to minimize confusion and clear up misunderstandings.

4. Maintain order and decorum in the hall.

5. Promptly collect offerings and deposit them as instructed.

6. Maintain courtesy even when the crowd is rough.

7. Ensure that all entrances are clear.

Ushers are in the forefront and need to communicate the warmth offered by the church. They can act as a magnet to attract many people to Christ.

\section{Public Relations Committee}

Appointment of a public relations committee is one of the greatest needs for public crusades in Russia. Often in evangelistic crusades no one is assigned to seek ways to develop rapport with the community. Sometimes, the evangelist takes time to visit a few key offices before the crusade starts and seeks to build bridges. Many times the success of the evangelist or church pastor is limited. A public relations committee can 
accomplish far more than the evangelist and church pastor can do single-handedly.

Six or more months before the crusade, this committee should be set up and should implement a well-developed public relations strategy for the church. By the time the crusade is conducted, people within the community should already be aware of the existence of the Seventh-day Adventist Church and what it stands for. Some of the tasks of the Public Relations Committee are Iisted below:

1. Identify target groups and individuals for building public relations.

2. Identify objectives and activities within the action plan which can create positive publicity.

3. Develop and print a publicity brochure for distribution and mailing within the community.

4. Ensure that announcements are placed within bulletins of the churches participating in the crusade.

5. Promote "entry programs," such as stop-smoking clinics through radio, television, and newspapers.

6. Take responsibility for planning and implementing advertising strategies for the crusade.

The problem with the way publicity is currently carried out in Russian SDA churches today is that the local church has very little to do with public relations before, during, or after the crusade. This is unfortunate, as it results in the new converts 
identifying more with the evangelist than with the local church. While it is important for the evangelist to create rapport with key community leaders, this should not be a substitute for the work of the local church. What is needed today is for "crusade evangelism to serve the church rather than the church serving the crusade."1 If local churches through their public relations committee can reach the heart of the local community, they will have succeeded in creating a vital link within their community. This link will prove to be a foundation for cementing relations between new converts and the local church.

\section{Transportation Committee}

A transportation committee is always needed throughout the crusade but is critical for taking the candidates to the baptism site. Before the crusade begins, the transportation committee can make arrangements with the managers of the public transportation system and secure additional buses to run during the critical hours of each night, just before the meetings begin and at the end of the evening meetings. The committee should make careful study of the needs of various sectors of the community, as far as transport is concerned. If additional buses (or some other form of transport) are made available, the schedules and timetables should be printed and distributed.

In most evangelistic crusades, provision of transport service

\footnotetext{
${ }^{1}$ T. W. Wilson, 173 .
} 
for carrying candidates to the baptismai site is problematic. The transportation committee can work out the details and have alternative plans. It is not uncommon for sealed contracts with the transportation corporation to be broken at the last minute due to the influence of opposition by the Orthodox Church.

\section{Supplies/Materials Committee}

This committee is to be in charge of securing, keeping, and distributing all materials to be given out during the crusade. These include Bibles, songbooks, tracts, books, pencils, and ribbons. The evangelist will give the guidelines as to how and when the materials should be given out. This committee should devise a system of distributing materials in an orderly manner. I have noted that in most crusades there is no appropriate system of handing out supplies.

\section{Visitation Committee}

It is hard to think of a successful evangelistic campaign without the backing of a church-appointed visitation committee because visitation is a critical component of successful evangelistic crusades. In most evangelistic crusades the requests for visitation are far more than what the evangelist can handle. The whole church needs to be involved in a systematic program of visitation. This requires the zoning of the territory and assignment of each street to members of the church. Visitation is a before, during, and after process. Most 
evangelistic crusades do not have any visitation programs after the crusade. This is a terrible mistake, which contributes to high rates of apostasy.

\section{Music Committee}

The music during evangelistic crusades should be coordinated by a church-appointed music committee. Warren realized the role of music: "A song can often. touch people in a way that a sermon can't. Music can bypass intellectual barriers and take the message straight to the heart."1

It is important for the music committee to know a few basics about music so as to make their work easier, yet the committee should not try "to appeal to everyone's musical preference and taste. ${ }^{2}$

Music is a divisive issue that separates generations, regions of the country, personality types, and even family members. . . You're wasting your time if you're searching for a style of music that everyone in your church will agree on. ${ }^{3}$

Warren gives some important rules in selecting a music style because "music sets the mood of service."4

1. Consider the Iyrics and the tune when previewing all the music to be used.

2. Speed up the tempo so that the music can have

\footnotetext{
${ }^{1}$ Warren, 279.

${ }^{2}$ Ibid., 280.

${ }^{3}$ Ibid., 380.

${ }^{4}$ Ibid., 286.
} 
both spiritual and emotional impact on the audience.

3. Update the lyrics by translating or rewording some of the biblical metaphors and theological terms to make them more understandable to unbelievers.

4. Every true revival has always been accompanied by new music, as indicated in Ps 96:1: "Sing to the Lord a new song; sing to the Lord, all the earth." Therefore, encourage members to write new songs.

5. Where possible, use the latest musical technology because, as Warren puts it, "we invite the unchurched to come and sit on seventeenth-century chairs (which we call pews), sing eighteenth-century songs (which we call hymns), and listen to a nineteenth-century instrument (a pipe organ)."

6. While unbelievers should not be forced to sing, it is a mistake to remove all congregational singing from a seeker service. ${ }^{1}$ Evangelists should realize that most Russian SDAs are conservative in their music and there is a need for maintaining proper balance. Warren's rules in selecting evangelistic music are.not fully applicable in all situations. However, trends indicate a change in music tastes that will make warren's rules applicable within the next few years.

Merrill L. Enright advises that a fifteen-minute song service should be conducted before the preacher takes over. This should be introduced by prayer and should emphasize congrega-

\footnotetext{
${ }^{1}$ Ibid., $286-291$
} 
tional singing.' This is applicable to Russia today because of its culture, which has a special place for music.

The great Reformer Luther said of music:

Next to theology I give to music the high place of honor. It is a discipline and a mistress of good order and good manners. She makes the people milder and gentler, more moral and more reasonable. ${ }^{2}$

With reference to congregational music, Ellen white wrote, "The melody of song, poured forth from many hearts in clear, distinct utterances is one of God's instrumentalities in the work of saving souls." ${ }^{3}$ She further wrote: "The melody of praise is the atmosphere of heaven, and when heaven comes in touch with earth, there is music and song." 4

Ellen White does not oppose instrumental music and stresses good singing.

Music can be a great power for good; yet we do not make the most of this branch of worship. The singing is generally done from impulse or to meet special cases, and at other times those who sing are left to blunder along, and the music loses its proper effect upon the minds of those present. Music should have beauty, pathos, and power. Let the novice be lifted in songs of praise and devotion. Call to your aid, if practicable, instrumental music, and let the glorious harmony ascent to God an acceptable offering. ${ }^{5}$

${ }^{1}$ Merrill L. Enright, "Music in the Evangelistic Worship Service," Ministry, January 1955, 38-39.

${ }^{2}$ Ibid. , 38 .

${ }^{3}$ White, Testimonies, $5: 493$.

${ }^{4}$ Ellen G. White, Education (Nashville, TN: Southern Publishing Association, 1923), 161.

${ }^{5}$ White, Gospel Workers, 325. 
Certainly her advice is applicable in Russia. The music committee, starting about six months before the crusade, should work within the guidelines given above and prepare the following items for the meeting:

1. Select the crusade songs and print the song books.

2. Audition all special music before presentation.

3. Consult the speaker for hymns to be included.

4. Select appropriate instruments.

5. Arrange for choirs to present special songs.

6. Start a crusade mass choir.

In most evangelistic crusades in Russia, I noted that congregational music is rarely used and the audience is not given any song books. I found that 70 percent of the respondents identified the need for the evangelist to "have good musicians." It is therefore important for the music committee to make thorough preparations.

\section{Food Committee}

It is good to appoint a food committee that will prepare food for the evangelistic team. Often a rather high proportion of the crusade budget goes into good catering provided by commercial enterprises. A food committee made up of local members can do the job quite well, following a prescribed menu. This will result in great savings. The food committee should have professional nutritional consultants. 
I experienced a crusade where poor planning and a lack of hygiene in food preparation resulted in the evangelist getting sick. A food committee appointed several months before the crusade should explore all matters regarding food and come up with excellent meals in consultation with the evangelist.

\section{Equipment Committee}

A committee should be appointed to oversee the equipment used during the crusade. This committee should have a technician as chairperson, someone who knows the technical aspects of light and sound. This committee. will be responsible for ensuring that there is enough light in the hall so that people are able to read their Bibles without straining their eyes. Adequate lights should also be provided in the halls and doorways, so that greeters and ushers can carry out their jobs effectively.

The sound system should be tested and from time to time committee members should advise the sound controller regarding pitch, balance, and volume of the loudspeakers. Proper microphones should be used. Operation of projectors, tape recorders, and all other visual and audio equipment should be tested prior to the meeting.

One of the main tasks of this committee should be to ensure that every sermon is recorded and copies are duplicated and made available to the bookstand committee for sale to members of the audience. After the end of each sermon all the equipment should be 
collected and secured. All lights should be turned off. The committee should have a thorough knowledge of the electrical design of the hall, including main switches and fuses. Members of this committee are the first to arrive at the hall every day, at least an hour before the meeting, in order to set up everything and consult with the evangelist regarding the program for that night.

\section{Committee for the Handicapped}

Appointment of a committee for the handicapped will ensure that the needs of handicapped people are met. The world, including some evangelists, behaves as though handicapped persons are not human beings at all. C. G. Cross warned against the church neglecting those who do not see well in its evangelistic crusades.

Could you stand where I am for a while, you would see that the church has done very little to evangelize these millions of blind and visually handicapped people, almost an entire continent of them. As a denomination we wouldn't think of operating anything short of a worldwide evangelistic program. ${ }^{1}$

The need for a committee to oversee the needs of handicapped people is obvious, especially for Russian crusades. Even the National Television caters to the needs of the deaf during news bulletins. A specialist in sign language is always there together with the news reader to translate the news for the deaf. This is a challenge to the church because in many cities there are many handicapped people whose spiritual needs are

${ }^{1}$ C. G. Cross, "Our Missionary Program for the Blind and Visually Handicapped," Ministry, July 1964, 4-5. 
ignored as though they do not exist.

I had the opportunity to attend one evangelistic crusade in which divine providence led to special arrangements being made for a group of deaf who attended the meetings. The crusade was conducted in a hall owned by an institution that catered to the deaf mutes. The evangelist had initially not intended to target this group. However, since their hall was being used, these deaf people decided to attend. Arrangements were made for a sign language translator and about thirty deaf mutes were baptized from follow-up after this short crusade and a lay member was assigned to lead the group. A unique choir of deaf mutes was started and they rendered special music using sign language-praising God in sign language with accompaniment of instruments and a trio that sang out the words of the song for the audience.

Invalids may need special places when they come to the meetings. Those who are hard of hearing may need to be in the front or near the speaker. Blind people may need to sit in convenient places. Visually handicapped people who can use Braille will need to have Braille books of the Bible, as well as Braille literature. They may need to be registered with the Christian Record Braille Foundation, so that they can receive materials regularly and can order a variety of things to help them in their newfound faith.

Unless a special committee is set up to study their 
community and identify the needs regarding handicapped people, this group will always be sidelined.

\section{Telephone Evangelism Committee}

A committee should be appointed to implement a telephone evangelism program. In Russia there are tremendous opportunities for using the telephone to reach out to the masses in crisis situations. One month before the crusade, a tele-counseling service should be started. This service should be organized by a small committee comprising the pastor and a few mature people who can give counsel to those who phone for advice. Several volunteers may need to be involved throughout the day to respond to those seeking advice or asking questions.

Everyone who calls should be invited to come to the crusade and benefit from the meetings. The crusade is highlighted as the best place to have one's questions answered and emphasis should be on the benefits of coming to the crusade. This telecounseling service is publicized through the invitations given out to the public. The announcement should include an invitation to phone questions to the number given.

I had experience in one crusade where this service was advertised and offered by a female lay member who used her phone for this purpose. She received many calls daily and gave simple advice and invited all those who phoned to come to the meetings. This was a very fruitful service. 


\section{Security Committee}

The appointment of a hall security committee will take pressure off the pastor or evangelist. A lot of work goes into the identification, negotiation for, and preparation of a hall for a public evangelistic crusade. In many cases the task involves negotiation with several people, not just one person. Sometimes permission to use a particular hall is granted but later withdrawn. At times negotiations need to be made with other groups who may have booked the hall so that they can reschedule their activities. If the pastor tries to do this by himself, he will have no time left for anything else, and at the end he will feel frustrated and burned out. Negotiating for a hall should start one year before a crusade.

The chairperson of the hall security committee should distribute responsibilities to the committee members right from the start of negotiating for the crusade hall. Their other tasks should be to divide the hall into sections and assign leaders for each section to ensure that those who try to disrupt the meetings are dealt with. It is the responsibility of this committee to establish links with the local police and update them on the type of security they would like and when they would like police present. Maintenance of order both inside and outside the hall is a critical function of the committee. The hall administrator should be the chairperson of this committee. 


\section{Platform Committee}

Overseeing the daily program during the crusade requires the services of a platform committee. This committee should be responsible for the arrangement of the platform. The daily order of service is prepared by this committee, which should work hand in hand with the music director and the equipment committee responsible for audio-visuals. The arrangements of flowers, potted plants, and the pulpit is all done by this committee. The major role of this committee is to see that the program runs according to schedule. Time management is a major task of this committee.

\section{Bookstand Committee}

The bookstand committee is responsible for erecting a stall for Adventist literature sales. The books should be sold in a convenient location, away from the main entrance to the hall so as not to distract people who move in and out of the hall. The chairperson of this committee should be a colporteur, who will be able to make contact with prospective buyers as well as suppliers of literature. All books, Bibles, health food items, cassettes, and videos offered for sale during the crusade should be sold only through the bookstand. Special prices should be offered for the books sold and no non-Adventist literature or other materials should be sold from the bookstand without committee approval.

\section{Children's Ministries Committee}

A children's ministries committee should be appointed for 
each crusade. In Russian public evangelistic crusades as much as 30 to 40 percent of the audience is made up of children. In most of the crusades no efforts are made to meet the needs of this age group. The problem lies in that no provision for children is made at the planning stage. Selecting a children's ministries committee can help solve this problem.

Gifts suitable for children must be ordered and used in public crusades. Those who give out the gifts should never ignore a child or reject them just because they are young. The committee should ensure that children are fairly treated during the crusade.

The committee should also design a special programs for Sabbath School at the church to which children will be invited. Baptismal classes for children should be started and conducted by persons prepared to deal with children. Each child who is a baptismal candidate should feel special and should be personally reassured of God's love.

Children twelve years and above who choose to be baptized should be given special encouragement to help them prepare to become strong members of the church. The children's ministries committee should arrange for personal interviews with every child who is a baptismal candidate and also arrange a time to talk with their parents.

It is a mistake to ignore the needs of children, as Lionell Hunt aptly points out:

I have frequently revisited places and found those who 
years ago were converted as children grown up to be men and women; and, what is more, I have found them earnest Christians and ready to testify that when "those children's meetings were held" in their town or city, they experienced the forgiveness of their sins and a change of heart, and then began to live the new life which is by the faith of the Son of God. ${ }^{1}$

\section{Health Committee}

A health committee will go a long way towards making health the right hand of the gospel. The combination of health and public evangelism is always recommended in Russian evangelistic campaigns. This committee will plan health talks and special health programs before, during, and after the crusade. Arrangements should also be made to render first aid to anyone who should require it at the meetings. During the crusade local doctors may be engaged to offer consultations to charity patients. This activity could be coordinated by the medical committee.

Ellen White wrote on the role of medical evangelism in the last days: "I wish to tell you that soon there will be no work done in ministerial lines but medical missionary work."2

Clifford Anderson observed that "everyone is interested in health today" and that "people everywhere are anxious to learn how to preserve their health." ${ }^{3}$ It is the duty of this committee

\section{${ }^{1}$ Lionell A. Hunt, Mass Child Evangelism (Chicago: Moody} Press, 1951), 20-21.

${ }^{2}$ Ellen G. White, Counsels on Health (Washington, DC: Review and Herald Publishing Association, 1946), 533.

${ }^{3} \mathrm{Clifford} \mathrm{R}$. Anderson, "Let's Capitalize on Health," Ministry, June 1995, 19. 
to develop strategies related to health and health evangelism and oversee their implementation.

\section{Baptism Committee}

often committees are appointed to oversee all other aspects of the public evangelistic crusade except the baptism. It is essential that a baptism committee be set up. This committee carries several responsibilities:

1. Organization of baptismal classes.

2. Individual interviews with baptismal candidates

3. Personal visits with baptismal candidates

4. Preparation of baptismal gowns

5. Preparation of baptismal place and facilities for changing clothes

6. Identification of an appropriate site with adequate, clean water for the baptism

7. Collection of all essential information on each candidate

8. Registration of each baptism candidate for follow-up

9. Maintain time management during the baptism ceremony

10. Ensure that all candidates have a helper and companion to assist them and reassure them of God's love and acceptance into the church.

\section{Family Enrichment Committee}

This committee will emphasize family values. The Russian community still has strong family values, and most people who 
attend the meetings value their families. This committee should identify appropriate topics and resource persons for presentations before, during, and after the crusade by organizing special programs aimed at family enrichment.

I had an experience in Russia where one foreign evangelist who desired to emphasize family enrichment came with a family specialist as one of his team members. This specialist was given time to address the audience on family issues. His presentations left the audience greatly disappointed because most of what he emphasized was culturally far removed from Russian culture. If this specialist had consulted with the local family enrichment committee, he could have been able to meet the needs of the audience.

A family life committee can also prove very helpful because if family life issues are included in the crusade program, the authorities will not hesitate to grant permission for conducting the crusade.

\section{Community Survey Committee}

A church-appointed community survey committee will carry out a needs assessment of the community. Without conducting a survey we are in danger of "offering the public what we think they need, rather than what they need."1

The Community Survey Committee should include social

\footnotetext{
${ }^{1}$ Dudley and Cummings, 79.
} 
scientists such as sociologists, psychologists, economists, and anthropologists. Some of the roles of this committee will include:

1. Carry out a demographic survey of the community.

2. Advise those assigned as hall administrators on how to group the people according to interest groups such as teachers or musicians.

3. Advise the crusade manager on appropriate group-bonding activities.

4. Advise the church on appropriate entry events or programs to be implemented in preparing the territory.

5. Develop a profile of the worldview of the target audience so that the messages presented can help the people make needed changes.

\section{Crusade Coordinating Committee}

Every evangelistic crusade must have a crusade coordinating committee made up of the chairpersons of all the committees and chaired by the crusade manager, evangelist, or local pastor. All the committees will report to the crusade manager when the crusade starts.

The crusade coordinating committee must meet every day at an appropriate time, either in the morning or in the evening after the meeting. On a daily basis the crusade should be evaluated by members who should give feedback on the progress of the meetings. Reports should point out strengths and weaknesses as well as 
obstacles encountered. Suggestions should be given on appropriate action plans to be adopted and changes in strategies.

The evangelist must attend this daily briefing. At this time he needs to give words of encouragement to the team. A season of prayer, when people plead with God for guidance and direction, should always be a part of this committee meeting.

If the crusade is large, the crusade manager must have one or more assistants who will help ensure that everything goes according to schedule.

\section{Follow-up Committee}

It is important to appoint a follow-up committee that will make action plans for successful follow-up. Hunt noted that the lack of follow-up is characteristic of most efforts: "Herein lies the weakness of many evangelistic efforts, mainly because the difficulties of following up converts are too great."1

The need for follow-up is brought out clearly by warren, who observed that "incorporation of new members into the church fellowship does not happen automatically." If a follow-up emphasis is lacking, the result is often a high rate of apostasy:

If you don't have a system and structure to assimilate and keep the people you reach, they won't stay with your church. You will have as many people going out the back door of your church as are coming in the front door. ${ }^{2}$

Warren also identified five unspoken questions which should

${ }^{1}$ Hunt, 122 .

${ }^{2}$ Warren, 310 . 
guide the follow-up committee in carrying out its responsibilities. These are questions people ask before they make a commitment to join a church:

1. People ask about acceptance. Establishing small affinity groups helps to allow people with similar age, interests, problems, or backgrounds to fellowship with each other.

2. People ask about Eriendship. This need can be met by creating opportunities to develop relationships through activities such as weekend sports activities (as tried by Monte Sahlin). ${ }^{1}$ Gottfried Oosterwal says that 57 percent of adults who join the Adventist Church list friends and relatives as the most important influence in their decisions. ${ }^{2}$

3. People ask if they are valued and whether they are needed. The creation of opportunities for people to express their gifts, talents, and abilities is essential to answer this need.

4. People ask what are the benefits of being a member of the church. This can be answered by explaining biblical, practical, and personal reasons.

5. People ask what are the expectations and requirements of members. This can be answered by explaining clearly the benefits and responsibilities of membership.

The follow-up committee should design a system which answers 1993,8 .

${ }^{1}$ Monte Sahlin, "Friendship Evangelism," Ministry, September

${ }^{2}$ Ibid. 
all the basic questions. Failure to do so will result in higher rates of apostasy. Currently, crusades in Russia are conducted without any follow-up committee to address these issues. The result is neglect of the new converts and other interested persons, resulting in many of the new members leaving through the back door of the church.

Faced by high rates of backsliding, Borge Schantz wonders whether the system of reporting baptisms should not be changed so that they are reported one year after they have occurred. Thus only those who are still in the church will be taken into consideration.

The situation can be turned around if an evangelist empowers the local follow-up committee to keep every new member.

\section{Entry Events}

Many entry events can be implemented to meet the felt needs of the target population. Entry events are defined as "those programs or services through which non-members first participate in a church-sponsored activity." ${ }^{2}$ Dudley and Cummings give ideas on several entry events:

Since health concerns rate high for many people, some churches have planned entry events such as five day plans to stop smoking, alcohol and/or drug abuse seminars, cooking and nutrition schools, weight control clinics, stress management seminars, and vegetarian restaurants. Other events may focus on family issues. Examples are pre-marriage forums, marriage enrichment seminars, workshops on community skills and

\footnotetext{
${ }^{1}$ Borge Schantz, "A Western Massage in Eastern Europe," Ministry, November 1993, 8.

${ }^{2}$ Dudley and Cummings, 87.
} 
conflict management, parenting skills, working mothers' seminars and managing family finances. ${ }^{1}$

Some of the entry events appropriate for Russia are listed below:
1. Health evangelism
2. Service evangelism
3. Literature evangelism
4. Voice of Prophecy courses
5. Agriculture workshops.

\section{Advertising}

Advertising is the key to success in almost any activity, including public evangelism. The need for advertising is brought out by George Barna: "And yet, I believe that developing a marketing orientation is precisely what the church needs to do if we are to make a difference in the spiritual health of this nation for the remainder of this century." ${ }^{2}$

Advertising or marketing just before the crusade has several tangible advantages brought out clearly by Barna. ${ }^{3}$ These advantages are equally applicable when preparing to conduct an evangelistic crusade in Russia.

1. Advertising or marketing results in numerical growth as

${ }^{1}$ Ibid., $87-88$.

${ }^{2}$ George Barna, Marketing the Church (Colorado Springs, Co: Navpress, 1993), 12 .

${ }^{3}$ Ibid. , 34-36. 
it leads to devising of intelligent plans.

2. Marketing calls upon planned approaches which enhance the efficiency and effectiveness of one's communications.

3. Marketing calls for the specification of one's goals and objectives as well as action plans that lead to greater understanding of ministry.

4. Marketing leads to maximization of scarce resources.

5. Marketing leads the church to be more sensitive to the needs of the community.

6. Marketing leads the church to develop more extensive community outreach opportunities.

7. Marketing leads to enhancement of personal ministries among laity and greater assumption of responsibility.

8. Marketing leads to identifying and training of a new team of leaders.

9. Marketing creates a new environment in the church leading to church revival and renewal.

Several methods can be used to advertise public evangelistic crusades in Russia. These include newspapers, radio, television, invitations, posters, and billboards. Each of these methods is presented below.

\section{Television Advertising}

The use of television is effective in reaching certain classes of the society which are otherwise difficult to reach. 
However, if television is used, prime time, from 7 to 11 a.m. and 6 to $11 \mathrm{p.m.}$, is the best time to advertise, as many people sit to watch their favorite program. If the church decides to advertise through television, it is often best to engage the services of a reputable marketing agency specializing in television advertising. The technique of gaining the attention of television viewers is very complicated, since Iisteners practice selective listening and viewing. At the same time care should be taken not to overdo and produce a technically and professionally perfect television spot with questionable ethics. Great care needs to be taken and the expense should be justifiable. All of this may require a comprehensive survey of the target groups.

\section{Radio Advertising}

Radio is another strategy that may be used to advertise in Russia. Care needs to be taken in selecting the radio station to be used. This decision should depend on target groups. Popularity of programs should be taken into consideration. Some radio program are popular among young people, others are popular among women, and so on. Radios also have prime time and choices will have to be made on timing, frequency, and content of the announcement. All announcements should arouse enough curiosity for people to have a desire to attend.

There are many advantages for the use of television: "Sight, 
sound, motion, attention and wide reach." On the other hand, radio "offers wide reach, segmented audiences and is inexpensive." ${ }^{1}$ All the messages, either by radio or television, should arouse curiosity among the listeners. Of utmost importance is that the crusade should fulfill promises made during advertising.

\section{Personal Invitations}

Most of the advertising for evangelistic crusades is done by door-to-door personal invitations given by church members. The following principles will help guide pastors in the use of handbills to advertise their meetings:

1. Print the invitations on good quality paper.

2. Use four-color printing.

3. Use a standard size; don't make the invitations too small.

4. Hire a professional for layout and design.

5. Do not clutter the invitation with too much information.

6. Include answers to the questions What? When? Where? Who? How much? Also give starting date, speaker, and how to get to the hall.

Many ways can be used to distribute invitations. Each method has its own merits and demerits. It is better to use all methods available for the distribution of invitations.

${ }^{1} E$. Jerome MCCartby and William D. Perreault, Basic Marketing (Boston: Irwin, 1990), 429. 
Posters

Another method of advertising the evangelistic crusade is the use of posters. A few basic principles are listed for consideration when using posters:

1. Make the message clear; you want to encourage attendance.

2. Use four colors to attract attention.

3. Use posters that are large enough to be easily seen.

4. Place posters in prominent places.

5. Put up posters just before large numbers of people pass where they are posted. Replace posters that are taken down or damaged.

\section{Newspapers}

Another way of advertising through the printed page involves the use of newspapers. The advantages and disadvantages of using newspapers for marketing are summed up by McCartby and Perreault. Among the list of advantages are "flexibility, timeliness, local market, credibility"; the advantages are "expensiveness, short Iife," and inability to "be passed along."

The major factor which should be considered is the size of circulation. Obviously the wider the circulation, the wider the publicity of the crusade. The evangelist should compare circulation figures before deciding which newspaper to use.

The advertisement should be designed professionally.

\footnotetext{
${ }^{1}$ Ibid., 429.
} 
Newspaper advertising is not just a matter of putting words together. A little error in a newspaper advertisement, such as one letter or figure missing or a spelling error, is enough to distort the whole message of the communication. It pays to consult an advertising agency so that the message is properly designed.

Use of color in newspaper advertising increases the chance of readers' noticing the advertisement. Budget constraints should be considered when deciding on use of color.

\section{Billboards}

Use of billboards is yet another way of advertising evangelistic crusades in Russia. Big billboards in full color, placed at strategic places, can effectively communicate about crusades. Where possible, such billboards should have neon lights so that at night people will be attracted to the message.

I analyzed some of the reasons why so much has gone wrong with advertising before crusades. It has become clear that in many cases the pastor's motives were right, but the methods were wrong. Pastors and Conferences sometimes diverted budgeted, advertising funds so that the savings could be used for some other pressing need. I am aware of one pastor who economized on the advertising budget and other precrusade expenses and used the funds to buy a car that was extensively used during the crusade. It was also extensively used for follow-up and resulted in great savings in the crusade transportation budget. Several similar 
cases can be cited. A faithful pastor's wife could not understand why so much money could be "wasted" printing invitations when the Lord had given her the talent and ability to type fast. She asked, "Why not type and save the funds for other pressing needs?"

Through such approaches and attitudes, which say "the end justifies the means," evangelistic funds have been diverted from the advertising budget to some other "good" cause. Such mistakes could be avoided if pastors and church administrators could learn the basic value of marketing. A lack of appreciation for the value of marketing in an evangelistic crusade was the basic reason why most of the pastors at Carter's crusade in Nizhny Novgorod in 1992 failed to understand why 30 percent of the crusade budget was "wasted" by advertising.

\section{Conducting the Crusade}

After all the preparation is completed, the time comes for conducting the actual crusade. By this time an air of expectancy should prevail among the church members and the community at large. A few guidelines are given to help make evangelistic crusades in Russia more successful.

\section{Evaluation Seminar with Leaders}

The first task of the evangelist should be to meet with the various committees which have worked to prepare for the crusade. Each one of these committees will give a report of the work that 
has been done. A special two-day seminar over the weekend should be organized for this event. It is essential for the evangelist to put aside time to listen to the reports so that he becomes aware of what has been done and what still needs to be done. Several corrections may still need to be made at this late hour. The other main objective of this seminar is to seek to work out differences which may have arisen between members of the crusade team. This seminar should be a time to forgive and forget and to resolve to work together as members of one team. It should also be a time for the team to plead with God for an outpouring of the Holy spirit.

\section{Rapport with Local Community}

There is need for the evangelist to establish rapport with all levels of the community, including the church members. It makes a difference if an evangelist preaches to the local church first to empower them for the great work they are about to take on. More than that, the evangelist should never forget to thank faithful members who will have toiled hard to prepare for the crusade. Even though it is their responsibility to prepare for the crusade, still the evangelist should express gratitude and encourage them to finish the work they have started.

Most members hold the traditional view that the work of the laity in a crusade ends at the beginning of the crusade. As soon as the evangelist comes, he should make it his task to change this view. The laity should be told about their critical 
role during and after the crusade.

The other major reason for the evangelist to come early for the crusade is the need for establishing rapport with local leaders at all levels. The evangelist needs to visit the local leaders and also hold press conferences to announce his arrival through the public media. Such meetings with local leaders should be well planned so that they offer another occasion to advertise the meetings. An evangelist should always extend personal invitations to community leaders and take time to give these leaders a broader view of the work of the SDA Church worldwide. Each leader visited should be given appropriate literature and a Bible as a gift from the SDA Church. The local church pastor should accompany the evangelist and be introduced as the local representative of the SDA Church.

\section{Opening Night}

The evangelist should come early so that the final details of the opening night can be worked out. Risks should be assessed and precautionary measures planned so that any eventuality can have an immediate solution.

\section{Rehearsal}

A complete rehearsal of the opening night's program is necessary because of the confusion which can prevail.

All those with assigned roles should take part in the rehearsal of the first night's meeting. Participants should know 
exactly what their positions are and what they are to do. When visitors come the first night, they should be impressed by the order and organization. Even if too many people turn up for the opening night, it should become evident that such an eventuality was anticipated and provisions made.

\section{Inaugural Program}

The highlight of the opening night of the crusade should be the inaugural program. A simple program should be arranged in which a high-profile community or national leader is invited to give a brief speech which highlights the work of the SDA Church at the local, national, and international levels. It should become evident from the inaugural speech that the visitors have not come to witness a sect but a worldwide movement.

If properly planned, an inaugural speech can accomplish great things for the crusade. The involvement of a high-profile leader will earn wide publicity for the crusade at no cost. The press should be alerted to the inaugural visit. Special invitations should be given to key leaders and reporters to attend the program. The following morning, news about the visitor and his speech will appear in the media. Summaries of the visitor's speech will also highlight the work of the SDA Church.

often it is easy for evangelists to control the contents of the inaugural speech. This is done by writing the initial draft 
of the speech and submitting it to the speaker, together with copies of statistical data or a book about the worldwide work of the Seventh-day Adventist Church. Although a few changes may be made to the speech, usually the secretary of the leader will not change it too much.

Finally, adequate arrangements should be made so that the evangelist can give gifts to the guest. The gift should always include SDA literature and a Bible, as well as a certificate of appreciation. This same occasion can also be used to give a gift to some other prominent leaders who may have accompanied the guest. Most of the responsibility for conducting an inaugural program will be carried by the public relations committee.

\section{Inconveniences of First Night}

It may not always be possible to anticipate all the inconveniences of the first night: Room should be made to accommodate many surprises. The evangelist, as well as the rest of the team, should remain calm and patient and maintain team work. Decisions should be made quickly and communicated efficiently to all those taking part so that confusion is minimized. All committee chairpersons should be asked to remain alert so that changes in program can be communicated and new instructions given rapidly.

\section{Short and Powerful Sermon}

The preliminaries of the first night may overcrowd the 
program and other delays may be caused by unanticipated changes. Therefore, the evangelist should prepare a short but powerful sermon for the first night.

\section{Evaluation}

All committee chairpersons and assistant leaders should be on the move during the first night to see that everything goes according to plan. Immediately after the meeting all those participating as greeters, ushers, or members of other committees should assemble for a brief meeting in which a few observations are made and corrections suggested.

\section{Daily Crusade Program}

The daily program during the crusade is very important. Nearly three quarters of those surveyed $(72 \%)$ said that an "evangelist's ability to organize a good program" was a critical factor in the success of a crusade. The crusade manager should be instructed in the importance of time management, and specified times must be adhered to strictly. Programs should be started on time regardless of the size of the audience. A lively pre-program song service should be planned. Public managers should not overcrowd the program with so many preliminary activities as to leave only a short time for the actual sermon. All preliminary activities should be given a specified time with no allowance for running over. The platform manager should not hesitate to cut short a program if it infringes on the preacher's time. 
Special programs should be planned and announced to attract an audience. Crusade managers should ensure that no two special programs are scheduled for the same day. Adequate variety should be provided so that the varying needs of the audience can be met. Once in a while, special guests should be invited and announced. Crowds are very interested in seeking help in such areas as,

1. Health: medical counseling and five-day stop-smoking programs

2. Family enrichment: communication, spouse abuse, divorce

3. Child training: sibling rivalry, adolescent behavior, delinquency

4. Diet and nutrition

5. Premarital counseling.

Guest artists, such as musical groups and instrumentalists, should be invited to perform. The crusade should be arranged in such a way that it meets the spiritual, physical, social, and mental needs of the audience. Each day should bring some surprises.

Some evangelists want to be formal during crusades, and may want to have several people seated on the platform, much like happens at church on Sabbath morning. The program must be simple without too many formalities. Adequate exposure should be given to the church pastors for the new churches which will be established, as well as to the local church pastor and assistant evangelist who will continue with the meetings. These people 
should play leading roles in the crusade to create a good

foundation for follow-up. The sermon should not be too long and the program should end on time.

\section{Monitoring and Evaluation}

During the course of the crusade a daily meeting of crusade staff should be conducted in which progress can be monitored and evaluated. The main focus of the meeting should be to seek ways to make the crusade more fruitful, especially long-term. In Russia, these briefing meetings were generally not utilized to discuss future action plans and strategies to improve the followup. It is important for the evangelist to daily secure input regarding follow-up plans. Failure to finalize these plans can result in confusion towards the end of the crusade.

The daily evaluation meetings should also be used for prayer focused on the crusade. The mistake in many crusades is that often there is no separate prayer group which is organized, leaving the crusade committee as prayer group. This is not the best plan as it does not highlight the importance of prayer in a crusade. Furthermore, lack of separate prayer groups overloads the crusade committee.

The best time for the crusade committee to meet is in the morning hours, perhaps early, with breakfast together. By having a working breakfast, committee members will have adequate time to interact and share their perceptions, which will in turn be 
brought to the notice of the organizers.

All committee chairpersons or their representatives must be asked to meet. The evangelist, together with his assistants, should also attend. A schedule should be prepared and distributed so that members of the committee can make it part of their program.

\section{Visitation during the Crusade}

A proper visitation system should be developed by the evangelist and his team to ensure that the people who ask for a visit are visited. Members of the visitation team should be taught how to pray for the ones they visit and how to spend only a few minutes when visiting people at their workplace.

\section{Length of the Crusade}

Three to four weeks is not enough for a major evangelistic crusade which will yield long-term results. Three to four weeks is adequate time to introduce the people to Jesus, but not enough to establish people in the truth. The evangelist must plan for at least two to three months ( 8 to 12 weeks, meeting at least three nights per week), especially in Russia where people have had no Bible for at least sixty or seventy years. Of the respondents, 38 percent indicated that the short duration of the crusades was one of the factors contributing to the high percentage of backsliding. If the evangelist cannot stay the ideal length of time, he should still budget for eight to twelve weeks and have an assistant evangelist finish the crusade. 


\section{During the Crusade}

Several auxiliary services should be a part of the evangelistic crusade. One of the most important of these services is to have a bookstand where members of the audience can buy Bibles, other literature, audio cassettes of the sermons, and Christian music. The bookstand should be properly manned and the stock replenished regularly. Special discounts should be given to those attending the meetings.

Another service which should be made available involves the evangelist and his assistants making themselves available to the audience after the evening sermon. Most evangelists make a mistake of rushing to their hotel rooms soon after the sermon. Evangelists should come into the main hall and mix freely with the people and communicate with them. Usually there are those who want special prayer from the evangelist, so the evangelist and his assistants should pray for them and lay their hands on the people who seek healing from Christ. Meeting, talking, and praying with members of the audience individually is very important.

Another service which can be given during the crusade is free medical consultation by doctors. Some of the people who come to the crusade will greatly appreciate the availability of free medical service.

In each crusade, arrangements should be made to conduct a Bible correspondence course concurrently with the crusade. The audience should be encouraged to enroll, and lessons should be 
distributed by group leaders. The objective is that by the end of the crusade many people will have completed the lessons to receive their gifts and certificates.

\section{Attendance Incentives}

In many evangelistic crusades conducted in Russia, various incentives are given, such as books and Bibles, in order to encourage attendance and participation. This aspect of the crusade is conducted in a haphazard manner in most crusades. Often the way these incentives are distributed destroys the spirit of reverence and worship. It is important to have a supplies and materials committee which will work out all the details regarding distribution of incentives.

The evangelist should decide on which books he wants to give and at which stage. All these incentives should be clearly identified and if possible these should be indicated on the attendance card. The audience will be motivated if they know exactly what they may get and under what conditions. Alternatively the names of the books may not be indicated, but the card should be designed with a hole to punch after each book is issued and also after the Bible has been issued. Such a simple change in the attendance card will solve misunderstandings between those assigned to distribute the incentives and the members of the audience. After each incentive is given, the card will be punched or signed in the appropriate space. 


\section{Preparation for Baptism}

The baptismal committee plays a key role in the preparation of candidates for baptism. The evangelist, church pastor, assistants, and new pastors should work together to prepare people for baptism. Soon after the altar call is made and new converts are registered in the baptismal classes, the instruction should be arranged. Evangelists should avoid forming large classes. The interests of the baptismal candidates should be considered when establishing groups. Some grouping criteria must be used such as age, interest, and location.

In most evangelistic crusades the baptismal candidates are poorly prepared due to several constraints which range from shortage of time to inadequacy of space for classes to meet, and shortage of baptismal class teachers. Proper planning before and during the course of the crusade will be helpful in identifying the obstacles and developing an appropriate action plan.

The key to strong Bible classes for baptismal candidates is that the evangelist "should support it and build it up with his strong influence, as only the evangelist can do."1 On a daily basis the evangelist should meet with all the baptismal class teachers. They, in turn, should "keep the evangelist informed of the special needs of baptismal candidates." ${ }^{2}$ In many

${ }^{1}$ Louise C. Kleuser, The Bible Instructor (Washington, DC: Review and Herald Publishing Association, 1949), 65.

${ }^{2}$ Ibid. , 66. 
evangelistic crusades this time is critical.

Much interest can be lost by not taking care of it at the appropriate time. The devil knows who is about to make a decision, and he stays very close to that individual. The Bible instructor too should stay very close. Watch whether each particular one is at the meetings or whether he is absent. Some will tell you when they are having battles to fight, others will not tell you, and you must sense their need and get close to their hearts. ${ }^{1}$

Most Russian public evangelistic crusades have resulted in

mass conversions where thousands of people register for baptismal

class. Such huge responses cause administrative challenges. It is difficult to organize 3000 or more people into small groups for effective baptismal preparation. The evangelist can hardly gain a personal knowledge of more than 3000 people over a short period of time or even half a year. The logistics required to deal with thousands of baptismal candidates are impossible. Some baptismal candidates do not know exactly what they are being baptized for.

\section{Timing of Baptismal Classes}

Whatever the administrative problems faced, "methods of evangelism which tend to hurry people into church membership, giving little opportunity before baptism to prove themselves, are most certainly to be decried." ${ }^{2}$ The evangelist needs to create time to prepare the candidates before baptism. This must be part of the initial plan for the crusade. The altar call for baptism should come a week before the end of the crusade. Soon after the classes

\footnotetext{
${ }^{1}$ Ibid.

${ }^{2}$ R. A. Anderson, 259.
} 
are established, the evangelist must share his time with the pastors responsible for each section of the hall who should take thirty to forty minutes every day to prepare people for baptism. The evangelist should realize that as much as his sermons are important, the work of preparing the baptismal candidates is also very important. The available time must be shared and all preliminary activities must be cut off. The crusade committee, working hand in hand with the baptismal committee, should decide the best time to have these classes. The meeting can start with the pastors meeting their baptismal candidates in their sections first, followed by the evangelist's sermon, or the order may be reversed.

The technique of asking the baptismal candidates to come early for classes does not work very well in Russia due to several factors. In the first place, some of the baptismal candidates will not be able to report early either due to transportation bottlenecks, delay in being released from their workplace, the long distance which they travel every day, or the timing of the local transportation network. Second, some candidates may not be able to come early due to factors such as unwillingness to travel alone or parental restrictions on children traveling alone. These same factors may pose an obstacle if the evangelist tries to have the baptismal classes after the end of the normal time of the crusade. The evangelist should make the Bible classes a major part of the crusade. 


\section{Decentralization of Class Organization}

The registration of baptismal candidates should be simplified and decentralized. Special cards should be available to each section pastor. These should be given to those who are registering for baptism to be filled out and returned to the pastor.

During the coverage of Bible doctrines by various pastors within their sections, another technique can be used. Pastors can encourage all candidates to complete their Bible lesson course. This is another way to effectively cover doctrines. Every evening during the time the pastors are teaching baptismal classes, the evangelist should visit the various sections, covering at least two to three sections every night. Within the fifteen to twenty minutes available to him for each group, the evangelist must give instructions to candidates and again call for those undecided to make up their minds and register for baptism. Above all, the evangelist must pray for each group. The group approach to preparation of baptismal candidates provides opportunities for the evangelist to find out some of the problems faced by candidates and allows him to help identify suitable solutions to the problems. This gives the evangelist a part in the preparation of baptismal candidates. By dealing with smaller groups, the evangelist will have a greater impact on the people than if he deals with the whole audience. The main emphasis in preparing baptismal candidates is brought out by Rex D. Edwards: 
As a church we proclaim that through personal faith in the Lord Jesus Christ a person is born again through the Holy spirit. Baptism is the dramatic picture of the believer's faith and participation in the death and resurrection of Christ (Romans 6:4-5) .?

\section{Use of Incentives for Baptisms}

Misunderstanding of baptism is sometimes reflected by those who seek baptism for the sake of incentives. Some evangelists announce to the candidates that all those who will be baptized will receive special Bibles signed by the evangelist. Such an announcement may motivate some people to register for the sake of the Bible. In some Russian crusades, hundreds of people were reported baptized, but the figure included some people who were baptized more than once under different names, either at the same baptism or at separate baptismal services.

In one outstanding case a crusade manager heard the wife of a baptismal candidate persuading her husband to rejoin the baptismal queue and be baptized again, as she wanted a second Bible. The husband was refusing to rejoin because the water was very cold. The wife kept pestering the husband to be rebaptized so that he could get another Bible until the husband joined the queue. The crusade manager alerted the officiating pastor and when this candidate's turn came, the officiating pastor refused to baptize him. The candidate simply left this pastor, joined another queue, and was baptized by another pastor just for the sake of the Bible.

${ }^{1}$ Rex D. Edwards, "Baptism and Conversion," Ministry, August 
If the evangelist plans to give Bibles to those being baptized, he should take care with how this is done. Since most of the baptisms are conducted during the course of the crusade, it is better to have the section pastors distribute the Bibles during the baptismal class.

\section{Follow-Up}

Gary W. Kuhne defines follow-up as the "spiritual work of grounding a new believer in the faith" ${ }^{1}$ Abraham $J$. Jules defines the follow-up stage as the post-evangelism

stage during which the back door is effectively closed.

It is the phase when bonding, nurture, and grounding take place through spiritual guardianship and mentorship. This last critical phase should be seen as an ongoing process in which church members shepherd their new believing friends. ${ }^{2}$

Once the members have been baptized they should be organized into what Warren called "purpose-based teams." He identified five purpose-based teams: mission team, music team, membership team for fellowship, maturity team for discipleship, and ministry team for service. ${ }^{3}$

All evangelists are aware of the problem of new converts who leave through the back door after evangelistic crusades. The follow-up committee should submit its suggestions and recommendations on a plan of action for follow-up. This plan can serve as

\footnotetext{
${ }^{1}$ Kuhne, 112 .

${ }^{2}$ Jules, 15 .

${ }^{3}$ Warren, 148 .
} 
the basis for the final action plan which will be adopted by the evangelist, his team, and especially the new church pastors.

The challenges of follow-up are enlarged by the fact that often new churches are formed with little financial help and few human resources. A successful follow-up requires the support of active laity who will join hands with the newly appointed pastors. Even if the new church is established with a membership of only two hundred new members, it will take a hard-working pastor a very long time to visit all these members. By the time he makes his first round some of the members may have already lost interest. In order to solve this problem, the following is suggested.

\section{Establish Peer Visitation Program}

Before the meeting comes to an end the pastor should capitalize on the interest groups and help their members exchange information about themselves. A program to communicate with each other by visiting each other, telephoning each other, and writing encouraging letters to each other should be tried. Each new member should be asked to communicate with at least five other members at least three times each week for two months.

\section{Appoint Selected Laity as}

Pastor's Assistants

Before the crusade begins outstanding lay members who are not employed, either due to retirement or failure to secure a job, should be selected and asked to be part of the crusade team. 
These laypersons should work together with the evangelistic team on a daily basis. By the end of the crusade these lay members can help with the follow-up work, assisting the new pastors in shepherding and discipling the new members.

The expenses of these lay members should be worked into the main budget of the crusade. Their expenses should involve accommodation, food, and transportation. Adequate transportation money should be provided so that their visitation will not be limited. For the time they work with the pastor they should be given a monthly stipend.

It is the duty of the evangelist to clarify the duties these laypersons are expected to perform and what is expected of them. Coaching should be provided to help them carry out their work. I talked to some African pastors who have successfully used this concept in major evangelistic crusades and with good results. With the shortage of pastors in Russia, coupled with budget constraints, this idea can successfully be used in Russia.

\section{Continue Regular Meetings with Whole Groups}

One of the techniques to effectively follow up mass conversions in Russia is for the new pastors, or local pastors or an assistant evangelist, to continue regular meetings at an agreed frequency such as twice or three times a week, with one of the meetings purposefully scheduled in the new church or churches on Sabbath. 
The assistant evangelist should adequately prepare for the follow-up meetings. This is the time to cover the great prophetic messages, for converts "will never forget the spiritual lessons they learn in the first few months after conversion."1 It is essential for the new believers to be encouraged to attend weekly Sabbath worship services. The Orthodox Church has placed an emphasis on ceremonies so it is not rare to find many Russians who attend church only twice or thrice a year, and yet still describe themselves as strong Christians. There is danger that this same attitude may be in the minds of the new converts.

In dealing with new believers the new pastors are counseled to:

organize times of fellowship and recreation such as meals, birthday parties (each one bringing some food), or outings. Take the opportunity to present the newest Christians to the others. Help the church members to get to know each other better. ${ }^{2}$

\section{Organize Cottage Meetings}

Based on interest groups, the new converts should be organized into small groups according to their geographical residential areas. These cottage meetings should focus on prayer and fellowship. The advantages of meeting in homes are clear and should be considered by the new pastor:

${ }^{1}$ S. D. Ponraj, Church Planting Guide (Lalgarh, Madhupur, Bihar: Mission Educational Books, 1995), 84.

${ }^{2}$ Ibid. , 87. 
It is easier for new leaders to lead a smaller group.

It is not necessary to rent or buy a building. They

foster good relationships between the believers. They allow for more personal pastoral care. ${ }^{1}$

\section{Organize Youth Ministries}

The Asia-Pacific Division conducted a survey to find out why 39 percent of its youth left the church every year. The findings are applicable to Russia too. A typical comment of youth was: Orphans in the church? That's what we are. We are nobody's children. The church does not even know we exist. Why call us the leaders of tomorrow when the church is not interested in us today? ${ }^{2}$

An effective follow-up program is required in Russia after each crusade so that the youth will not feel as orphans in their church. Anywhere between 20 and 40 percent of the audience coming to evangelistic crusades in Russia are youth. After bap-tisms are conducted, a sizeable proportion of the new converts are youth. Most pastors in Russia lack the skills to structure a follow-up program which meets the needs of youth. The evangeljst should arrange for the Conference Youth Director to counsel to the pastor of the new church regarding youth ministry. During the course of the crusade the new pastor should be guided step by step to start youth ministries. By the end of the crusade a core youth ministry group should be in place with meetings planned for every Sabbath. The key to success in youth ministry lies in the nature of

${ }^{1}$ Ibid., 93.

${ }^{2} \mathrm{G}$. T. Ng, "Adventist Youth in Asia-Pacific: Orphans in the Church," Youth Ministry 5, no. 122, 1995, 25. 
planned activities. This is why it is essential that before the evangelist leaves he should make sure that a definite action plan has been developed. The programs planned should keep a balance between the "spiritual, intellectual, social, and physical realm. . . And these programs may be the reason that students keep coming back for Bible study." ${ }^{1}$

Activities are very important in youth groups and this is emphasized by Borth Wick:

What gives identity and cohesion to most youth groups is the weekly or monthly activities, which build group comradery and foster positive peer acceptance. . . . For parachurch organizations and church groups alike, these meetings and activities build fellowship, foster outreach, and provide Christian, fun activities that give students alternatives to the drunken parties of some of their school friends. ${ }^{2}$

Lawrence Richards gives advice in structuring youth ministry and points out essential elements:

But successful youth ministry isn't built on program or gimmicks. Successful youth ministry requires involvement of youth and adults in the . . . ministry, and the development of programs that facilitate involvement in these processes. ${ }^{3}$

If properly planned, the activities will include fellowship, worship, outreach, and evangelism. Basic training of youth leaders through workshops or seminars should be provided and

${ }^{1}$ Paul Borth Wick, Organizing Your Youth Ministry (Grand Rapids, MI: Zondervan Publishing House, 1988), 125.

${ }^{2}$ Ibid., 125

${ }^{3}$ Lawrence O. Richards, Youth Ministry (Grand Rapids, MI: Zondervan Publishing House, 1972), 329. 
planned with the Conference or Union youth director being asked to conduct the training.

\section{Church Planting}

The next task of the evangelist after the baptism is the planting of churches. This is another area where many evangelists in Russia have faltered. Often thousands of newly baptized members are "dumped" into one church in which they get nothing but stunted growth. There is no way an evangelist can expect that one thousand or more new members can be organized together to create a vibrant church. In deciding on the question of how many churches to plant, the evangelist should never ignore the principles and dynamics of small groups.

It is not practical for an evangelist to expect one pastor to meet the needs of several hundred new church members. Evangelists should not expect the impossible. I asked one pastor why he had not followed up the thousands of people who had been baptized into his church, and had then disappeared. The pastor told him that it was just impossible for me to effectively care for more than one thousand newly baptized converts. "Impossible!" he repeated, and I agree. Any pastor who tries to do the task by himself will fail. At the same time when planting a church there is need to create opportunities for the new members to be actively involved. This is pointed out by Dudley and Cummings:

Members actively sharing their faith and leading others to the Lord are not nearly as likely to become discouraged and 
drop out. But research has revealed that unless the congregation gives a person a role in the church, a task to perform, or a group to join, within one year he or she will likely become inactive. ${ }^{1}$

It is advisable for the evangelist to obtain a commitment that the conference will assign a new pastor for the newly appointed church even before the crusade is started. In one crusade, I was told that I would get a new pastor from the Conference and he waited in the place for several weeks. Finally an eighteen-year-old youth was sent by the Conference as the new pastor for the newly established church. After a few weeks the youth took leave to visit his mother and stayed for one month. By the time he came back the interests had disappeared.

In yet another case a pastor was promised by the Conference; he came and started the crusade and stayed to the end. At the end, the elderly layperson who had been newly appointed as pastor refused to stay behind and do follow-up work as he did not like the city. The newly established church remained with no pastor for several weeks and the new pastor who came had to start afresh since most of the newly baptized members had disappeared.

\section{Church Building}

The evangelist must make sure that a church is built before the task of evangelism is considered accomplished. E. G. White was quite clear about the need to build a church for newly established congregations: "Whenever a company of believers is

\footnotetext{
${ }^{1}$ Dudley and Cummings, 11 .
} 
raised up, a house of worship should be built. Let not the workers leave the place without accomplishing this."

The critical need for a church building is pointed out by White, who went to the extent of saying that "in some cases it may be better to hire some money than not to build." ${ }^{2}$ A major factor in the high rates of backsliding could be the lack of a church building. White even suggested that the lack of a church building had an effect on the number of people who decide for the church: "Had there been a pleasant and commodious house of worship there, more than double the number that were really gained would have taken their stand for the truth."

In Russia, the need for a church is critical because of the cultural context. The Russian Orthodox Church is known for its massive church buildings which are a source of historical pride to the nation. A place of worship is a must, or else society views the group as dissidents or sects unable to put up a church building. New converts will be made fun of because they lack a church building. Many in the community will say words of discouragement, such as those pointed out by White: "These people have no church, and you have no place of worship. You are a small company, poor and unlearned."

\footnotetext{
${ }^{1}$ White, Testimonies for the Church, $6: 100$.

${ }^{2}$ Ibid. , $6: 601$.

${ }^{3}$ Ibid., $6: 101$

${ }^{4}$ Ibid.
} 
The evangelist should, however, take into consideration the economic conditions prevailing in Russia today. Churches are essential, but the new members will not be able to build a church on their own. At the same time all levels of the SDA Church organization face a serious resource shortage. There is no money to build new churches and the growth of the existing churches requires additions. New congregations are starting up so often that it simply is not possible to think of building adequate churches for every new congregation. Alternative possibilities should be explored, such as hiring secular halls for Sabbath meetings or establishing home churches. The focus of the evangelist should be less on church building and more towards what Rick Warren calls "the purpose-driven church," which "shifts the focus away from church building programs to emphasizing a people building process." ${ }^{1}$ Warren observes that "if you will concentrate on building people God will build the church."2

\section{Establishing a Purpose-Driven Church}

Evangelists should make sure that the new churches they establish are purpose driven because plans, programs, and personalities do not last. But God's purposes will last. A personality-driven church is one whose success will depend on the driving personality of the pastor of the church.

\footnotetext{
${ }^{1}$ Warren, 10 .

${ }^{2}$ Ibid., 81.
} 
Evangelists should not envision a program-driven church which emphasizes so many church programs and creates so many positions just for people to do something. Instead of maintaining old programs without being creative they should look for alternatives. Pastors who are left to meet the needs of the newly established churches should be trained to do all they can to ensure that the programs in the church serve a purpose. Tradition should not be allowed to be the driving force behind newly established churches. Creativity and involvement of the church members in creating a sense of purpose and mission for the whole church are essential. Even the Sabbath services should be lively. Ellen white writes about the need for good services and clearly advises against long sermons and dull services:

The preaching at our Sabbath meetings should generally be short. Opportunity should be given for those who love God to express their gratitude and adoration. . . . Every one should feel that he has a part to act in making the sabbath meetings interesting. ${ }^{1}$

Pastors need to avoid monotonous sermons and this can be done by including items such as testimonies and poems. Long, boring sermons overload the new members and may contribute to backsliding. Services should resemble worship in the heavenly sanctuary, which white describes.

There they will assemble in the sanctuary from Sabbath to Sabbath, from one new moon to another, to unite in loftiest

\footnotetext{
${ }^{1}$ White, Testimonies for the Church, 6:361-362.
} 
strains of song, in praise and thanksgiving to Him who sits upon the throne and to the Lamb forever and ever. ${ }^{1}$

One of the techniques which can be used to make the services more interesting is the use of songs. A service should include congregational singing, special songs, prayer, and opportunities for testimonies.

Several program can be implemented by the church to entiance the purpose and mission of the church which has just been established. Opportunities may involve several of the following, which should be organized according to interests:

1. Ministries for children: Adventist Youth Clubs, Pathfinders, Voice of Youth

2. Temperance and health: temperance contests, drug-abuse program

3. Music: choirs, conducting, instrumental and singing groups

4. Outreach programs: hospital visitation, prison programs, house-to-house visitation, Bible study, lay crusades

5. Literature evangelism: colporteur work.

Rick Warren advises that specialized groups should be started within the church. Warren classifies these groups into four: "seeker groups, support groups, service groups and growth groups."

Those who join seeker groups are those who get involved in evangelism or outreach programs. Support groups are involved in

\footnotetext{
${ }^{1}$ Ibid. , 368.

${ }^{2}$ Warren, 146.
} 
missions of mercy; their objective is to provide "congregational care, fellowship and worship." ${ }^{1}$ The new converts who join service groups are specifically assigned to "a common task, project, or ministry."2 Growth "groups are dedicated to nurturing, discipleship training, and in-depth Bible study." ${ }^{3}$ The pastor assigned to take care of members of the new church should be careful not to force any of these new members into any group. People should be allowed to "choose the type of small group that best fits their needs, their interests, their stage of life or their spiritual maturity." ${ }^{4}$

The evangelist should not assume that the new pastor possesses all the skills required of him. The Zaokski Adventist Seminary started only recently and the majority of pastors have limited exposure to the professional aspects of ministry. It is the evangelist's duty to spend much time with the newly appointed pastor or pastors and share basic ideas regarding the needs of the new church and the strategies which they should adopt. The new pastor should also be introduced to the concept of follow-up. The follow-up plan should be worked out with the involvement of the new pastors who will be responsible for the new converts. The new pastor should be allowed to have his own input into the

\footnotetext{
${ }^{1}$ Ibid.

${ }^{2}$ Ibid.

${ }^{3}$ Ibid.

${ }^{4}$ Ibid., 147
} 
plans. Russian pastors may have less knowledge of pastoral theories, but they are rich with life experiences, for they have been to the school of experience and they know God and have a deep love for Him. They will complete the gospel work in Russia. Their role in public evangelism cannot be underestimated.

\section{Cultural Aspects of Evangelism}

Various cultural matters should be considered during evangelistic crusades in Russia. These cultural aspects will have a great bearing on the long-term effect of the crusade. There are especially important for foreign evangelists.

\section{Prayer Posture}

In Russian culture, posture in prayer is important. During the crusade only two postures are acceptable: kneeling and standing. Sitting postures, common to Western churches, are not acceptable. If the evangelist wants to pray, he should always ask the audience to stand or kneel for the prayer. The audience is usually overcrowded and it is often not possible to kneel during crusades.

It is important for evangelists to understand the Russian culture on this point so that the audience will be more open and accepting of the new teachings. These cultural factors should not only be followed in the hall, but in all interactions with the audience or members of the audience, as well as at the SDA church. Some evangelists, when counseling or visiting, have 
offered prayers while sitting. This is unacceptable in Russia. Even when praying for food on the table, the evangelist must remember to stand for prayer.

\section{Criticism of Orthodox Church}

Within the crusade sermons, the evangelist should show respect for the Russian culture. Some evangelists preach in Russia as though they were agents of other world powers seeking to expand their culture by painting the Russian National Church as an agent of the devil. Evangelists should understand that, unlike anywhere else in the world, Communism persecuted not only Protestant churches, such as the Adventist Church, but also the Russian Orthodox Church. All churches met the same fate. Thousands of Russian Orthodox Church priests died for their faith as did SDA pastors and members. The Russian nation was nurtured by the Orthodox Church and E. G. White's counsel should be taken seriously: "The truth should be presented with divine tact, gentleness and tenderness." ${ }^{1}$ Criticism of the Orthodox Church and its practices can easily be misinterpreted by the audience. Foreign evangelists should avoid giving the idea of expansionism. Some Protestant Churches that are recording faster growth rates than the SDA Church in Russia do not criticize the Russian culture openly by attacking the orthodox Church. People in Russia are looking for meaning in life; they are looking for God. The

\footnotetext{
${ }^{1}$ White, Testimonies for the Church, $6: 400$.
} 
evangelist's major agenda should be to lift up Christ. That alone is enough to draw the masses. At a later stage new members can be assisted to understand more about prophecy and the Orthodox Church.

\section{Wearing of the Cross}

Evangelists should avoid taking controversial stands regarding the wearing of the cross. Evangelists in Russia will notice that most Russians wear the cross and value it highly. Wearing the cross is cultural in Russia and evangelists may misunderstand this. Respect for cultural diversity should be shown by evangelists. For example, Westerners value the wedding ring, which symbolizes certain cultural values; the Indians value the marriage necklace which is also a symbol. In the same way, the Russian Christian finds it difficult to think of a Christian life without the cross. It is a symbol with certain cultural values. Some wear a cross on a chain while others make the sign of the cross after prayer. Evangelists should be sensitive to such cultural factors. In one meeting I was conducting, an Orthodox priest visited the crusade and announced that he was going to excommunicate all members who would continue visiting the crusade. His main criticism was that the SDA Church did not emphasize the cross and he gave many examples to support his argument. I ignored the priest's remarks and at the end of the meeting he prayed and said, "Amen." Further, I made a sign of the cross after his prayer and that simple event dispelled the priest's doubts. More people attended the meetings, 
and at the end of the crusade one of the deaconesses of the Orthodox Church was among those baptized. Then she explained that she did not need the cross anymore, for she had understood that Christ was now living in her heart.

\section{Special Gowns for Pastors}

The preacher should identify as closely as possible with the culture of the people he is serving. In Russia, the evangelist should have a special gown for preaching. Culturally the Russians expect the preacher "priest" to be in a special gown. Use of the gown increases acceptance by the audience.

\section{Respect Religious Celebrations}

Some evangelists have painted some common religious celebrations as sinful or inferior. At a crusade which was conducted during the Christmas season, the evangelist used the occasion to spoil the people's Christmas mood by mocking Christmas as a pagan institution. Evangelists should avoid purposefully hurting people's feelings by condemning harmless cultural practices in a public gathering.

In Russia there are several celebrations of religious significance, including Christmas and Easter. These celebrations have great meaning for many people. One can imagine what the audience will think about an evangelist who uses a critical approach against these religious events. Alternatively, the evangelist should take advantage of such opportunities to make 
these celebrations more meaningful. Celebrations can be used by the evangelist with good effect on the audience. The case of one foreign evangelist who visited Russia during Easter celebrations demonstrated the power of taking advantage of cultural celebrations in sermons. Culturally, during Easter, the common greeting among people in Russia is "Christ is risen." The evangelist stood and his first words were "Christ is risen." He was not fully prepared for the audience response: They broke into a powerful chorus of "He is risen." He followed his greeting by a sermon on the risen Savior.

The Touring Evangelist

On some occasions visiting evangelists have spent considerable time and expense touring Russia. It is not the touring that is a problem but rather the way it is done and the impression that is created. Evangelists need to be careful not to erode their influence upon the people they minister to. Russians have a. culturally defined perception of a minister of the gospel. Any activity such as touring, which creates a perception of a pleasureloving pastor, should be entered into with great care. Touring schedules should never interfere with the crusade schedule. Travel is expensive in Russia, especially air travel. Members may fail to understand how and why the evangelist can spend so much money on touring. It is better if such travel can be done quietly, either before or after the crusade. 
Evangelist and Translator Relationship

There have been several incidents in which decisions of the evangelists seemed to have been influenced by their translators. Translators are rarely pastors, but they play a key role in accomplishing the task of the foreign evangelist. Often the evangelist depends on the translator more than on the local pastor as most pastors may not speak the evangelist's language. Translators can work out their own agenda by taking advantage of the communication gap between pastor and evangelist.

In several cases the translator has influenced the decisions of the evangelist. In one such case the evangelist, under the influence of the translator, insisted on appointing someone as a new pastor for a newly established church. When the local Conference officials (who knew better) tried to suggest an alternative, the evangelist refused and threatened to withhold funding support for the follow-up work. Finally the Conference gave in to the evangelist's wish; one year later the new pastor broke away from the church and took with him a section of the church to start his own movement. Evangelists should make all efforts to secure support from the local church pastor, and communication should be established between the evangelist and the local pastor.

Appreciation of Hospitality

There are cases when evangelists depend either on the services 
of the local pastor's wife or other local helpers. In such cases the evangelist should remember to express his gratitude as best as he is abie to. Pastors' wives do not expect to be paid for their services but evangelists should show tokens of appreciation.

One pastor's wife narrated her frustration at the evangelist's inability to show appreciation for her services. This evangelist never extended any token of appreciation to her and she did not know what arrangement the evangelist had made with her husband for all the services which she gave. However, whenever the evangelist went for visitation accompanied by some local female church members he would buy them small tokens, including ice cream or soft drinks, in appreciation for their services. Each time these people narrated how good and caring the evangelist was, the wife's heart would sink, for she never got any token from this evangelist until the crusade was over. It pained her to have her friends show her the tokens of appreciation yet she did not receive even a Bible. There is need for evangelists to be careful to show appreciation for the hospitality of the women taking care of them.

\section{Cultural Aspects of Sermons}

The evangelist in Russia can take advantage of a rich Christian cultural inheritance. For example, the Russian Orthodox Church places a lot of emphasis on the Ten Commandments. These are posted on the door at the entrance of all Orthodox 
Churches. The majority of elderly Orthodox Church members have memorized these commandments and can easily recite them, including the fourth commandment on the Sabbath. The evangelist should use such cultural points on which to build his sermons. Another cultural heritage, of which the evangelist should take advantage in his sermons, is baptism. The Orthodox Church believes in baptism, specifically child baptism. The orthodox Church celebrates the baptism of Jesus, so this cultural practice could effectively be used by the evangelist to present a strong case for baptism and secure commitments for baptism.

\section{Order and Content of Sermons}

All evangelistic sermons should be Christ-centered. The evangelist should ensure that the first few sermons are designed to build up the audience's confidence and establish the Bible as God's book to modern man. Most evangelists in Russia start their crusades very well and present messages that attract the audience. The main weakness which foreign evangelists in Russia should avoid is that of using the traditional Western order of sermon topics, which is good only for countries which have a long-time Protestant background, with most people already knowing about Jesus. Sermons targeted at people coming from a Protestant background require an emphasis on doctrines with a major objective of helping people realize that this is the true church. This is not the setting in Russia today. Evangelists need reorientation. Russia has been 
without a Bible for seventy years. Evangelists should understand what that means to sermon titles and the order of sermons. It is important for the evangelist to give logical reasons why the Bible is God's Book, with strong support for these arguments from science, archaeology, and history.

The second emphasis is on who Jesus is. In the traditional SDA evangelistic sermon approach, every topic may have a Christcentered approach but, with only one or two sermons about the birth, life, death, and resurrection of Jesus. This approach is not appropriate for Russian people who want to know who Jesus is. People want to know how He was born and how He grew up. People want to know what He did and how He lived, and all about the plan of salvation. In most countries the stories about Jesus are familiar to many people, as they get these stories in Sunday School, homes, and schools. This is not so in Russia. The evangelist should plan more sermons about Jesus. Doctrinal coverage should not be the main thrust to be accomplished in three to four weeks of the crusade. After the audience has heard about Jesus, they can be told about what Jesus expects of them in terms of doctrines. The seventy years of persecution and suffering have created such a deep love for Jesus Christ in the minds of Russian people that the evangelist must talk more of the love of Jesus Christ. 
CHAPTER V

SUMMARY, CONCLUSION, AND RECOMMENDATIONS

\section{Summary}

This study is a descriptive analysis of John Carter's 1992 evangelistic campaign analyzed with the aim of suggesting long-term results from public campaigns. The impact of public evangelism on church-growth trends and subsequent backsliding were analyzed. It was found that high rates of church growth were usually accompanied by high rates of backsliding. Specific findings relate to two areas: local church empowerment and baptismal preparation.

\section{Local Church Empowerment}

1. During the pre-evangelism phase a golden opportunity to empower the church was lost as the Conference officials monopolized all the organizational aspects of the pre-evangelism phase. The local church members were mere spectators receiving instructions from the Conference office.

2. During the crusade the local church did not have any decision-making role, as all decisions were taken by the evangelist and his team. The local church was not made a part of the daily visitation schedule as even this was monopolized by the evangelistic team. 
3. After the crusade no specific plans were made to involve the local church in a properly designed and coordinated follow-up so that baptized members would be assimilated by the local church.

4. Specific action plans were not adopted by the local church, nor was the local church given specific duties and responsibilities.

5. A monitoring mechanism could have helped the local pastor be more accountable.

\section{Preparation of Baptism Candidates}

1. Constraints of time, place, and shortage of resource persons had a great effect on efforts to prepare baptismal candidates.

2. Plans for Bible classes, which should have occurred both before and after baptism, failed to materialize and unforeseen problems resulted.

3. Responsible laypersons needed to be trained to help the few pastors in their efforts to prepare the many new interests.

4. It was risky to conduct a baptism for people who had heard the gospel for only five or six weeks without an individual assessment of their understanding of the gospel.

5. Carter's efforts to establish and build two large churches for the new converts, as well as sponsoring training of new pastors, were a long-term strategy towards preparation of 
baptismal candidates, but this did not meet the immediate needs of the new converts.

\section{Conclusion}

The unique sociocultural and political heritage of Russia requires the development of a specific Russian strategy for public evangelism. The current traditional SDA model of public evangelism introduced by foreign evangelists is not appropriate for the Russian setting, because of the following factors:

1. Open public evangelism is a new phenomenon in Russia.

2. The laity remain as spectators as they have not been trained to play their roles, which are critical for the success of public evangelism.

3. The Russian Orthodox Church is threatened by the highpressure public evangelism strategies and is developing counterattacks to regain its lost glory.

4. Open public evangelism designed from a Protestant model is a reaping activity covering five or six weeks and yet Russia, deprived of the Bible for seventy years, requires a combination of sowing and reaping activities, which take much longer.

5. The traditional model of public evangelism needs to be adapted for Russia because the emphasis of the sermons is doctrinal, which is the main issue in Protestantism; in Russia, atheism is the main issue. Therefore, more emphasis must be given to telling about Jesus and the great plan of salvation. 
6. In Russia far more care is needed in preparing people for baptism.

\section{Field Schools}

Most of the evangelists coming from a Western Protestant background have taken too much for granted when conducting crusades in Russia or conducting field schools of public evangelism. In view of the problems connected with the traditional SDA evangelists' procedures, I offer. the following steps for a Russian model:

1. A field school of evangelism should include training on how to handle opposition from the Russian Orthodox Church.

2. Role clarification during public evangelism is a crucial topic for all those taking part in a field school of evangelism to avoid role confusion among pastors, church administrators, and lay members.

3. The role of pastors during all three evangelism phases is often limited by lack of wide experience in public evangelism. These limitations call for close monitoring of all the activities by the evangelist without taking anything for granted.

\section{Three Phases of Evangelism}

A well-defined process of public evangelism consisting of the pre-evangelism phase, conducting of the crusade, and postevangelism phase should make maximum use of the local laity. Each of the three phases should take into consideration the 
unique sociocultural features of Russia if the high backsliding trends are to be reversed.

The following considerations are critical for a successful crusade :

During the Pre-evangelism Phase

1. Carry out needs assessment of target group and implement programs to meet these needs.

2. Design and implement a systematic visitation program involving local church members.

3. Demonstrate and publicize the church's concern for the targeted local community.

4. Seek to build bridges with leaders at all levels of the community, including the orthodox Church.

5. Start a Bible correspondence school in the targeted city.

Through radio advertisements for Bible correspondence courses, blanket the town so that interested persons may be enrolled in the courses. Thus they will better prepare themselves for the evangelistic series.

\section{During the Crusade}

1. The crusade staff and preacher should not offend the culture of the people and should use preachers' gowns.

2. Music as a special feature of the Russian culture should be used extensively during the crusade. 
3. The sermons preached should be sensitive to the Russian culture so as not to create a perception of either superiority or inferiority of the Russian culture.

4. Cultural practices which may not have any biblical basis (e.g., prayer posture in Russia) should be respected by the preacher.

5. Evangelists should show respect to other churches, including the orthodox Church, without compromising the message.

Post-evangelism Phase

1. Analyze the types of people who join the church.

2. Use the results of the analysis to establish small groups.

3. Make an effort to create opportunities for the utilization of talents and gifts of the new members coming to the church.

4. Study the special needs of youth and create special programs for their welfare.

\section{Recommendations}

In view of the findings from this study it is recommended that:

1. Division-wide guidelines for all foreign and local evangelists working in Russia should be developed and made available so that there will be no confusion regarding procedures. 
2. Every evangelist in Russia should make a personal effort to empower the local church to own the crusade by initiating revival and teaching a proper concept of evangelism during the pre-evangelism phase.

3. Every evangelist should ensure that adequate resources are allocated towards support of the follow-up phase of the crusade in order to facilitate and assimilate new converts.

4. Foreign evangelists should seek familiarity with basic cultural practices and values so that they will not unintentionally offend people attending the meetings.

5. The sermon outlines for Russian evangelistic crusades should be different from the traditional western model designed for a largely Protestant audience and should include several sermons about Jesus.

6. Evangelists should ensure proper utilization of financial resources during the pre-evangelism phase to avoid any appearance of impropriety and possible mishandling of funds that could be constructed as unethical or even dishonest. The local church must implement an accountability structure that is open to inspection.

7. All pastors in Russia should be trained how to conduct evangelistic crusades.

8. A training curriculum for public evangelism should be developed, taking into consideration the unique sociocultural and political heritage of Russia. The curriculum should be made 
available to evangelists who desire to conduct a field school of evangelism as one of their crusade programs.

In order to facilitate implementation of this strategy of public evangelism the following should be done:

1. All unions should organize and sponsor workshops for pastors, in which the critical elements of a Russian public evangelism strategy can be identified and discussed. The Union Public Evangelism Director should be empowered to conduct such workshops and seminars.

2. The seminary should facilitate change by training pastors in a new strategy of Public Evangelism and by developing support materials such as slides and films.

3. The Conference directors should encourage foreign evangelists to mobilize adequate resources towards expenses of follow-up as a critical expense for the success of the crusade.

\section{Recommendation to the General Conference and} Division Ministerial Departments

That if, in the future, China or other closed countries open, I suggest the following:

1. A Cultural Sensitivity orientation be provided for all evangelists.

2. A required reading list of books and articles dealing with cultural areas that impact evangelism should be developed. 3. A cultural-specific school of evangelism curriculum guide should be developed and given to all evangelists who wish 
to conduct schools of evangelism as part of their crusade.

4. A consultant in Public Evangelism should be assigned to study and document cultural factors among target audiences so that evangelists can use such information as guidelines.

5. Ensure that all foreign evangelists targeting areas such as Russia, China, India, etc., are informed and supplied with relevant information and guidelines.

6. An understanding of differences between evangelistic audiences in home countries and target countries in areas such as (a) biblical background and understanding and (b) knowledge of plan of salvation, etc., should be fostered.

7. Realizing that in many closed countries pastors are in short supply, evangelistic budgets must be divided and shared to allow adequate post crusade follow-up so we do not have a repeat of the Russian experience with 40-60\% apostasy rates.

8. Facilitate strengthening of follow-up programs by developing culturally specific youth programs and materials with the help of consultants in public evangelism, General Conference youth directors, and the youth director of the targeted division.

9. Help each division develop a special curriculum guide for small group (people-group approach), which can be used in a follow-up program.

\section{For Further study}

Areas that would profit from further study are the following: 
1. A study of backsliders from major evangelists such as Carter, to analyze their perceptions in an effort to design better follow-up programs

2. A comparative analysis between John Carter's and Mark Finley's public evangelism efforts in Russia

3. A study of the problems faced by Russian pastors who have conducted evangelistic crusades after undergoing field schools of evangelism conducted by major foreign evangelists, in order to develop a unique public evangelism training curriculum. 


\section{BIBLIOGRAPHY}

Aldrich, Joseph C. Life-Style Evangelism. Portland, OR: Multnomah Press, 1981.

Anderson, Clifford R. "Let's Capitalize on Health." Ministry, June 1995, 19.

Anderson, Roy Allan. The Shepherd Evangelist. Washington, DC: Review and Herald Publishing Association, 1950.

Barna, George. Marketing the Church. Colorado Springs, Co: NavPress, 1993.

Bauman, Harold E. "Goals of Church Growth." In Mission Evangelism and Church Growth, ed. Norman Kraus, 140-142. New York: Herald Press, 1980.

Beach, B. B. "The Church Under Communism." Adventist Review, October 9, 1986, 9-10.

Berg, Orley. The Work of the Pastor. Nashville, TN: Southern Publishing Association, 1966.

Bernardino, Dominic. "Prayer-The Missing Element in Evangelism." In Evangelizing Adults, ed. Glenn C. Smith, 323-327. Wheaton, IL: Tyndale House Publishers, 1985.

Bourdeaux, Michael. Opium of the People. New York: Bobbs-Mine Company, 1966.

Calver, Clive, Derek Copley, Bob Moffett, and Jim Smith. A Guide to Evangelism. London: Marshall, Morgan and Scott, 1984 .

Cerna, Miguel Angel. "Win Them and Hold Them." Ministry, December 1993, 24.

Chamberlin, Cindy. "Operation Bearhug Reaches across Pacific." Adventist Review, November 19, 1992, 20.

Conradi, L. R. "A Visit to Russia." In Historical Sketches of the Foreign Missions of the Seventh-day Adventists, 250-271. Basle: Imprimerie Polygotte, 1986. 
Cross, C. G. "Our Missionary Program for the Blind and Visually Handicapped." Ministry, July 1964, 4-5.

Dayton, Edward R., and David A. Fraser. Planning Strategies for World Evangelism. Grand Rapids, MI: William Eerdmans Publishing, 1980 .

Dudley, Roger L., and Des Cummings. Adventures in Church Growth. Washington, DC: Review and Herald Publishing Association, 1983 .

Edwards, Lovett. Russia and Her Neighbours. Oxford: University Press, 1968 .

Edwards, Rex D. "Baptism and Conversion." Ministry, August $1993,11$.

Ehlers, Robert S., Fred Schulze, Ann C. Bigelow, and Gordon Livermore. The USSR Today: Perspectives from the Soviet Press. Columbus, $\mathrm{OH}$ : Current Digest of the Soviet Press, 1988 .

Enright, Merrill L. "Music in the Evangelistic Worship Service." Ministry, January 1955, 38-39.

Fay, Jocelyn. "Preparation for the Session." Adventist Review, April 17, 1980, 3.

Fisher, C. William. Evangelistic Moods, Methods, and Messages. Kansas City, MO: Beacon Hall Press, 1967.

Fly, James I. "The Day in Review." Adventist Review, July 5, 1985,2 .

Fowler, Thom W. "The Church and Evangelism." M.Div. Project, Andrews University, 1974.

Frame, Robert R. "Ellen White and Public Evangelism in Australia." Ministry, August 1975, 8.

Gesswein, Armin R. "Prayer and Evangelism." In Evangelism, the Next Ten Years, ed. Sherwood Elienwirt, Waco, TX: Word Books Publishers, 1978, 90-95.

Green, Michael. "Evangelism." Ministry, January 1993, 12-15.

Grunlan, Stephen A., and Marvin K. Mayers. Cultural Anthropology: A Christian Perspective. Grand Rapids, MI: Zondervan Publishing House, 1988. 
Guild, Daniel R. "Adventist Radio Blankets Former Soviet Union." Adventist Review, December 31, 1992, 21-22.

. "Meetings Triple Membership in St. Petersburg." Adventist Review, March 19, 1992, 19-20.

Gunther, John. Inside Russia Today. New York: Harper and Brothers, 1957 .

Halvorsen, Ron. "Evangelism: Getting the Church Ready." Ministry, January 1993, 16-18.

Hedlund, Roger E. The Mission of the Church in the World. Madras: Evangelical Literature Service, 1985.

Hegstad, R. R. "The Day in Vienna." Review and Herald, July 13, 1975,2 . . "Challenge A+." Liberty, March/April 1991, 9-13.

Hiebert, Paul G. Anthropological Insights for Missionaries. Grand Rapids, MI: Baker Book House, 1983.

Howell, E. E. The Great Advent Movement. Washington, DC: Review and Herald Publishing Association, 1935.

Hunt, Lionell A. Mass Child Evangelism. Chicago: Moody Press, 1951.

Institut Perevoda Biblii. S Dobroi Vestiu k Svoim Sootechestvennikam (With good news to our compatriots). Zaokskii: Institut Perevoda Biblii, 1996.

Ivanova, Natasha. "Four Years without Holidays." Adventist Review, Special Issue, June 1995, 20.

Jackson, Andrew. A Heart for Others. Seattle: YWAM Publishing, 1992 .

Johnsson, William G. "Mission, Keynotes Annual Council." Adventist Review, November 12, 1981, 4.

"The Risen Christ over Red Square." Adventist Review, June 18, 1992, 15 .

- Carlos Medley, and Myron K. Widmer. "Spring Meeting Approves New Division, Higher Wages." Adventist Review, April 20, 1989, 6-7. 
Johnstone, Patrick J. Operation Russia. London: OM Publishing, 1993.

Jules, Abraham J. "Seven Secrets of Successful Evangelism." Ministry, February 1996, 15.

Kane, Herbert. Christian Missions in Biblical Perspective. Grand Rapids, MI: Baker Book House, 1976.

Kangas, Janet. "Mission Outreach Spurs Local Church Growth." Adventist Review, November 12, 1992, 21.

Kleuser, C. Louise. The Bible Instructor. Washington, DC: Review and Herald Publishing Association, 1949.

Kneeling Christian, The. Madras: Gospel Literature, 1980.

Kuhne, Gary. "Follow-up: An Overview." In Discipleship, ed. B. Hanks and W. Sheel, 110-114. Grand Rapids, MI: Zondervan Publishing House, 1982 .

Kulakov, M. P. "Bright Prospects in the USSR." Adventist Review, July 12, 1990, 22-24.

Kulakov, Mikhail. God's Soviet Miracles. Boise, ID: Pacific Press Publishing Association, 1993.

Lappo, G. M., redactor. Goroda Rossii, Entsiklopedia (Encyclopaedia of the cities of Russia). Moskva: Nauchnoe Izdatelstvo, 1994.

Lingenfelter, Sherwood G. Transforming Culture: A Challenge for Christian Mission. Grand Rapids, MI: Baker Book House, 1995.

Lohne, Alf. Adventists in Russia. Hagerstown, MD: Review and Herald Publishing Association, 1987.

. "Siberian Believers Flock to Spiritual Meeting." Adventist Review, September 26, 1985, 20-22.

Loughborough, J. N. The Great Second Advent Movement: Its Rise and Progress. Washington, DC: Review and Herald Publishing Association, 1903.

Lyrene, Edward C., Jr. "Prayer and Evangelism." In Evangelism in the Twenty-first Century, ed. Thom S. Rainer, 89-102. Wheaton, IL: Harold Shaw Publishers, 1989. 
Manilich, E. "Annual Report of Western Russian Union Conference Session." Moskva, Western Russian Union, November 26-28, $1996,5-6$.

McCartby, Jerome, and William D. Perreault. Basic Marketing. Boston: Irwin, 1990.

McGavran, Donald A. Understanding Church Growth. Grand Rapids, MI: William B. Eerdmans Publishing Company, 1980.

Medley, Carlos. "Breakthrough in the USSR." Adventist Review, August 7, 1986, 6-8.

- "Soviet Leader Visits GC." Adventist Review, November $13,1986,6-7$.

Morar, Michael. "Structured Interview with Russian Pastors and SDA Church Members." Moskva, Western Russian Union, December 1996.

Mueller, Konrad. "Redeeming the Past." Adventist Review, March $30,1995,18-19$.

Naden, Roy. "The Holy Spirit and Evangelism." Ministry, March 1993,8 .

New Encyclopaedia Britannica, The. Chicago: Encyclopaedia Britannica, 1991. S.V. "Gorky."

Newman, David, and Sharon Cress. "Super Evangelism in Moscow." Ministry, November 1993, 15.

Ng, G. T. "Adventist Youth in Asia-Pacific: Orphans in the Church." Youth Ministry, 5, no. 122, 1995, 25.

Otis, Rose. "Adventist Church Dedicates First Seminary in UsSR." Adventist Review, February 16, 1989, 6 .

Parashuk, E. "Report of $2^{\text {nd }}$ Meeting of Volgo Vatsky Conference." Nizniy Novgorod, Volgo Vatsky Conference, January 9-11, 1997.

Ponraj, S. D. Church Planting Guide. Lalgarh, Madhupur, Bihar: Mission Educational Books, 1995.

Reimer, Johannes. Operation Soviet Union: How to Pray for 160 People Groups in the USSR. Fresno, CA: Logos, 1990. 
Richards, Lawrence O. Youth Ministry. Grand Rapids, MI: Zondervan Publishing House, 1972.

Rieber, Alfred J., and Robert C. Nelson. A Study of the USSR and Communism: An Historical Approach. Chicago: Scott Foresman and Company, 1962 .

Rock, Calvin B. "Meetings Reap Nearly 1000." Adventist Review, January $28,1993,22$.

Sahlin, Monte. "Friendship Evangelism." Ministry, September $1993,8$. . "Where Are Our Missing Members?" Ministry, May 1989, 18.

Sanders, Oswald J. Effective Evangelism. Grand Rapids, MI: Christian Focus Publications, 1982.

Savage, Peter. The New Face of Evangelism. Downers Grove, IL: InterVarsity Press, 1976.

Schantz, Borge. "A Western Message in Eastern Europe." Ministry, November 1993, 8 .

Schuller, Lyle S. Activating the Passive Church. Nashville, TN: Abingdon Press, 1981.

Southard, Samuel. Pastoral Evangelism. Nashville, TN: Broadman Press, 1962.

Spalding, A. W. Captains of the Host. Washington, DC: Review and Herald Publishing Association, 1949.

- Origin and History of Seventh-day Adventists. Washington, DC: Review and Herald Publishing Association, 1962 .

Spangler, J. R. "Thousands Turn from Communism to Christ." Adventist Review, June 4, 1992, 27-28.

- "The Soviet Union: A Decade of Destiny." Adventist Review, February 7, 1991, 8-10.

Stele, Galina I. "An Analysis of Growth in the Euro-Asia Division (1985-1995) Leading to a Strategy for Developing Home Churches." D.Min. dissertation, Andrews University, Berrien Springs, MI, 1996. 
Stepanov, V. Svidetelstvo Obvinenija (The testimony of

Accusation). Moskva: Russkoe Knigoizdatelstvo

Tovarishestvo, 1993.

Taylor, Charles R. "Making Up for Lost Time." Adventist Review, December 22, 1994, 18-20.

Teppone, V. V. Iz Istorii, Tzerkvi (From history of the church). Kaliningard: Yantarnij Skaz, 1993.

Thompson, R. A. "Coordinated Evangelism." Ministry, September 1970,40 .

Thompson, Ralph G. "It's Beginning to Rain." Adventist Review, July 8, 1990, 12 .

Thomsen, Marilyn. "The Gospel Opens Door of an Isolated City." Adventist Review, August 20, 1992, 6 .

Vandeman, George. "The Short Campaign." Ministry, September $1995,26$.

Vernadsky, George. A History of Russia. New Haven, CT: Yale University Press, 1929.

Warren, Rick. The Purpose Driven Church. Grand Rapids, MI: Zondervan Publishing House, 1995.

White, Ellen G. Counsels on Health. Washington, DC: Review and Herald Publishing Association, 1946.

- Education. Nashville, TN: Southern Publishing Association, 1923 .

- Evangelism. Washington, DC: Review and Herald Publishing Association, 1946.

- Gospel Workers. Washington, DC: Review and Herald Publishing Association, 1948.

- Life Sketches of Ellen G. White. Mountain View, CA: Pacific Press Publishing Association, 1943.

- Patriarchs and Prophets. Mountain View; CA: Pacific Press Publishing Association, 1958.

- Testimonies for the Church. 9 vols. Washington, DC: Review and Herald Publishing Association, 1948. 
- Testimonies to Ministers. Boise, ID: Pacific Press Publishing Association, 1962.

- to Brethren in Norway. Letter 14, 1887. Ellen G. White Center, Spicer Memorial College, Pune, India.

Wick, Paul Borth. Organizing Your Youth Ministry. Grand Rapids, MI: Zondervan Publishing House, 1988.

Wilson, Ted N. C. "God's Miraculous Power in the Euro-Asia Division." Adventist Review, July 7, 1995, 5-7.

Wilson, T. W. "Crusade Evangelism." In Evangelism in the TwentyFirst Century, ed. Thom S. Rainer, 170-173. Wheaton, IL: Harold Shaw Publishers, 1989.

Wood, Maurice A. P. "Lay Training for Evangelism." In Evangelism: The Next Ten Years, ed. Sherwood Elion Wirt, 84-87, Waco, TX: Word Books Publisher, 1978.

Woolsey, Raymond H. Evangelism Handbook. Washington, DC: Review and Herald Publishing Association, 1972.

Year Book of the Seventh-day Adventist Denomination. Washington, DC: Review and Herald Publishing Association, 1924.

Zuev, U. P. o Svobode Sovesti, Veroispovedanii i Religioznoih objedinenijah (Freedom of conscience, denominations and religious unions). Moskva: Mezhdunarodnaya Assotsiatsia Religioznoi Svobodi, Rossiiskoe otdelenie, 1996. 
Personal Family Background

Name

Place of Birth

Date of Birth

Home Address
Mikhail K. Morar

Novo-Ivanovca, Kotovsk Region Moldova, USSR

May 7, 1952

Tula City, Furmonova str. No. 10 Russia

\section{Educational Background}

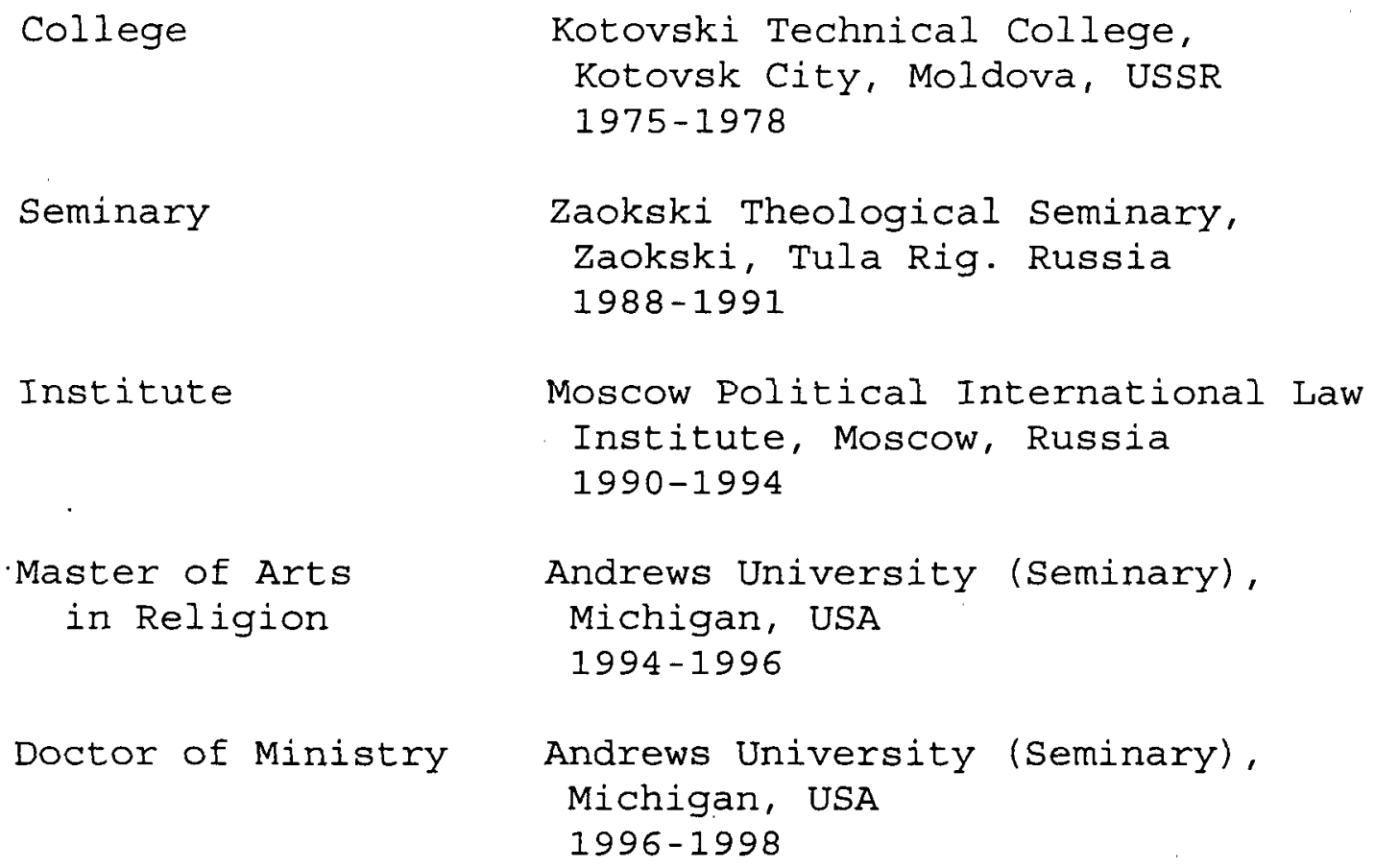

Work Experience

Associate Pastor

SDA Church, Berdeansk city, Zaporozhie Region, Ukraine 1978-1979

Associate Pastor

SDA Church, Krivoy - Rog City, Dnepropetrovsk Region, Ukraine 1979-1981 
Technical Secretary of the President of SDA Church in USSR

Construction

Purchasing officer

Assistant of

Director of

Publishing

Department of

the Euro-Asia

Division

Director of

Publishing

Department

Director of Global Mission and

Evangelism

Evangelist

Director of Global Mission and

Evangelism
SDA Church in USSR

Tula City, Russia 1981-1987

Zaokski Theological Seminary Zaoksk, Tula Region, Russia 1987-1989

Euro-Asia Division, Zaoksk, Tula Region, Russia 1989-1990

Russian Union Conference, Tula City, Russia. 1992-1994

Volga-Vatsky Conference, Nizhniy Novgorod, Russia $1994-1996$

Volga-Vatsky Conference, Nizhniy Novgorod, Russia 1996 to present 